ORNL-6864

\title{
WASTE MANAGEMENT \\ PROGRAMMATIC ENVIRONMENTAL IMPACT STATEMENT METHODOLOGY FOR ESTIMATING HUMAN HEALTH RISKS
}

Prepared for

The United States Department of Energy

in preparation for the

Programmatic Environmental Impact Statement

Prepared by

RECEIVED

JUL 104997

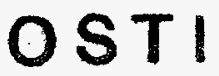

Center for Risk Management

Oak Ridge National Laboratory ${ }^{1^{*}}$

University of Tennessee ${ }^{2}$

Office of Environmental Compliance and Documentation ${ }^{3}$

Midwest Technical, Inc. ${ }^{4}$

Bruce Bergenback ${ }^{4}$

Bonnie P. Blaylock ${ }^{1}$

Janice L. Legg ${ }^{1}$

Patricia Pehlman ${ }^{1}$

Ray Phillippi ${ }^{2}$

Pam Ratledge ${ }^{1}$

Pat A. Scofield ${ }^{3}$

Mary Ann Simek ${ }^{2}$

Cynthia Smith ${ }^{4}$

Curtis C. Travis ${ }^{1}$

David Wollert ${ }^{2}$

May 1995

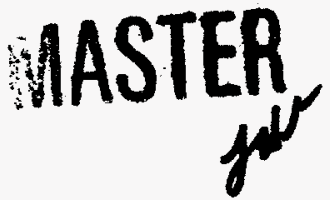

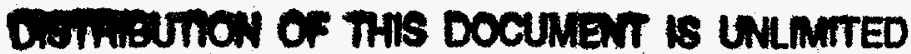

"Managed by Martin Marietta Energy Systems, Inc., for the U.S. Department of Energy under contract no. DE-AC05-840R21400. 


\section{DISCLAIMER}

This report was prepared as an account of work sponsored by an agency of the United States Government. Neither the United States Government nor any agency thereof, nor any of their employees, makes any warranty, express or implied, or assumes any legal liability or responsibility for the accuracy, completeness, or usefulness of any information, apparatus, product, or process disclosed, or represents that its use would not infringe privately owned rights. Reference herein to any specific commercial product, process, or service by trade name, trademark, manufacturer, or otherwise does not necessarily constitute or imply its endorsement, recommendation, or favoring by the United States Government or any agency thereof. The views and opinions of authors expressed herein do not necessarily state or reflect those of the United States Government or any agency thereof. 


\section{DISCLAIMER}

Portions of this document may be illegible electronic image products. Images are produced from the best available original document. 


\title{
WASTE MANAGEMENT \\ PROGRAMMATIC ENVIRONMENTAL IMPACT STATEMENT METHODOLOGY FOR ESTIMATING HUMAN HEALTH RISKS
}

Prepared for

The United States Department of Energy

in preparation for the

Programmatic Environmental Impact Statement

\author{
Prepared by \\ Center for Risk Management \\ Oak Ridge National Laboratory ${ }^{1 *}$ \\ University of Tennessee ${ }^{2}$ \\ Office of Environmental Compliance and Documentation ${ }^{3}$ \\ Midwest Technical, Inc. ${ }^{4}$
}

Bruce Bergenback ${ }^{4}$

Bonnie P. Blaylock

Janice L. Legg ${ }^{1}$

Patricia Pehlman ${ }^{1}$

Ray Phillippi ${ }^{2}$

Pam Ratledge ${ }^{1}$

Pat A. Scofield ${ }^{3}$

Mary Ann Simek ${ }^{2}$

Cynthia Smith ${ }^{4}$

Curtis C. Travis ${ }^{1}$

David Wollert ${ }^{2}$

The subrritted manuscript has been authored by a confractor of the U.S. Government under contract No. DEACO5-84OR2 1400. Accordingly. the U.S.

Government retains a nonexclusive,

royatty-free ticense to publish or reproduce

the putished form of this contribution, or

the published torm of this US. Government

animeace"

May 1995

\footnotetext{
"Managed by Martin Marietta Energy Systems, Inc., for the U.S. Department of Energy under contract no. DE-AC05-840R21400.
} 


\section{CONTENTS}

CONTENTS $\ldots \ldots \ldots \ldots \ldots \ldots \ldots \ldots \ldots \ldots \ldots \ldots \ldots \ldots \ldots \ldots \ldots \ldots \ldots$

FIGURES $\ldots \ldots \ldots \ldots \ldots \ldots \ldots \ldots \ldots \ldots \ldots \ldots \ldots \ldots \ldots \ldots \ldots \ldots$

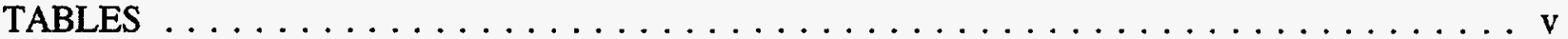

ACRONYMS $\ldots \ldots \ldots \ldots \ldots \ldots \ldots \ldots \ldots \ldots \ldots \ldots \ldots \ldots \ldots \ldots \ldots \ldots \ldots \ldots \ldots$

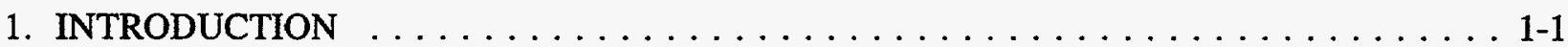

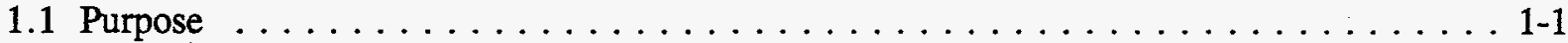

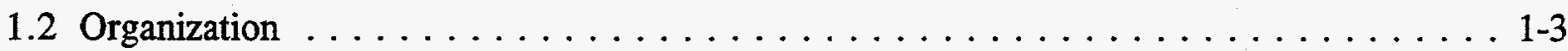

2. WASTE MANAGEMENT METHODOLOGY: OFFSITE AND NONINVOLVED WORKER

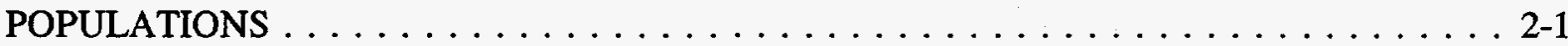

2.1 Characterization of the Environmental Setting $\ldots \ldots \ldots \ldots \ldots \ldots \ldots \ldots \ldots \ldots$

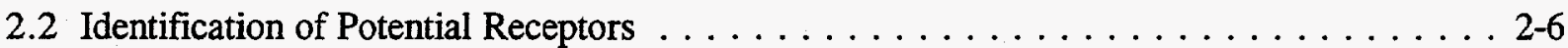

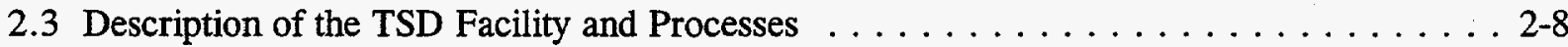

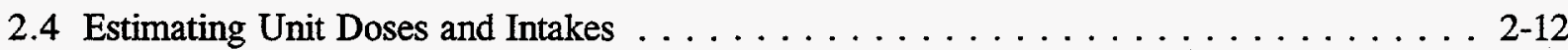

2.4.1 Contaminant Releases to Groundwater . . . . . . . . . . . . . . . . . 2-13

2.4.2 Radionuclide Releases to Air . . . . . . . . . . . . . . . 2-15

2.4.3 Chemical Releases to Air . . . . . . . . . . . . . . . . . . . . 2-17

2.4.4 Exposure to Soil/Contaminated Drilling Waste $\ldots \ldots \ldots \ldots \ldots$. . . . . . . .

2.5 Estimating Total Installation Risk . . . . . . . . . . . . . . . 2-18

2.6 Estimating Risk for WM Alternatives . . . . . . . . . . . . . . . . . . . . . 2-19

2.7 Assumptions And Uncertainties . . . . . . . . . . . . . . . . . . . . 2-19

2.7.1 Model Uncertainties . . . . . . . . . . . . . . . . . . . . . . 2-20

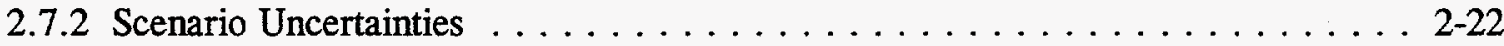

2.7.3 Parameter Uncertainties . . . . . . . . . . . . . . . . . . 2-22

3. WASTE MANAGEMENT METHODOLOGY: WM WORKERS . . . . . . . . . . . . 3-1

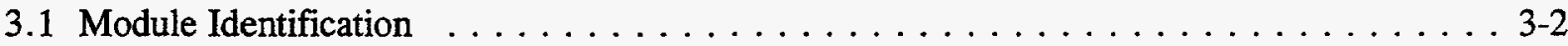

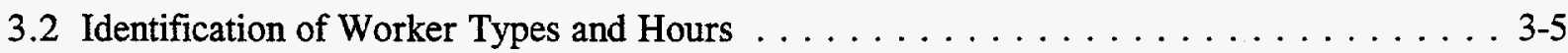

3.3 Estimation of Doses and Intakes: Inhalation $\ldots \ldots \ldots \ldots \ldots \ldots \ldots \ldots \ldots \ldots \ldots$

3.3.1 Air Concentrations . . . . . . . . . . . . . . . . . . . .

3.3.2 Intakes and Doses . . . . . . . . . . . . . . . . . . . . . . 3-8

3.4 Estimation of Doses: Direct Radiation $\ldots \ldots \ldots \ldots \ldots \ldots \ldots \ldots \ldots \ldots \ldots$

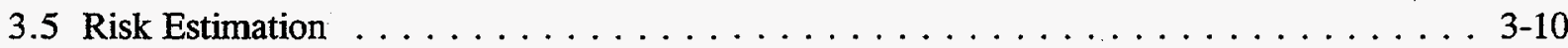

3.5.1 Risks From Exposure To Contaminants . . . . . . . . . . . . . 3-10

3.5.2 Risks From Physical Trauma . . . . . . . . . . . . . . . 3-12

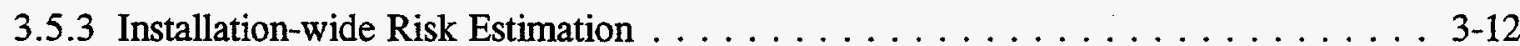

3.6 Nonroutine Event Scenarios . . . . . . . . . . . . . . . . . . . . . . 3-12

3.6.1 Operational Nonroutine Events $\ldots \ldots \ldots \ldots \ldots \ldots \ldots \ldots \ldots \ldots \ldots \ldots . \ldots \ldots$ 
3.6.2 Waste Handling Nonroutine Events . . . . . . . . . . . . . 3-13

3.6 .3 External Events . . . . . . . . . . . . . . . . . . . . 3-14

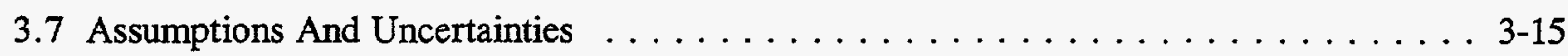

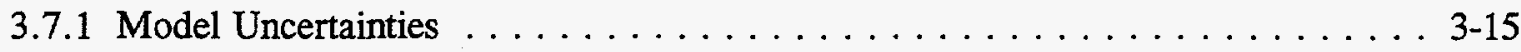

3.7 .2 Scenario Uncertainties . . . . . . . . . . . . . . . . . . 3-16

3.7 .3 Parameter Uncertainties . . . . . . . . . . . . . . . . . 3-16

A. WASTE MANAGEMENT WORKER ACTIVITIES AND MODULES $\ldots \ldots \ldots \ldots \ldots$. . . A-1

A.1 Treatment Trains: Modular Approach $\ldots \ldots \ldots \ldots \ldots \ldots \ldots \ldots \ldots$. . . . . . .

A.2 WM Worker Environment and Worker Types . . . . . . . . . . . . A A-3

A.3 Waste Management Modules . . . . . . . . . . . . . . . . . A A-4

A.3.1 Receiving/Inspection $\ldots \ldots \ldots \ldots \ldots \ldots \ldots \ldots \ldots \ldots \ldots \ldots \ldots$

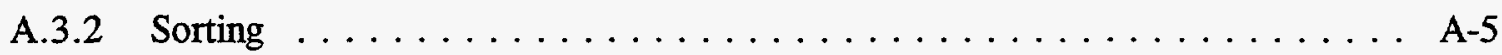

A.3.3 Size Reduction (Shredding) $\ldots \ldots \ldots \ldots \ldots \ldots \ldots \ldots \ldots \ldots \ldots \ldots$

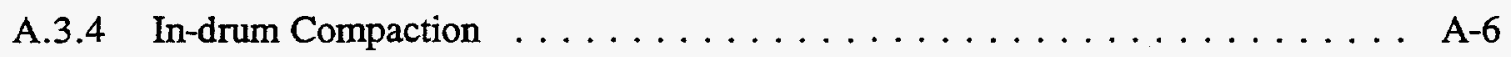

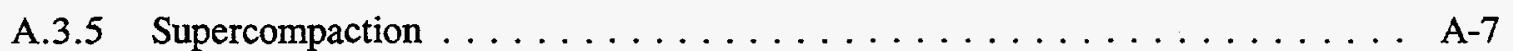

A.3.6 Shredding/Compaction $\ldots \ldots \ldots \ldots \ldots \ldots \ldots \ldots \ldots \ldots \ldots \ldots \ldots$

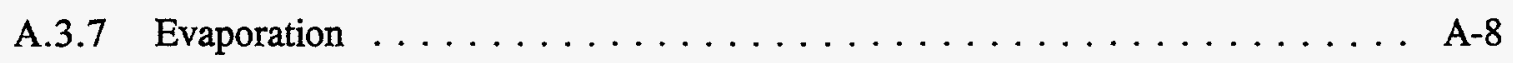

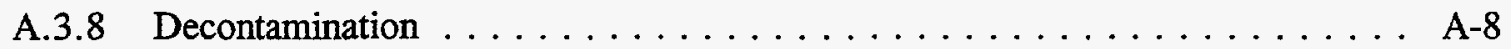

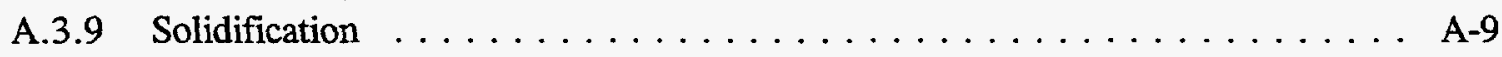

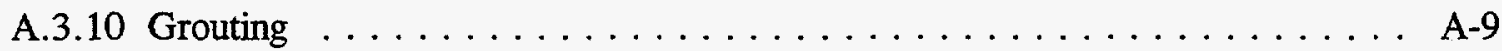

A.3.11 General Aqueous Treatment . . . . . . . . . . . . . . A-10

A.3.12 Neutralization . . . . . . . . . . . . . . . . A-11

A.3.13 Ion Exchange $\ldots \ldots \ldots \ldots \ldots \ldots \ldots \ldots \ldots \ldots \ldots \ldots \ldots \ldots$

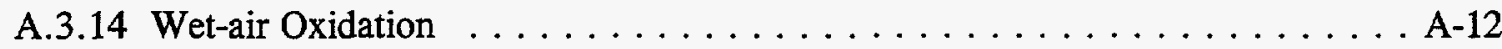

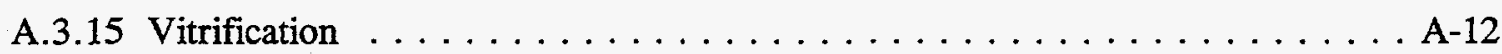

A.3.16 Incineration $\ldots \ldots \ldots \ldots \ldots \ldots \ldots \ldots \ldots \ldots \ldots \ldots \ldots \ldots \ldots \ldots \ldots \ldots \ldots .13$

A.3-17 Metal Melting . . . . . . . . . . . . . . . A A-13

A.3.18 Thermal Desorption . . . . . . . . . . . . . . . . . . A-14

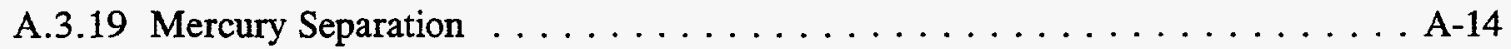

A.3.20 Lead Recovery $\ldots \ldots \ldots \ldots \ldots \ldots \ldots \ldots \ldots \ldots \ldots$ A-15

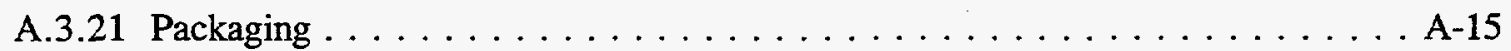

A.3.22 Reactive Metals Recovery . . . . . . . . . . . . . . A A-15

A.3.23 Soil Washing . . . . . . . . . . . . . . . . . A-16

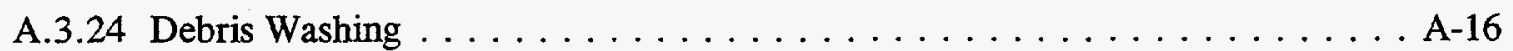

A.3.25 Sludge Washing . . . . . . . . . . . . . . . . A-17

A.3.26 Polymer Stabilization $\ldots \ldots \ldots \ldots \ldots \ldots \ldots \ldots \ldots \ldots \ldots$ A-17

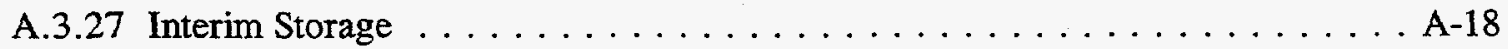

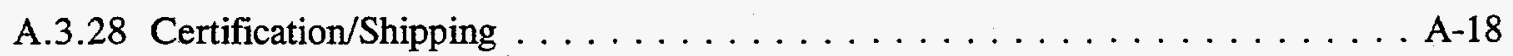

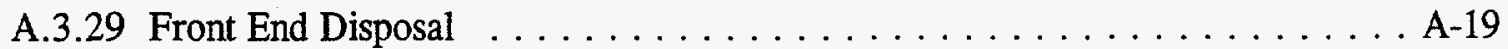

A.3.30 Shallow Land Burial . . . . . . . . . . . . . . . . . A-19

A.3.31 Tumulus Disposal $\ldots \ldots \ldots \ldots \ldots \ldots \ldots \ldots \ldots \ldots$ A $\ldots \ldots \ldots$ 
A.3.32 Below-ground Vault Disposal . . . . . . . . . . . . . . A-20

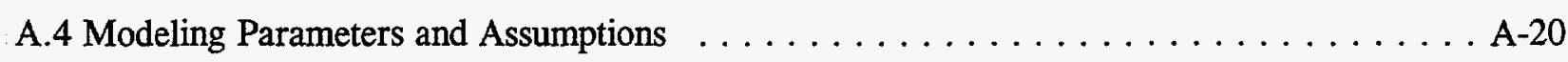

REFERENCES . . . . . . . . . . . . . . . . . . . . . R-1 


\section{FIGURES}

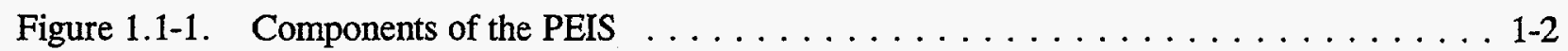

Figure 2-1. DOE Waste Management Installations Throughout the DOE Complex . . . . . . 2-1

Figure 2-2. Treatment, Storage and Disposal (TSD) Process . . . . . . . . . . . 2-3

Figure 2.3-1. Illustration of a Tumulus (Aboveground) Disposal Site . . . . . . . . . . . . . . 2-9

Figure 2.3-2. Illustration of a Shallow-land Burial Site $\ldots \ldots \ldots \ldots \ldots \ldots \ldots \ldots$

Figure 2.3-3. Illustration of a Below-ground Vault $\ldots \ldots \ldots \ldots \ldots \ldots \ldots \ldots \ldots \ldots$

Figure 2.4-1. Effective Stack Height $\ldots \ldots \ldots \ldots \ldots \ldots \ldots \ldots \ldots \ldots \ldots \ldots$

Figure $3.1-1$. Example WM Activities . . . . . . . . . . . . . . . . . $3-3$

Figure A.1-1. Conceptual Illustration of a Treatment Train $\ldots \ldots \ldots \ldots \ldots \ldots \ldots$. . . . .

Figure A.1-2. Illustration of a Waste Management Facility . . . . . . . . . . . A-2

Figure A.3-1. Conceptual In-drum Compactor Operation . . . . . . . . . . . . . A-7

Figure A.3-2. Illustration of a Typical Filtration Tank . . . . . . . . . . . A-11 


\section{TABLES}

Table 2-1. Summary of Conceptual Approach to Estimating Doses $\ldots \ldots \ldots \ldots \ldots .24$

Table 2.1-1. Transport Medium and Environmental Setting Characteristics $\ldots \ldots \ldots \ldots \ldots .2-5$

Table 2.3-1. Assumed Characteristics of Tumulus Disposal . . . . . . . . . . . 2-9

Table 2.3-2. Assumed Characteristics of Shallow-land Burial $\ldots \ldots \ldots \ldots \ldots \ldots \ldots .2-10$

Table 2.3-3. Assumed Characteristics of a Below-ground Vault . . . . . . . . 2-11

Table 3.1-1. Densities of Waste Streams . . . . . . . . . . . . . . . . 3-2

Table 3.1-2. Examples of Waste Volume Percentages for WM Modules . . . . . . . . . . 3-4

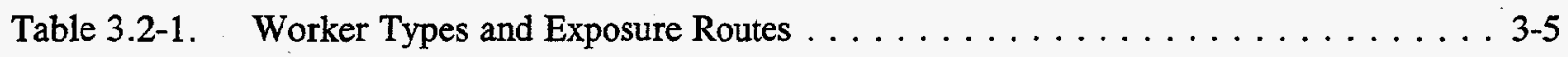

Table A.2-1. Waste Management Activity Types and Worker Types . . . . . . . . A A-3

Table A.2-2. Facility Types and Shielding/Worker Protection Characteristics $\ldots \ldots \ldots \ldots$ A-4

Table A.4-1. WM Module Modeling Parameters . . . . . . . . . . . . . A-22 


\section{ACRONYMS}

\begin{tabular}{|c|c|}
\hline ANL & Argonne National Laboratories \\
\hline DAC & Derived Air Concentration \\
\hline DITTY & Dose In Ten Thousand Years computational model \\
\hline DOE & Department of Energy \\
\hline DUST & Disposal Unit Source Term computational model \\
\hline EDE & Effective Dose Equivalent \\
\hline EG\&G & EG \& G Idaho, Inc. \\
\hline EM & Office of Environmental Restoration and Waste Management \\
\hline EPA & Environmental Protection Agency \\
\hline ER & Environmental Restoration \\
\hline FTE & Full Time Equivalent \\
\hline GENII & Generation II of the Hanford Environmental Radiation Dosimetry Software System \\
\hline HEAST & Health Effects Assessment Summary Tables \\
\hline HEPA & High-Efficiency Particulate Air \\
\hline HLW & High-Level Waste \\
\hline ICRP & International Commission on Radiological Protection \\
\hline $\mathrm{IDLH}$ & Immediately Dangerous to Life and Health \\
\hline INEL & Idaho National Engineering Laboratory \\
\hline INEXPLC & a QuickBASIC computational model \\
\hline IRIS & Integrated Risk Information System \\
\hline ISC2 & Industrial Source Complex Dispersion Models, Version 2 \\
\hline LDR & Land Disposal Restrictions \\
\hline LLMW & Low-Level Mixed Waste \\
\hline LLW & Low-Level Waste \\
\hline MEI & Most Exposed Individual \\
\hline MEL & Most Exposed Lifetime \\
\hline MEPAS & Multimedia Environmental Pollutant Assessment System computational model \\
\hline NAPL & Non-Aqueous Phase Liquid \\
\hline ORNL & Oak Ridge National Laboratory \\
\hline PEIS & Programmatic Environmental Impact Statement \\
\hline PNL & Battelle Pacific Northwest Laboratory \\
\hline RCRA & Resource Conservation and Recovery Act \\
\hline RfD & Reference Dose \\
\hline RTR & Real-Time Radiography \\
\hline SAR & Safety Analysis Report \\
\hline TLV & Threshold Limit Value \\
\hline
\end{tabular}


TRUW Transuranic Waste

TSD Treatment, Storage and Disposal

WAC Waste Acceptance Criteria

WM Waste Management

WIPP Waste Isolation Pilot Plant 


\section{INTRODUCTION}

The United States Department of Energy (DOE) has produced large quantities of radioactive and hazardous waste during years of nuclear weapons production. As a result, a large number of sites across the DOE Complex have become chemically and/or radiologically contaminated. In 1990, the Secretary of Energy charged the DOE Office of Environmental Restoration and Waste Management (EM) with the task of preparing a Programmatic Environmental Impact Statement (PEIS). The PEIS should identify and assess the potential environmental impacts of implementing several integrated Environmental Restoration (ER) and Waste Management (WM) alternatives. The determination and integration of appropriate remediation activities and sound waste management practices is vital for ensuring the diminution of adverse human health impacts during site cleanup and waste management programs. Figure 1.1-1 depicts the components of the PEIS, which include an evaluation of human health risk.

This report documents the PEIS risk assessment methodology used to evaluate human health risks posed by WM activities. The methodology presents a programmatic "cradle to grave" risk assessment for EM program activities. A unit dose approach is used to estimate risks posed by WM activities and is the subject of this document.

The WM unit dose approach is used to estimate risks posed by waste treatment, storage, and disposal (TSD) options throughout the DOE complex. The objectives of the WM health risk evaluation are to assess offsite public, noninvolved worker, and TSD worker risks posed by TSD activities and waste consolidation options. For various consolidation options, risks for both routine and nonroutine (the term "accidents" is used in the PEIS to refer to "nonroutine" events) conditions are evaluated for each waste type found at DOE facilities. For TSD workers, health effects from physical hazards associated with construction and operation of WM facilities are estimated in addition to exposure-related risks.

\subsection{PURPose}

The purpose of this report is to present the specific steps and assumptions used to evaluate potential health risks to offsite, noninvolved worker, and WM worker populations. This document details the steps necessary for a unit dose approach to computing health risks. General guidance for assessing health risks to offsite and noninvolved worker populations and to workers is presented in supplemental documentation (ORNL 1995a; 1995b). 


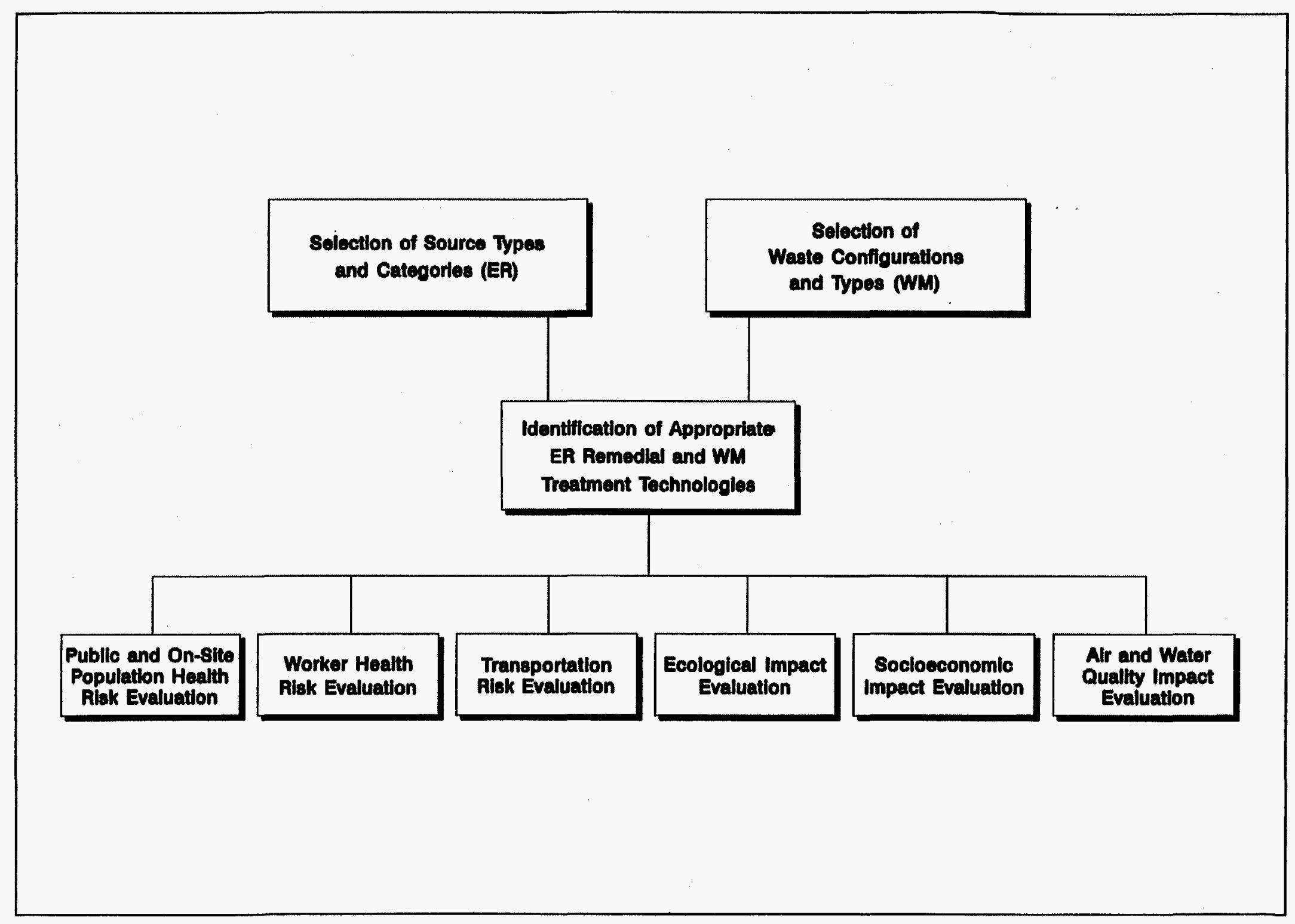

Figure 1.1-1. Components of the PEIS. 


\subsection{ORganization}

Major topics in this report are presented in the following order:

- Chapter 1. Introduction. Chapter 1 includes the objectives and purposes of the PEIS human health risk evaluations for the EM Program.

- Chapter 2. Waste Management Unit Dose Approach: Offsite and Noninvolved Worker Populations. Chapter 2 describes the unit dose approach to assessing baseline risks and health risks associated with WM activities for the public and noninvolved worker populations. Data used in the WM assessment are discussed including environmental setting characterization, potential receptor identification, and TSD facility and process descriptions. This chapter also describes estimation of unit doses and intakes, and total installation risk for the WM public and noninvolved worker populations.

- Chapter 3. Waste Management Unit Dose Approach: TSD Workers. Chapter 3 describes the unit dose approach to assessing risks to TSD workers, including identification of contaminants, modules, worker types and hours, estimation of doses and intakes, and estimation of risk.

Attachment A. WM Technology Assumptions. This attachment provides a description of the WM treatment modules used in the development of unit dose factors. The attachment also serves as a record of assumptions for worker unit dose factor calculations. 


\section{WASTE MANAGEMENT METHODOLOGY: OFFSITE AND NONINVOLVED WORKER POPULATIONS}

The purpose of the WM PEIS is to identify risks associated with TSD options for different waste streams currently being treated and stored throughout the DOE complex (Figure 2-1). This chapter details the unit dose approach used to estimate health risks posed by emissions from TSD facilities to the public and noninvolved worker populations. The waste streams evaluated for the PEIS contain radionuclides and carcinogenic and noncarcinogenic chemical contaminants.

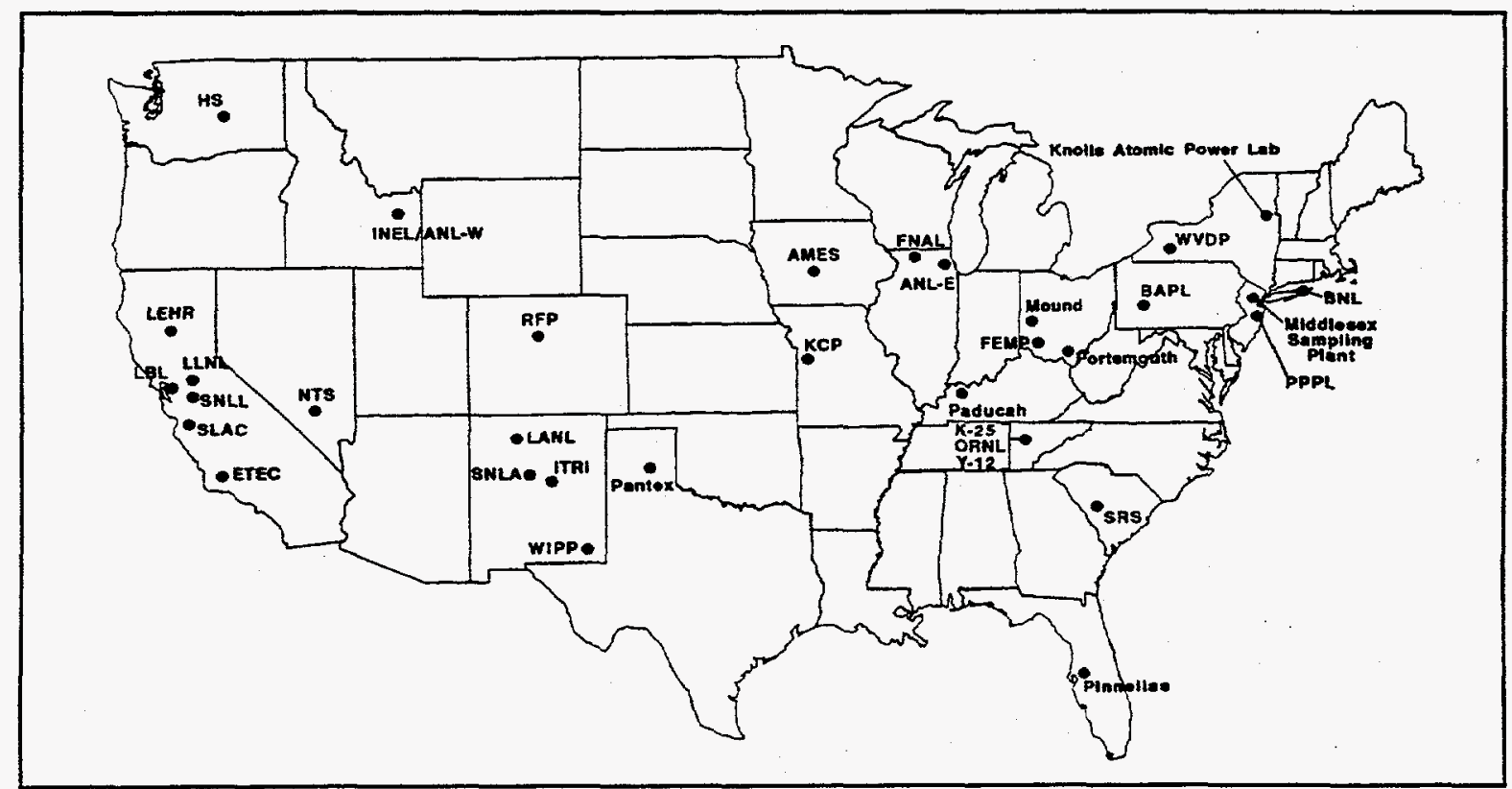

Figure 2-1. DOE Waste Management Installations Throughout the DOE Complex. 
The WM unit dose approach for offsite and noninvolved worker populations involves the following steps:

- Characterize the environmental setting

- Identify potential receptors

- Characterize the TSD facility and treatment processes

- Assume a unit release for each contaminant

- Estimate unit doses and intakes

- Estimate total installation risk for each contaminant.

The WM program focuses on three primary areas of waste handling: treatment, storage, and disposal. Treatment refers to processes such as incineration, solidification, or vitrification, and treatment processes differ depending on the waste type and treatability category (e.g., organic low-level mixed waste) of the waste. Storage may refer to either current or interim storage. Current storage refers to holding the waste at an installation without transferring it to another location for treatment and disposal. However, sometimes waste must be retrieved from current storage before treatment or shipment to another location for storage or disposal (Figure 2-2). Interim storage refers to a temporary stage when waste is awaiting transfer from one location to another to await treatment or disposal. Disposal is a stage of permanent accumulation, either at centrally located facilities such as the Waste Isolation Pilot Plant (WIPP) or onsite at DOE installations.

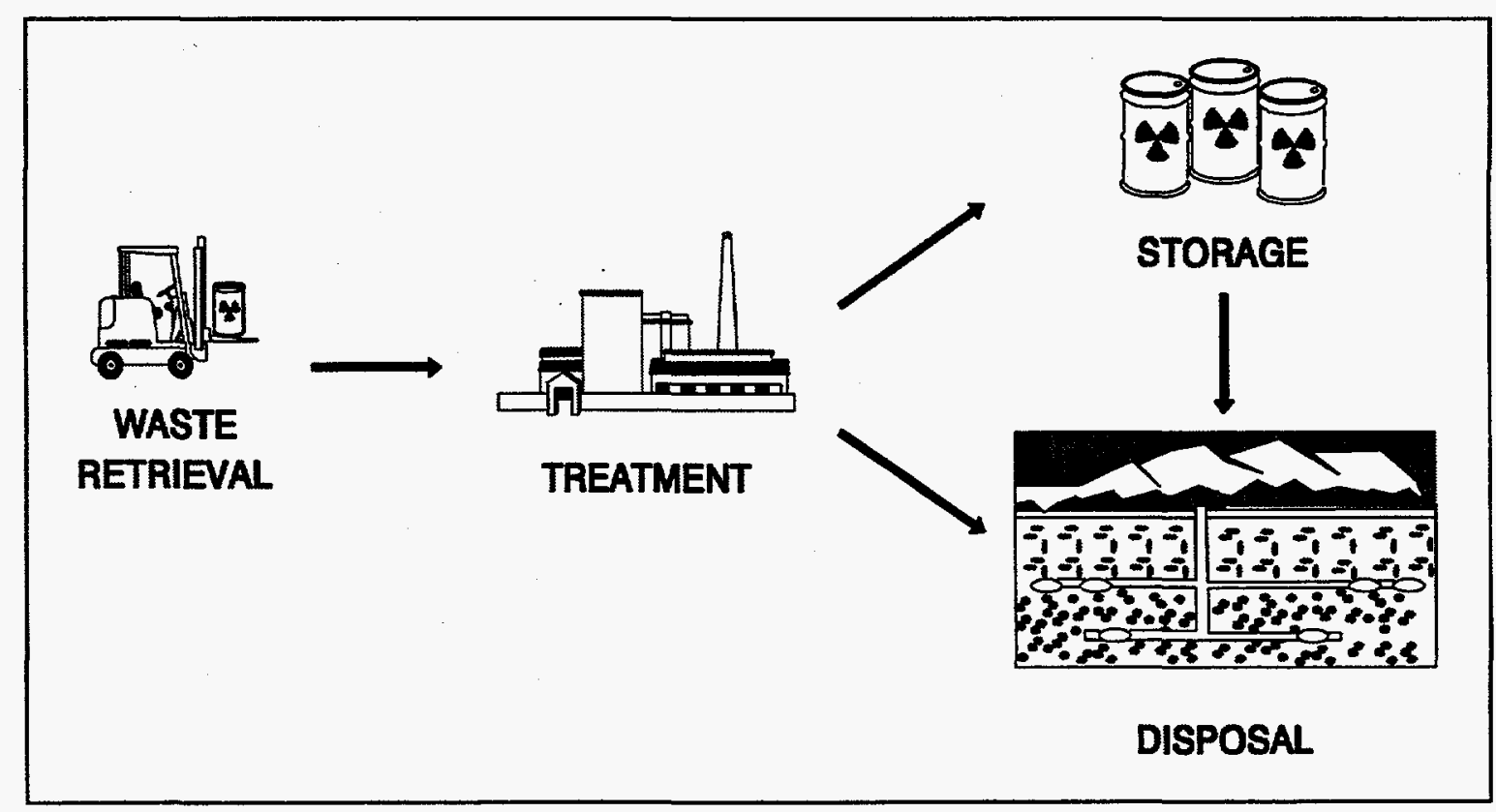

Figure 2-2. Treatment, Storage, and Disposal (TSD) Process. 
Risks are evaluated at TSD facilities for routine operations and nonroutine conditions including a range of nonroutine events while waste is in the treatment and/or storage phase. However, nonroutine events are not evaluated during the disposal phase.

To begin estimating unit doses for offsite and noninvolved worker populations, a unit amount of each contaminant ( $1 \mathrm{Ci}$ for radionuclides and $1 \mathrm{~g}$ for chemicals) is assumed to be released to the air during treatment and/or storage at a TSD facility. For disposal, a unit amount of each contaminant is assumed to be placed in a disposal facility, and the groundwater pathway is evaluated. Estimating unit doses (for radionuclides) and unit intakes (for chemicals) from exposure to contaminants is performed with the aid of computer models or programs that estimate potential exposures of receptors by simulating environmental fate and transport of contaminants from a source to a receptor. Actual risk calculations for various waste consolidation alternatives are then performed by scaling unit doses according to specific source term amounts and then adjusting by scenario-specific parameters (for example, effective stack height, release fractions, and release periods). A summary of the conceptual approach to estimating unit doses is shown in Table 2-1. 
Table 2-1. Summary of Conceptual Approach to Estimating Doses

\begin{tabular}{|c|c|c|c|c|}
\hline Phase & $\begin{array}{l}\text { Transport } \\
\text { Pathway }\end{array}$ & Exposure Route & Receptor & Model \\
\hline $\begin{array}{l}\text { TREATMENT and } \\
\text { STORAGE } \\
\text { - Routine } \\
\text { Emissions } \\
\text { - Nonroutine } \\
\text { Emissions }\end{array}$ & Atmospheric & $\begin{array}{l}\text { - Inhalation } \\
\text { - Ingestion of crops } \\
\text { and livestock } \\
\text { - Direct radiation }\end{array}$ & $\begin{array}{l}\text { - Public within } 50-\mathrm{mi} \\
\text { radius } \\
\text { - Noninvolved workers }{ }^{\mathrm{b}} \\
\text { - Onsite MEI }{ }^{\mathrm{c}} \\
\text { - Offsite MEI }\end{array}$ & $\begin{array}{l}\text { GENII }^{d} \\
\text { ISC2 }^{e}\end{array}$ \\
\hline $\begin{array}{l}\text { DISPOSAL } \\
\text { - Disposal Facility } \\
\text { Breach }\end{array}$ & Groundwater & $\begin{array}{l}\text { - Ingestion of } \\
\text { groundwater } \\
\text { - Ingestion of crops }\end{array}$ & - $\mathrm{MEL}^{\mathrm{f}}$ & $\begin{array}{l}\text { DUST }^{g} \\
\text { DITTY }^{\mathrm{h}} \\
\text { MEPAS }^{\mathrm{I}}\end{array}$ \\
\hline $\begin{array}{l}\text { Post-drilling } \\
\text { Scenario }\end{array}$ & $\begin{array}{l}\text { Atmospheric } \\
\text { (Resuspended } \\
\text { contaminated } \\
\text { soil) }\end{array}$ & $\begin{array}{l}\text { - Direct radiation } \\
\text { - Ingestion } \\
\text { - Inhalation }\end{array}$ & $\begin{array}{l}\text { - Intruder - } 100 \text { years } \\
\text { - Intruder - } 300 \text { years }\end{array}$ & $\begin{array}{l}\text { GENII } \\
\text { PRESTO }\end{array}$ \\
\hline
\end{tabular}

a No ingestion for noninvolved workers populations and no ingestion of chemicals.

b Evenly distributed within installation boundary.

c Most exposed individual.

d Generation II - Estimates doses from atmospheric transport of radionuclides.

e Industrial Source Complex - Estimates air concentrations from atmospheric transport of chemicals.

f Most exposed lifetime hypothetical farm family of four.

g Disposal Unit Source Term - Estimates exposures resulting from the transport of contaminants via groundwater and surface water. Used for the groundwater pathway in tandem with MEPAS and DITTY which are used for surface water.

h Dose Integrated over Ten Thousand Years - Calculates doses for 14370 yr lifetimes. Used in tandem with DUST and MEPAS.

1 Multimedia Environmental Pollutant Assessment System - Can evaluate the transport of contaminants in groundwater, surface water and air. Used to evaluate the transport of contaminants in groundwater. Used in tandem with DUST and DITTY.

j PRESTO - Can evaluate the transport of contaminants in groundwater, surface water, and air. Used to calculate the risk of cancer incidence to an intruder into a disposal facility for carcinogenic chemicals and the hazard index for noncarcinogenic chemicals from the atmospheric (resuspended contaminated soil) pathway.

\subsection{Characterization OF THE ENVIRONMENTAL SeTting}

The fate and transport models used to estimate doses and intakes require specific input relative to each transport medium. Some of the input parameters associated with these transport media are shown in table 2.1-1. 
Table 2.1-1. Transport Medium and Environmental Setting Characteristics

\begin{tabular}{|c|c|}
\hline Transport Medium & Modeling Parameters \\
\hline Air & $\begin{array}{l}\text { - Agricultural Data } \\
\text { - Crop } \\
\text { - Livestock } \\
\text { - Population } \\
\text { - 80-km (50-mi) radius } \\
\text { - Onsite personnel } \\
\text { - Release Parameters (Treatment Facility) } \\
\text { - Stack dimensions } \\
\text { - Flow rate } \\
\text { - Temperature } \\
\text { - Wind } \\
\text { - Joint frequency distribution } \\
\end{array}$ \\
\hline Soil & $\begin{array}{l}\text { - Composition }(\%) \\
\text { - Clay } \\
\text { - Organic matter } \\
\text { - Sand } \\
\text { - Silt } \\
\text { - Porosity } \\
\text { - Effective } \\
\text { - Total } \\
\text { - Number of layers in the vadose zone } \\
\text { - Absorption coefficients for each layer per contaminant } \\
\text { - Bulk density } \\
\text { - Dispersivity } \\
\text { - Saturated hydraulic conductivity } \\
\text { - Horizontal velocity in aquifer } \\
\text { - pH }\end{array}$ \\
\hline Groundwater & $\begin{array}{l}\text { - Direction } \\
\text { - Geometry } \\
\text { - Infiltration rate from surface } \\
\text { - pH } \\
\text { - Velocity }\end{array}$ \\
\hline
\end{tabular}




\subsection{IDENTIFICATION OF POTENTIAL RECEPTORS}

Receptors are people who may be exposed to contaminants that are released from a TSD facility. For the WM PEIS three types of releases are considered: (1) contaminants released to the atmosphere, (2) contaminants released into the groundwater, and (3) contaminants in disposed wastes that are packaged and grouted and released inadvertently by an intruder drilling into the waste form.

Receptors of atmospheric releases, via the air pathway, are defined as (1) the public within an $80-\mathrm{km}$ (50mi) radius of the installation and (2) onsite employees who are not directly involved with TSD and waste handling activities (noninvolved workers). Risks are also calculated for noninvolved worker and offsite most exposed individuals (MEIs). The MEI is the individual (excluding TSD workers) calculated to receive the highest individual dose or intake within the given population.

The receptor of contamination released to groundwater, via the groundwater pathway, is a hypothetical farm family, consisting of two adults and two children, in whose lifetime the highest exposure occurs, and which is designated the most exposed lifetime (MEL) for the purposes of the WM PEIS. The MEL is analyzed because the maximum exposure to contaminants released to groundwater can occur several years or generations following the initial release. The MEL farm family, located $300 \mathrm{~m}$ (328 yd) from the center, and downgradient of the disposal facility can be exposed to contaminants by direct ingestion of groundwater or by ingestion of crops or animals that have been contaminated by groundwater. The $300 \mathrm{~m}$ (328 yd) distance from the center of the disposal facility was chosen for evaluation to ensure that the farm family's well would be beyond the disposal facility boundary.

To identify the MEL for the groundwater pathway, a unit dose is first calculated for each particular contaminant in the inventory. The risks for each contaminant are then summed for each lifetime and the lifetime with the highest risk is the MEL. A lifetime is considered to be a period of $70 \mathrm{yrs,}$ and approximately 143 of the 70-yr lifetimes are evaluated for a total of 10,000 years. The 10,000 year evaluation period was chosen to be consistent with current performance assessments for disposal facilities.

Receptors of contaminated drilling wastes are defined as two hypothetical intruders - one at 100 years after the closure of the disposal facility and the other at 300 years. This post-drilling scenario involves chronic exposure of an individual to contaminated material brought to the surface by drilling a well directly through a waste disposal facility and releasing contaminated soil to be resuspended into the atmosphere. The intruder is then exposed to the contaminant by direct radiation, inhalation, or ingestion. Because the PEIS addresses disposed wastes that are packaged and grouted, it is unlikely that exposures will result from surface excavation and agriculture without inadvertantly drilling into the disposal facility.

Sensitive subpopulations (i.e., children, the elderly, pregnant or nursing women, or people who consume a large quantity of locally grown produce or fish from local water sources) were not specifically analyzed for exposure to contaminants for the WM PEIS. However, these groups were considered in the 
development of the toxicity and exposure values that were used in the analysis; hence, they are indirectly included and risks are assessed conservatively.

For radiological exposures to the elderly, risks are overestimated because of the 50-yr uptake and commitment period. Variations within the public population as a whole exist but not sufficiently to warrant the use of different risk factors (ICRP, 1990). For chemical exposures, risks to sensitive subpopulations are also conservative since an "uncertainty factor" extrapolated from animal data is included and accounts for the effects of the chemical on various human subpopulations.

Sensitive subpopulations consisting of groups that consume relatively large quantities of locally grown produce or fish from local water sources were not differentiated from other members of the offsite population because, (1) surface water contamination was found to be minimal, and (2) it was assumed that all food remained in the area and all population members have the same dietary habits and consumption rates. No variation in risks for minority or low-income populations were assessed because it was assumed that neither dietary habits nor other factors would cause their exposure to be substantially different.

Public population data are obtained from the 1990 census. Noninvolved worker population figures are based on site-specific information. Noninvolved worker population distributions, which are determined from installation maps, are generally assumed to be evenly distributed within known work locations and installation boundaries.

\subsection{DESCRIPTION OF THE TSD FACILITY AND PROCESSES}

The unit dose approach requires that information about the TSD facilities and related processes and waste be described in accurate, mathematical terms. Comprehensive data collection is fundamental to running the computer models and performing the necessary calculations to estimate unit dose. The following are representative types and descriptions of the information necessary to characterize a typical facility:

- Disposal Facility Dimensions: The length, width, and depth of the facility, which will affect both the amount of time required for contaminants to migrate to the facility boundary and the surface area over which a flux into the surrounding soil may occur.

- Treatment and Storage Processes: The types of treatment and storage processes that occur in the facility.

- Waste Treatment, Storage, and Disposal Capacities: The amount of waste that can be treated, stored, or disposed in a particular facility, which will determine the size of the facility or the number of facilities required to handle all of the required waste. 
- Stored Waste Inventory: The amount of waste currently being stored, which will affect the total volume of waste to be treated, stored, and/or disposed and the size or number of facilities required.

- Engineered Safety Controls: Devices, tools, or structures that are designed and used to increase human safety by decreasing exposure to hazardous materials. This definition covers a variety of items such as high-efficiency particulate air (HEPA) filters. Incorporating these controls into modeling assumptions increases the accuracy of the assumptions.

The following types of information are necessary to characterize the TSD process and to further quantify pertinent data:

- Treatability Categories: Groupings or classifications of waste to help determine which TSD process is appropriate. Examples include aqueous liquids, organic liquids, sludge, soil, and debris.

- Storage and Disposal Criteria: Regulations such as land disposal restrictions (LDRs) and waste acceptance criteria (WAC), which are incorporated into modeling assumptions to prevent overly conservative estimates of risk.

Information about disposal methods and installations is also considered. For disposal, three engineered disposal options are considered: (1) the tumulus option, assumed to be used at installations in the eastern United States; (2) the shallow-land burial option, assumed to be used at installations in the western United States (Rocky Flats Environmental Technology Site where the tumulus option is used is an exception); and (3) belowground vaults, which are used at Savannah River Site. The three options are explained below:

- Tumulus Disposal Option. Tumulus disposal (Figure 2.3-1 and Table 2.3-1) consists of an aboveground, vault-type disposal facility made entirely of reinforced concrete. The waste is placed in a metal and concrete cask and then placed inside the vault. Once the vault is filled, it is closed and then covered with a clay soil cap to reduce infiltration.

- Shallow-land Burial Disposal Option. Shallow land burial (Figure 2.3-2 and Table 2.3-2) consists of placing the waste into a long, narrow trench. The waste is stacked on the earthen floor, the voids between the waste containers are filled with earthen material, and the top of the disposal unit is covered with dirt.

- Belowground Vault Disposal Option. Belowground vault (Figure 2.3-3 and Table 2.3-3) disposal consists of placing waste in concrete structures below natural grade. Grout may be pumped into the vault, which is then backfilled with sand and sealed with a concrete roof. The sealed vault is then covered by a multi-layer earthen mound. 


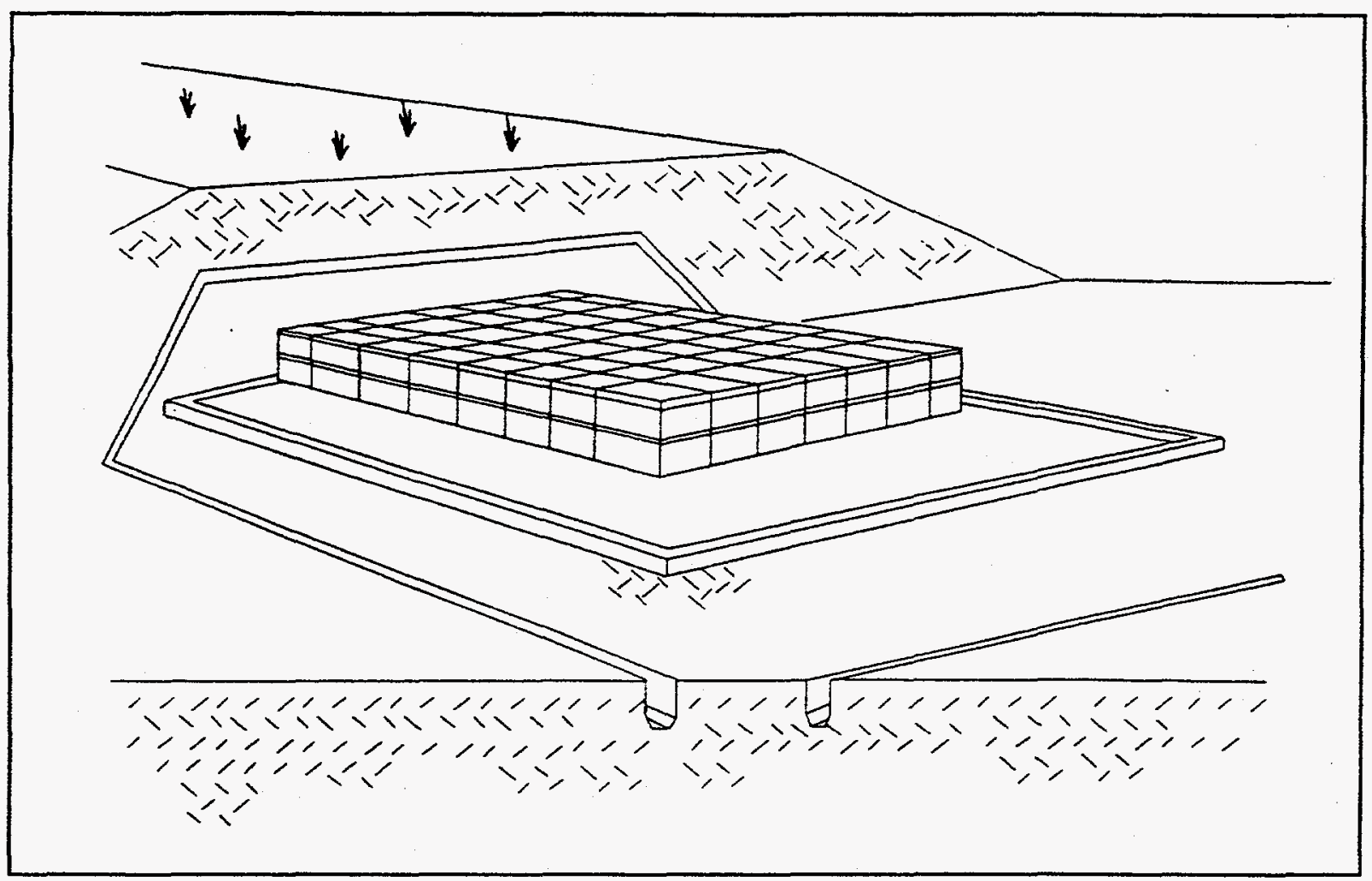

Figure 2.3-1. Illustration of a Tumulus (Aboveground) Disposal Site.

Table 2.3-1. Assumed Characteristics of Tumulus Disposal

\begin{tabular}{||l|l|}
\hline Size & $91 \mathrm{~m} \times 25 \mathrm{~m}(297 \times 81 \mathrm{ft})$ \\
\hline Shape & Rectangular \\
\hline Depth in Soil & 0 feet \\
\hline Capacity & $1.0 \mathrm{E} 4 \mathrm{~m}^{3}\left(383,300 \mathrm{ft}^{3}\right)$ \\
\hline Concrete Thickness & $25 \mathrm{~cm}(10 \mathrm{in})$ \\
\hline Breakdown Time & 300 years \\
\hline
\end{tabular}




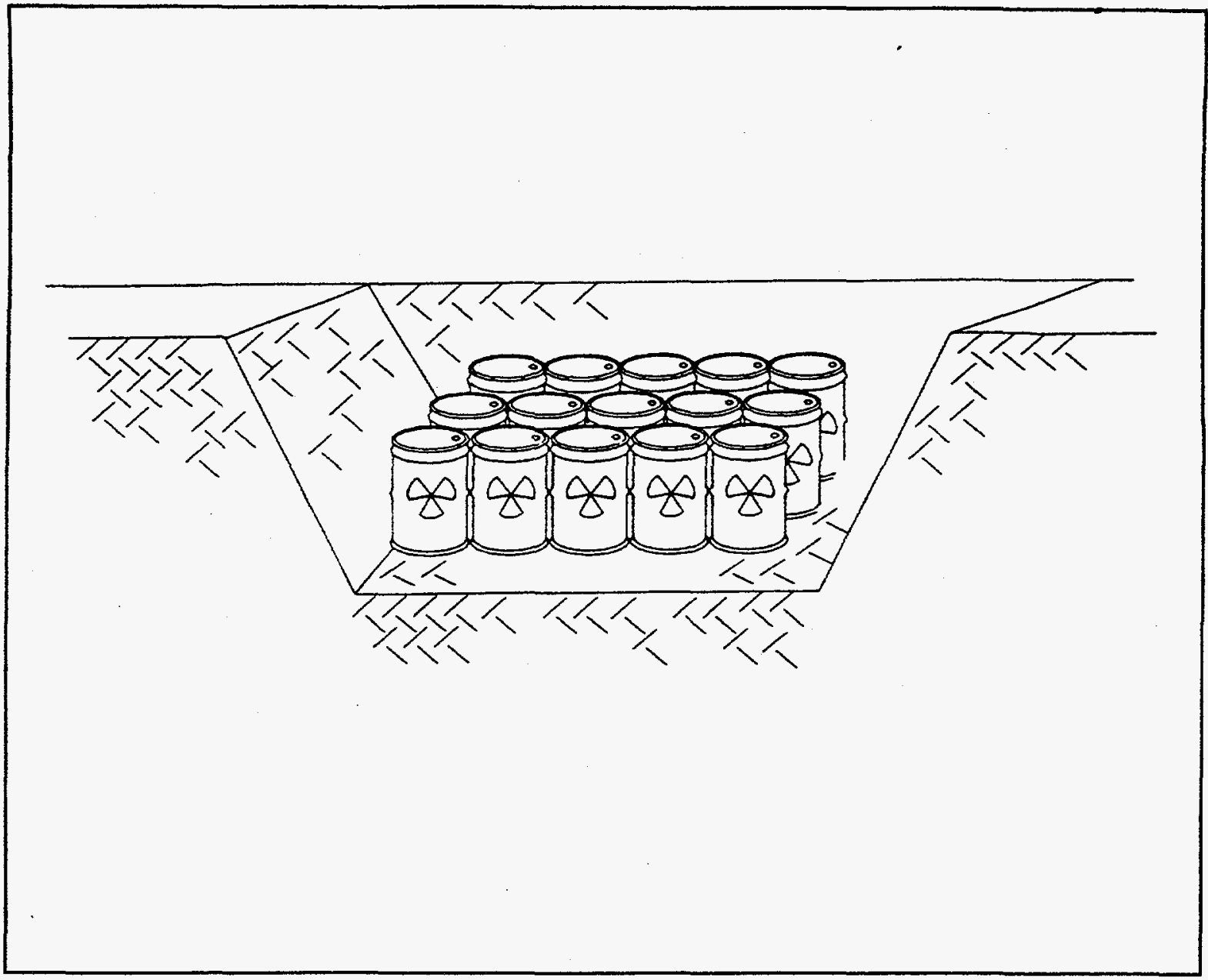

Figure 2.3-2. Illustration of a Shallow Land Burial Site.

Table 2.3-2. Assumed Characteristics of Shallow Land Burial

\begin{tabular}{|l|l|}
\hline Size & $82 \mathrm{~m} \times 16 \mathrm{~m}(270 \times 54 \mathrm{ft})$ \\
\hline Shape & Rectangular \\
\hline Depth in Soil & $9 \mathrm{~m}(29 \mathrm{ft})$ \\
\hline Capacity & $8.0 \mathrm{E} 3+03 \mathrm{~m}^{3}\left(279,000 \mathrm{ft}^{3}\right)$ \\
\hline Concrete Thickness & none \\
\hline Breakdown Time & immediate \\
\hline
\end{tabular}




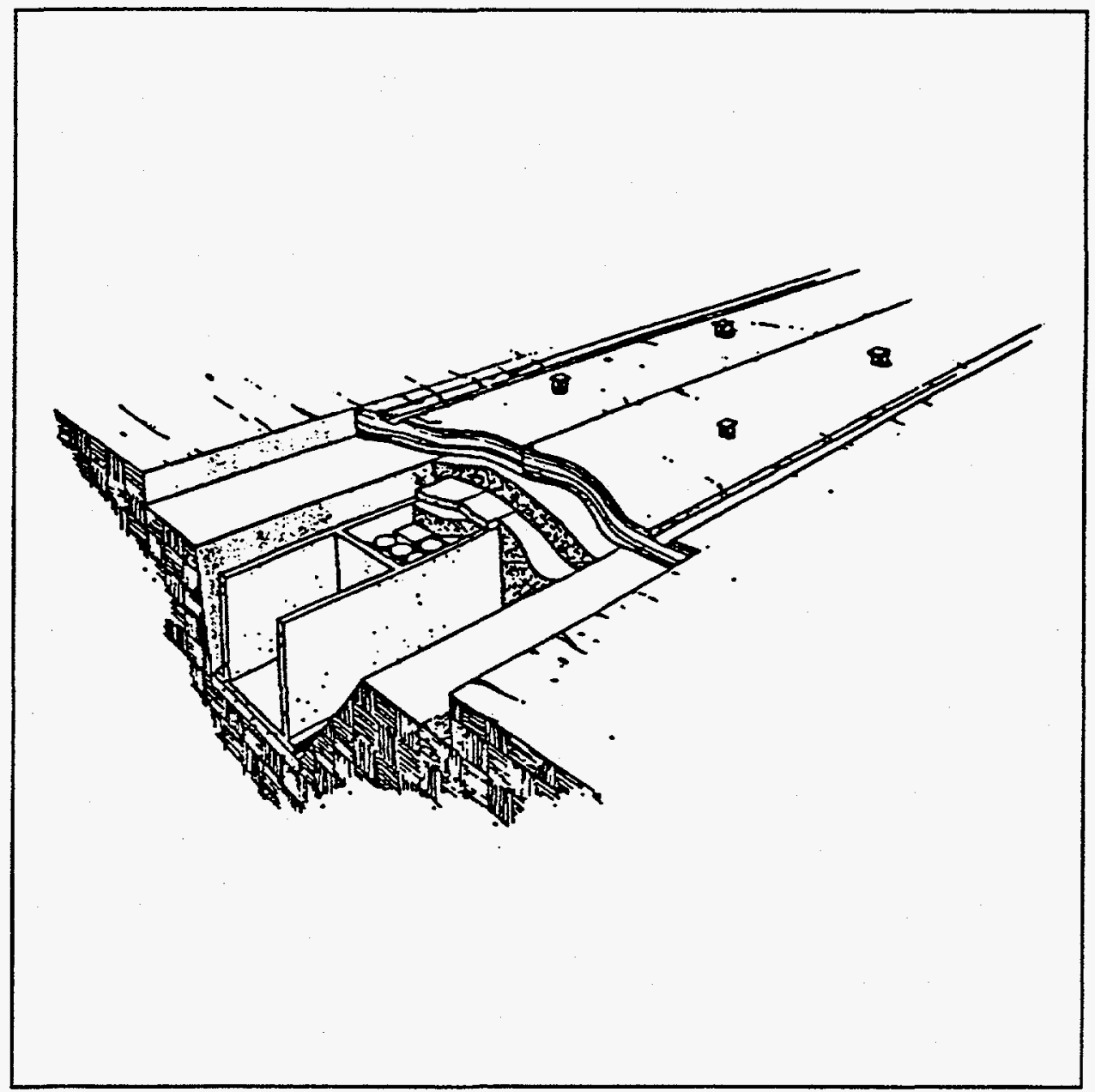

Figure 2.3-3. Illustration of a Belowground Vault.

Table 2.3-3. Assumed Characteristics of a Belowground Vault

\begin{tabular}{||l|l|}
\hline Size & $91 \times 25 \mathrm{~m}(297 \times 81 \mathrm{ft})$ \\
\hline Shape & Rectangular \\
\hline Depth in Soil & $10 \mathrm{~m}(33.5 \mathrm{ft})$ \\
\hline Capacity & $1.0 \mathrm{E} 4 \mathrm{~m}^{3}\left(383,300 \mathrm{ft}^{3}\right)$ \\
\hline Concrete Thickness & $76 \mathrm{~cm}(2.5 \mathrm{ft})$ \\
\hline Breakdown Time & 750 years \\
\hline
\end{tabular}


For the purposes of the PEIS analysis, waste treatment, storage, or disposal may be assumed to occur at an installation that currently has no TSD facility. In these instances, it is assumed that the required facility is constructed on the installation and is subsequently used for TSD activities.

\subsection{ESTIMATING UNIT DOSES AND INTAKES}

Receptors may be exposed to contaminants in different ways because of their varying proximities to the TSD facility emissions and the nature of the release. During treatment and storage, atmospheric pathways only are evaluated for both routine operations and nonroutine events. For disposal, groundwater pathways and the post-drilling scenario are evaluated:

Exposure routes for the offsite population include the following:

- Direct radiation from exposure to contaminated soil

- Inadvertent soil ingestion

- Inhalation

- Ingestion of contaminated food products (plant and animal)

- Plume immersion

Exposure routes for the onsite population include the following:

- Ingestion of contaminated food products (plant and animal)

- Ingestion of contaminated groundwater.

Exposure routes for the noninvolved worker population include the following:

- Direct radiation from exposure to contaminated soil

- Inhalation

- Plume immersion.

Exposure routes for the intruder include the following:

- Direct radiation from exposure to contaminated soil

- Ingestion of contaminated plants and soil (inadvertent)

- Inhalation of contaminated resuspended soil.

For atmospheric transport of radionuclides, doses are estimated by GENII (Generation II of the Hanford Radiation Dosimetry Software System) a model evaluated by the Environmental Protection Agency (EPA). GENII is generally accepted in the field of atmospheric risk assessment, evaluates both acute and chronic 
release scenarios, and uses International Commission on Radiological Protection (ICRP) 26 and 30 dose conversion factors. However, GENII cannot be used to model chemical releases. For atmospheric transport of chemicals, air concentrations are estimated by ISC2 (Industrial Source Complex). ISC2 was designed by EPA and is able to handle both acute and chronic release scenarios.

Exposures resulting from the transport of contaminants via groundwater and are estimated using the DUST, MEPAS, and DITTY models in tandem. DUST is recommended by the Nuclear Regulatory Commission to estimate the leaching of contaminants from an engineered disposal facility. DUST evaluates both radionuclides and chemicals and is also a one-dimensional model that is suitable for the current level of use in the PEIS. MEPAS is used to simulate the transport of contaminants through the groundwater and estimates the environmental concentrations to which receptors may be exposed. MEPAS evaluates both radionuclides and chemicals. DITTY is used to estimate the exposures of receptors resulting from the environmental concentrations predicted by MEPAS. DITTY is an EPA-evaluated model and uses the same exposure modeling methods as GENII.

For radionuclide exposures resulting from contaminated soil the GENII computer model is used to calculate the 50-year cumulative effective dose equivalent (EDE). An enhanced version of the PRESTO computer model is used to estimate exposure to carcinogenic chemicals and noncarcinogenic chemicals.

For each DOE installation, a database is created of unit doses for all known contaminants. The database comprises numerous tables that contain waste type-, installation-, and environmental transport-specific information for waste types, installations, and environmental pathways. For radionuclides, the database contains tables of unit doses by installation, receptor, contaminant, and pathway. For each chemical, the database contains tables of unit intakes by installation, receptor, contaminant, and pathway.

\subsubsection{Radionuclide Releases to Air}

Radionuclides may be released to the atmosphere during routine operations and nonroutine events. The occurrence of operational accidents, natural disasters, or catastrophic events constitute nonroutine event scenarios. Estimation of air concentrations and unit doses/intakes for each of these scenarios is performed differently, as discussed in the following subsections.

\subsubsection{Releases During Routine Operations}

The dose to a receptor from an atmospheric release of radionuclides depends on the spatial and temporal distribution of the radionuclides in the environment. This distribution is a result of the manner of contaminant release and the environment between the release point and the receptor. 
GENII is used to predict the dose to potential receptors by estimating air concentrations in 16 directions at 10 radial distances out to $80 \mathrm{~km}(50 \mathrm{mi})$ from the point of release. To create unit doses for the atmospheric release of radionuclides, GENII is run using an emission rate of $1 \mathrm{Ci} / \mathrm{yr}$ for each radionuclide in the GENII library. To make the doses installation- and receptor-specific, the code is run using installation-specific input files containing information for wind distribution, agricultural yields, MEI locations, and population distributions. A separate unit dose can be generated for both an acute release and a 1-yr release period. The acute unit dose is used to evaluate nonroutine release scenarios, and the 1-yr unit dose is used to project cumulative doses associated with chronic release scenarios associated with routine operations.

This is accomplished using radionuclide-specific cumulative dose conversion equations developed at ORNL that calculate the cumulative EDE based on the number of years of release assuming a 50 -yr commitment period. These equations were developed by plotting the actual cumulative EDE over years of release with the predicted cumulative EDE given a linear relationship of dose to release period and then developing a factor to explain the variance between the two curves. This factor is added to the equation that is used to predict the linear dose and results in an equation that approximates the actual cumulative EDE. The equations were developed by using the unit dose received by the offsite MEI at Hanford. However, the equations are applicable to any receptor at any installation provided the conversion factor is multiplied by the ratio of the Hanford MEI unit dose to the unit dose of the receptor in question. The equation for ${ }^{238} \mathrm{Pu}$ is shown below.

$$
\left[\frac{\text { Unit Dose }}{1.78 \mathrm{E}-03}\right]\left[\left(1.78 \mathrm{E}-03 \times X_{1}\right)-\left[1.01 \mathrm{E}-05 \times\left(X_{1}\right)^{2}\right]+6.44 \mathrm{E}-04\right]
$$

where:

$X_{1}=$ release period $(y r)$

A sample dose calculation for the atmospheric release of ${ }^{238} \mathrm{Pu}$ during interim storage of HLW at Idaho National Engineering Laboratory (INEL) is performed by first multiplying the HLW ${ }^{238} \mathrm{Pu}$ inventory at INEL by the release fraction to determine the stack emission rate for ${ }^{238} \mathrm{Pu}(\mathrm{Ci} / \mathrm{yr})$. Second, the emission rate is multiplied by the 1-yr unit dose to give a 1-yr EDE (rem). Third, the 1-yr EDE is substituted in the ${ }^{238} \mathrm{Pu}$ cumulative dose conversion equation to calculate the cumulative EDE (rem) given the release period (yr). Then the cumulative EDE is multiplied by the appropriate stack adjustment factor to give the adjusted cumulative EDE (rem). Finally, the cumulative EDE is multiplied by a time adjustment factor for release period $>1$ yr.

The appropriate stack adjustment factor is a function of the effective stack height (Figure 2.4-1). Effective stack height is the sum of the actual stack height plus plume rise. Plume rise is a distance above the stack opening at which quantifiable characteristics of the plume are accurately represented. Analysis has shown 
that a log-linear relationship exists between effective stack height and atmospheric concentration. Calculating plume rise is based on the following factors:

- Stack radius

- Flow rate

- Exit temperature

- Wind conditions (speed, direction, stability).

Radiation doses are reported by exposure route (i.e., internal and external). Segregating dose by exposure route is accomplished by calculating the percent contribution of each exposure route to the first year cumulative EDE. Assuming that the percent contribution of each exposure route to the cumulative EDE remains constant over any number of years of release, the percent contribution of each exposure route can be multiplied by the adjusted cumulative EDE to give the dose associated with each route for any specified period of release.

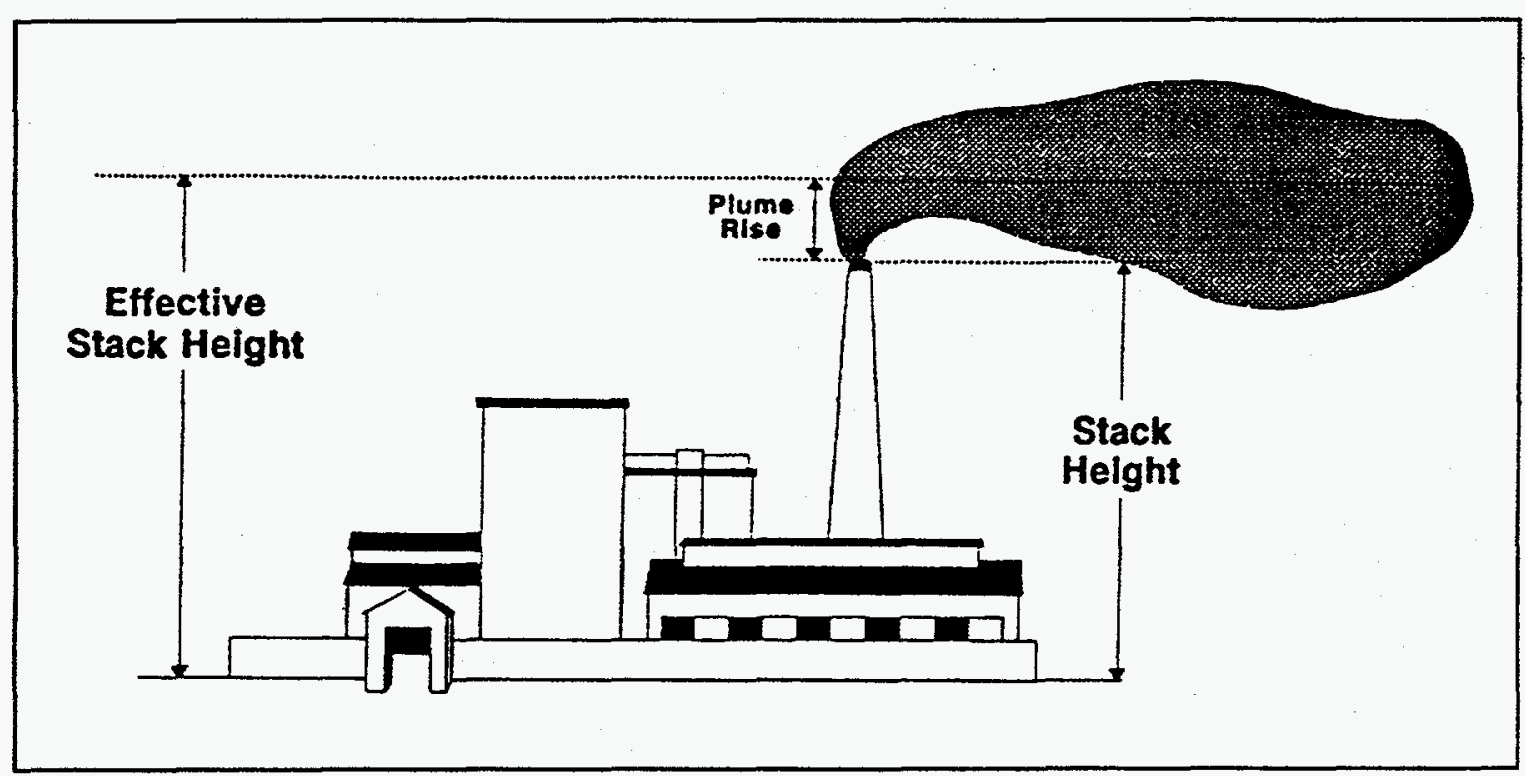

Figure 2.4-1. Effective Stack Height.

\subsubsection{Nonroutine Events}

For nonroutine events involving radionuclides, GENII is used to calculate an acute unit dose to evaluate nonroutine release scenarios. To be most conservative, the population sector that would incur the highest exposure due to atmospheric conditions and population density is modeled for nonroutine scenarios. Nonroutine events are modeled similarly to routine operations. However, the exposure duration for nonroutine events is short-term rather than long-term. 


\subsubsection{Chemical Releases To Air}

Chemicals may be released to the atmosphere during routine operations and nonroutine events. Estimations of air concentrations associated with each situation are performed differently, as discussed in the following subsections.

\subsubsection{Routine Operations}

Receptor exposure to chemicals released to the atmosphere depends on the spatial and temporal distribution of the chemicals in the environment. To create installation-specific unit intakes for the atmospheric release of chemicals, ISC2 is run using an emission rate of $1 \mathrm{~g} / \mathrm{s}$ with installation-specific information for wind distribution. ISC2 predicts atmospheric concentrations based on an emission rate for each block in a grid comprising 16 sectors at 10 radial distances out to $80 \mathrm{~km}(50 \mathrm{mi})$ from the point of release. Thus, running ISC2 with an emission rate of $1 \mathrm{~g} / \mathrm{s}$ yields a distribution of unit atmospheric concentrations. The largest concentration in a block with actual population is used to generate the MEI intake, while the population-weighted average concentration is used to generate the population intake.

Unlike radionuclides, chemical exposures do not involve commitment periods. To generate the unit intakes for chemicals, the unit environmental concentration predicted by ISC2 is converted to a unit intake by multiplying by $20 \mathrm{~m}^{3}\left(26 \mathrm{yd}^{3}\right)$ (i.e., the average daily air intake for humans) and dividing by $70 \mathrm{~kg}(154 \mathrm{lb}$ ) (i.e., the average adult human body weight).

\subsubsection{Nonroutine Events}

For chemicals, the ISC2 model is used to model nonroutine event scenarios. It is assumed that, on average, accidental chemical releases last for one hour. As with radionuclides, the sector that would produce the worst-case risks for each receptor is selected as the one to be modeled. From that worst-case sector, the three most likely wind conditions are chosen and modeled. ISC2 yields the air concentration in an area for the particular sector chosen for the one hour span. The air concentration can then be used to estimate intakes in the same way as for routine conditions, with the exception that for nonroutine events, acute exposure durations are used. Argonne National Laboratory (ANL) has developed acute reference concentration values for noncarcinogenic lethal substances (Hartmann, et al., 1994).

\subsubsection{Contaminant Releases to Groundwater}

DUST and MEPAS are used to assess the groundwater pathway, which is evaluated only for waste disposal options. First, a unit inventory ( $1 \mathrm{Ci}$ or $1 \mathrm{~g}$ ) is assumed to have been placed in the facility. Then, DUST uses a uniform release rate specific for each waste form to simulate the release of radionuclide and 
chemical contaminants from the waste, and calculates the flux rate of each contaminant released from the facility each year for a 1,000-yr time period. These fluxes, calculated by DUST, and the facility-specific hydrogeology parameters, serve as input values for MEPAS.

MEPAS simulates the transport of radionuclide and chemical contaminants over 10,000 yr through any existing vadose zones into the aquifer. MEPAS calculates and reports the average concentration over $70 \mathrm{yr}$ for each contaminant at a specified distance from the waste unit beginning with the first appearance of a non-zero concentration. Since each contaminant can travel at a different rate, the time of first appearance and thus the starting point for each 70 -yr average can differ. This being the case, the 70 -yr average concentrations calculated must be separated by year and re-averaged according to a standard 70 -yr time period, so that 70 -yr concentrations can be compared by contaminant.

DITTY uses the 70-yr average concentrations calculated by MEPAS and information about the exposure of receptors to radionuclide contaminants to predict the dose to receptors.

For hazardous chemicals, the contaminant-specific intake value is calculated from the 70 -yr average concentration by multiplying the average daily water intake for humans (i.e., 2 L [2 qt]) and dividing by the average adult human body weight (i.e., $70 \mathrm{~kg}[154 \mathrm{lb}]$ ).

\subsubsection{Exposure to Soil/Contaminated Drilling Waste}

Exposure is estimated for an individual adult who inadvertantly drills a well directly through the waste disposal facility down to the water table and brings the contaminated material from within the disposal facility to the surface during drilling. The contaminated material is mixed into the top $15 \mathrm{~cm}(6 \mathrm{in})$ of surface soil of a $2500-\mathrm{m}^{3}$ (3720-yd $\mathrm{d}^{3}$ ) plot of land, (i.e., $375 \mathrm{~m}^{3}$ [490 $\left.\mathrm{yd}^{3}\right]$ of farm plot soil). The individual farms this plot and feeds him- or herself with the crops. GENII is used to estimate radionuclide exposure due to inhalation, ingestion and crop uptake of contaminated soil. PRESTO is used to calculate exposure to hazardous chemicals.

\subsection{ESTIMATING TOTAL INSTALLATION RISK}

Once unit doses and intakes have been determined for the contaminants of a particular installation, they are scaled up based on the waste inventory at that installation. To estimate exposures posed by each particular contaminant at the installation, the inventory for each contaminant is first multiplied by the fraction of contaminant released during TSD activities. This product, the source term, is the estimated amount of contaminant released to the environment that could result in exposure. 
Risks are estimated for all of the contaminants in the installation's source term by using the cumulative doses and intakes and the appropriate toxicity values and risk factors from EPA and ICRP (ORNL, 1995a).

For each carcinogenic chemical, the intake is multiplied by a chemical-specific EPA cancer potency factor to yield risk of cancer incidence.

For each noncarcinogen, the intake divided by the chemical-specific EPA RfD results in a hazard quotient for one individual. Hazard quotients are calculated for all of the hazardous components in a mixture and the results are summed to yield the hazard index. A separate RfD is used to generate hazard quotients for chronic and subchronic releases. Chronic releases are those lasting more than $7 \mathrm{yrs}$, while subchronic releases are those lasting between 2 wks and 7 yrs.

For radionuclides, collective/cumulative doses are multiplied by the appropriate risk factor derived from ICRP 60. Depending on the risk factor used, risks can be calculated for cancer fatality, cancer incidence, and adverse genetic effects (ORNL, 1995a).

Once the risks for all of the source term contaminants are calculated, they are summed to yield the total risk for each exposure route. The risks for each route associated with TSD facilities can then be summed to give the installation's total risk.

A sample risk calculation for the atmospheric release of benzene during interim storage of hazardous waste at INEL would be performed by the database by first multiplying the benzene inventory at INEL by the release fraction to determine the stack emission rate for benzene $(\mathrm{g} / \mathrm{s} / \mathrm{yr})$. The benzene emission rate is multiplied by the unit dose for INEL for benzene to give the projected dose based on $1 \mathrm{yr}$ of release. Then the dose for one year of release is multiplied by the actual release period being evaluated and by the appropriate cancer potency factors to yield the risk of cancer incidence.

\subsection{ESTIMATING RISK FOR WM ALTERNATIVES}

Once unit doses for each installation have been generated and stored, human health risks associated with various TSD alternatives can be calculated by manipulating the WM PEIS database and total risk at each installation can be determined.

Based on installation-specific waste inventory tables, locations are determined for consolidating waste in preparation for various TSD alternatives. Combined inventory tables are merged into one database to provide a consolidated inventory for each alternative. The new inventory of the consolidated waste in the WM PEIS database is multiplied by module-specific release fractions associated with the technology to estimate source term at each installation. The source term is multiplied by installation-specific unit doses. These initial dose estimates are then adjusted to account for the actual stack heights and release periods 
associated with an alternative. The adjusted dose is converted to the risk of an alternative at an installation by multipling each dose by the appropriate risk factors.

Finally, risks for carcinogens are calculated and summed across installations to yield an estimate of total risk for each alternative. For noncarcinogens the highest hazard index at any installation is reported as the risk for an alternative.

\subsection{ASSUMPTIONS AND UNCERTAINTIES}

The goal of the PEIS is to evaluate the relative risks posed by the different waste TSD alternatives if implemented nationwide, rather than to provide the detailed analysis required in a site-specific environmental impact statement. The assumptions made in performing this program-level evaluation were intended to yield "conservative" risk estimates (i.e., estimates that tend to overestimate risk).

Given the programmatic nature of the PEIS many of the uncertainties associated with using the unit approach are "systematic," as many assumptions were applied "systematically" throughout the analysis. For example, if a risk is overestimated in the analysis for one installation, it is similarly overestimated in the subsequent analyses for all other installations. When considered individually, the overestimates or underestimates associated with the assumptions described below may seem significant. However, when the assumptions are made for a comparative analysis such as the PEIS, the relative risks across the entire DOE complex are not affected because the same assumptions are consistently used in all cases. The result is that systematic uncertainties may not affect decision making across the entire DOE complex. Other uncertainties specific to a particular installation must be carefully considered to minimize the chance that they will skew the comparison of alternatives. These are documented separately as part of the risk results for each installation. Those uncertainties that are common to all installations are discussed in the PEIS.

In either case, it is important that a qualitative and/or quantitative assessment of uncertainties be incorporated into the presentation of risks generated by the unit approach. A qualitative analysis assesses the general accuracy and acceptability of data, algorithms, and assumptions used in the risk assessment and may also provide an indication of the direction of error associated with the risk estimates (i.e., whether they are overestimates or underestimates). A quantitative analysis provides an estimation of both the direction and magnitude of potential errors associated with the risk estimates.

Finally, although worst-case scenarios provide conservative estimates of risk, their use does not decrease the uncertainty associated with the risk estimates. Moreover, the tendency to overestimate risks when performing an already conservative risk estimate is compounded whenever a worst-case assumption is used. Uncertainty assumptions can be classified into three broad categories: model uncertainty, scenario uncertainty, and parameter uncertainty. These types of uncertainties are discussed in the following sections. 


\subsubsection{Model Uncertainties}

Model uncertainty may result from the general limitations of mathematical simulations. The assumptions for the models used in the PEIS are based on a combination of actual data, best available data, estimation techniques, and professional judgement. As such, risk estimates produced are associated with varying degrees of uncertainty. These uncertainties are discussed below.

The WM PEIS risk analyses use the GENII and ISC2 models to predict receptor exposure to contaminants released to the atmosphere. Both models assume that the contaminant plume is not depleted as it migrates away from the point of release (contaminants in an actual plume are deposited on trees, the ground, and structures such as buildings as the plume migrates; thus, the concentration of contaminants in an actual plume diminishes as the plume travels). This results in an overestimation of atmospheric concentrations and subsequent risks. For acute releases (one-time, high-concentration releases as opposed to constant, low-concentration releases), GENII considers exposures in a single sector because winds can only blow in one direction during an instantaneous release. We have assumed that this direction will be the direction of worst exposure to the receptor(s); this also results in an overestimation of risks. Additional modeling uncertainties involve neglecting complex terrain and building wake effects, which could result in overestimation or underestimation of contaminant air concentrations and risk.

WM uses the DUST model to estimate the "source term" (the amount of contaminant released and available for environmental transport) associated with the disposal of wastes in engineered facilities. Although the DUST model allows the user to define the physical and geometrical characteristics of the facility, it is assumed that the facility operates for a specified time period, then breaks down all at once rather than deteriorating gradually as is most likely.

For WM, the MEPAS model is used to simulate contaminant transport through the groundwater for scenarios involving disposal facility failure. Even when a model such as MEPAS has been validated, uncertainty may exist when it is applied to situations beyond the test system for which it was developed.

Groundwater transport of contaminants is modeled using MEPAS in successive stages from the contaminated zone to the vadose (unsaturated) zone to the saturated zone to a well or to surface water. Transport through partially saturated zones is a one-dimensional vertical dispersion. Transport through the saturated zone is one-dimensional advection with three-dimensional dispersion longitudinally, laterally, and vertically. A uniform, homogeneous soil distribution is assumed in each zone. Not considered are multiple and perched aquifers, nonaqueous phase liquids (NAPLs), and radionuclide progeny (radionuclide decay during transport). Neglecting perched aquifers may cause the transport of contaminants to occur sooner, resulting in an overestimation of risk in the near term and underestimation of risks in the more distant future. Neglecting radionuclide progeny may overestimate or underestimate risk since the daughter nuclides may be more or less detrimental to health than the parent nuclides and their rate of movement through the environment may change. 
Often, a contaminant can exist in a number of different chemical forms in an actual release plume. These forms may include different electrochemical charge states (mercury has several) or different combinations of the same types of atom (the different combinations of nitrogen and oxygen are collectively referred to as $\mathrm{NO}_{x}$ ); this phenomenon is referred to as "speciation." Contaminants can also form tight associations called "complexes" with clay particles, metals, or other substances. Complexing and speciation can affect physicochemical and health-related factors including the toxicity, carcinogenicity, reactivity, and water solubility (hence, transportability) of a contaminant. This analysis does not account for contaminant complexing and speciation; instead, all source terms for the analysis are provided on a contaminant-by-contaminant basis. Thus, contaminant complexing and speciation may contribute to modeling uncertainty.

Uncertainties are also associated with estimating the risks of contaminant mixtures. Some combinations of contaminants may produce "additive" health effects in a receptor. For example, contaminant A may cause a health effect of magnitude $A$ when it acts alone; contaminant B may cause a health effect of magnitude $B$ when it acts alone; and the two in combination may cause a health effect that is the sum of the magnitude of both effects, $A+B$. However, some contaminant combinations may produce health effects substantially greater than the sum $A+B$. This enhanced effect is called "synergism." Likewise, some combinations of contaminants may somewhat suppress or diminish each other's health effects; this is called "antagonism." Because this is a program-level evaluation, and because few data exist on the possible synergistic and antagonistic actions of WM contaminants, the PEIS risk analysis considers only additivity. If synergism or antagonism are occurring, risks could be accordingly under- or overestimated.

\subsubsection{Scenario Uncertainties}

Scenario uncertainty may result from a generalized conceptualization of a contaminant release or an exposure scenario. Scenario assumptions associated with the WM PEIS analyses include the categories listed below:

- Agricultural food products are not imported or exported.

- Population size and distribution remain constant.

- No plume downwash due to buildings or rough terrain occurs.

- Risks are considered only for chemicals that have toxicity parameters listed in the U.S. Environmental Protection Agency's Integrated Risk Information System (IRIS) or Health Effects Assessment Summary Tables (HEAST).

Assumptions regarding the intake of contaminated food products may introduce uncertainty in atmospheric pathway modeling. For example, the unit doses in the database reflect the assumption that agricultural food products are not imported into or exported outside of an $80-\mathrm{km}(50-\mathrm{mi})$ radius surrounding a particular installation. This is a conservative assumption and produces an overestimate of dose and risk. 
If buildings and rough terrain surround the point of contaminant release, it is assumed that they do not cause contaminant plume downwash. This conservative assumption tends to overestimate risk for offsite receptors.

The PEIS includes an evaluation of the uncertainties associated with the databases of risk estimates. This evaluation was made by performing "sensitivity tests" for the parameters used in the models then running the models with a realistic range of values for the parameters found to be most sensitive. Ideally, an uncertainty analysis would be performed on each scenario modeled. However, considering the thousands of scenarios modeled to create the database, this approach is not feasible. As such, uncertainties will be analyzed for several representative scenarios as presented in the PEIS appendices.

\subsubsection{Parameter Uncertainties}

Parameter uncertainty may result from sampling errors, natural variability of the parameter, or the use of generic data (data that are not site-specific). Sampling allows the assessor to make inferences about the nature of the whole (such as a contaminated groundwater plume, an impoundment, or a particular population) from measurements of a subset of the total population (such as groundwater samples, water samples from the impoundment, or a representative group from a population) and will almost certainly contribute to parameter uncertainties. In addition, uncertainty may be introduced if the data do not represent the exposure scenario being analyzed. This situation might arise if the data used were collected for a different kind of study (for which the data requirements might have been different).

Another source of uncertainty is the inherent variability in environmental and exposure-related parameters, and the inability to characterize that variability. As an example, meteorological and hydrological conditions at a given location can vary seasonally. Similarly, soil conditions can vary widely within a given area. Human activity patterns may also vary by sex, age, and geographic location.

When site-specific data are not available, generic or surrogate data are commonly used. Generic data such as standard emission factors for industrial processes or generalized environmental settings are often used in place of site-specific data. Likewise, data pertaining to structurally-related chemicals are often substituted as surrogates when data about the chemical of interest is unavailable. The use of such generic data results in an additional source of uncertainty and is avoided if actual data can be obtained.

Assumptions specific to the PEIS that affect the results include population distributions, toxicity parameters, pathways, contaminant characteristics, and transport parameters. Population rings originate from the point of release for most installations evaluated in the PEIS, although some originate from the center of the installation. Therefore, errors in assumptions about receptor distribution may contribute to uncertainty, but is likely to be minimal and should have little effect on risk estimates. 
Toxicity parameters such as dose conversion factors, cancer potency factors, and reference doses (RfDs) contribute to uncertainty. Toxicity values are generally best estimates, but each factor is associated with varying degrees of uncertainty and must be evaluated individually to determine how the value was derived and the level of confidence associated with it. For example, the cancer potency factors used in this evaluation are $95 \%$ confidence level values.

The risk estimates associated with radionuclide constituent pathways are assumed to have less uncertainty than the risk estimates for chemical pathways because the body of data on the human health effects caused by radionuclides is larger than that for chemicals. Noncarcinogenic constituents with toxicity data based on $\mathrm{LD}_{50}$ (the dose that would be lethal to $50 \%$ of an exposed population) have the greatest uncertainty.

Risk estimate uncertainty can also be attributed to the parameters used to estimate health impacts from environmental concentrations. These data are contaminant-specific and include both the physicochemical properties of the contaminants and data from health effect studies. In general, the physical and chemical properties of the constituents are not difficult to obtain and their values contain only a small amount of uncertainty. Only the additive health effects of contaminant combinations were taken into account in this study, not synergism or antagonism.

For scenarios associated with the atmospheric transport of contaminants, receptor distribution and joint frequency data are the most sensitive parameters, but the uncertainty associated with these parameters may be small. The joint frequency data usually represent measurements of wind direction, speed, and stability averaged over 3- to 5-yr periods. Because these values are averages obtained over relatively long time periods, their uncertainty is generally low.

For scenarios involving groundwater pathways, contaminant distribution coefficients $\left(K_{d} s\right)$ will likely be the most sensitive parameters and may also contain a great deal of uncertainty. Contaminant-specific $K_{d} s$ for organic chemicals and radionuclides are selected from a three-by-three matrix of possible values correlated to the $\mathrm{pH}$ and the percent iron, organic matter, and clay in the soil. For inorganic chemicals, the $\mathrm{K}_{\mathrm{d}} \mathrm{s}$ are a function of the octanol-water partitioning coefficient $\left(\mathrm{K}_{\mathrm{ocw}}\right)$ of the chemical, and the percent sand, silt, and clay in the soil. The $K_{d}$ values in the three-by-three matrix and the $\mathrm{K}_{\mathrm{ocw}}$ can vary by as much as a factor of 1000 for a particular contaminant. 


\section{WASTE MANAGEMENT METHODOLOGY: WM WORKERS}

The management of waste already being treated and stored at DOE installations and waste that will be generated by ER activities requires the effort of thousands of workers. Workers are defined to be those directly participating in the construction of TSD facilities and the TSD of waste at DOE facilities. WM operations pose potential risks to workers through exposure to contaminants during routine TSD operations and nonroutine events. Workers may also face construction and operational hazards associated with TSD activities. The objective of the worker risk portion of the WM PEIS is to assess WM worker risks posed by TSD processes at various installations. TSD facilities do not exist at some installations. In these cases, the TSD facilities are assumed to be constructed, incurring risks to workers from construction-related hazards. Risks are presented in terms of cancer incidence, cancer fatalities, genetic effects, and injuries and fatalities for construction- and operation-related hazards.

Unit doses or intakes are derived to determine risks posed by TSD activities at an installation. Unit doses are estimated per contaminant and exposure route (e.g., inhalation, direct radiation) for each WM module. A module is a self-contained waste handling or treatment process (e.g., receiving and inspection, incineration, packaging) where workers treat or handle waste as it is processed through a facility. The module houses a process and serves as a "box" within which the workers labor. Fugitive emissions from treatment processes may be released into this "box." A facility can contain several treatment modules, each containing subactivities with different unit doses or intakes. The unit dose or intake is derived by estimating for each module the worker exposure to a unit amount of contaminant (1 Ci) for the direct radiation exposure route or to a unit contaminant air concentration from fugitive emissions (chemical or radionuclide) or resuspended particulates (radionuclides) for the inhalation exposure route.

Worker risks are estimated for various combinations of WM modules chosen for the TSD of a given waste type. Evaluation of worker risks using the WM unit dose approach involves the following steps:

- Identifying process/handling modules and subactivities within modules

- Estimating unit doses and intakes for each subactivity, module, exposure route, and contaminant

- Estimating personnel staffing (full-time equivalents [FTEs]) required for each module

- Determining person-hrs, module capacities, and contaminant inventories

- Computing exposure and safety risks based upon this information for each TSD facility.

Unit doses and intakes are estimated for two exposure routes: inhalation and direct radiation. Ingestion and dermal contact exposure routes are not evaluated, since inhalation and direct radiation exposure routes 
tend to drive the risk. Exposures of workers during nonroutine events are evaluated, in addition to the evaluation of routine exposures and hazards faced by workers during TSD activities.

\subsection{Module IDENTIFICATION}

WM modules are essentially self-contained waste management processes. A facility may contain one or several modules, each of which may contain subactivities for which unit doses must be calculated. The facilities are divided into cells, each containing a different treatment module. Airlocks separate the process modules in alpha- and remote-waste treatment facilities to guard against inhalation exposure.

Treatments differ among the waste streams (e.g., low-level waste [LLW], low-level mixed waste [LLMW] transuranic waste [TRUW]); therefore, each waste stream may require a different set of modules. The densities of the waste streams must be taken into account when estimating exposure via direct radiation since denser source materials provide more attenuation of radiation emitted from the source (i.e., selfshielding). Each waste stream processed in a given module may have a different density that results in a different dose rate to workers who handle or process the waste. For the PEIS, an average density was calculated for each major waste stream based on the weighted densities of the types of materials (e.g., organic liquids, soil, metals, debris) comprising each waste stream. These computed densities are shown in table 3.1-1.

Table 3.1-1. Densities of Waste Streams

\begin{tabular}{|cc|}
\hline Waste Stream & Weighted Average Density $\left(\mathbf{g} / \mathbf{c m}^{\mathbf{3}}\right)$ \\
\hline LLW $^{\mathrm{a}}$ & 1.08 \\
LLMW $^{\mathrm{b}}$ & 1.23 \\
TRUW $^{\mathrm{c}}$ & 2.26 \\
\hline
\end{tabular}

a Weighted average density based on information provided by ANL regarding representative LLW densities and composition (Goyette, M., ANL, fax to J. Legg, ORNL, October, 1993).

b Weighted average density based on LLMW density and composition information provided by ANL (Goyette, M., ANL, fax to J. Legg, ORNL, October, 1993), EG\&G Idaho, Inc. (Shropshire, 1993), and the US DOE Interim Mixed Waste Inventory Report (DOE, 1993).

c Weighted average density based on information provided by ANL (Goyette, M., ANL, fax to J. Legg, ORNL, October, 1993) and in DOE (1991).

Module selection is a waste stream- and facility-specific process determined by process engineers or other qualified personnel. Some of the most common WM modules are categorized by activity (i.e., preparation, 
treatment, storage, disposal), as shown in figure 3.1-1. A more detailed discussion of WM modules is provided in attachment $A$.

When it is assumed that a new or additional facility is constructed waste consolidation alternatives determine the size (capacity) of the TSD facility required to process volumes of waste. If the waste treatment and waste storage for high-level waste (HLW) were consolidated at one installation, the TSD facility at that installation would have to be large enough to handle the extra volume of HLW. In addition, the required treatment module capacity (volume of the process vessel) must be determined.

Module capacity is a major factor in determining the risks to workers. A module with larger capacity can process more waste at one time, which allows the workers to be exposed to more contaminants. Thus, the module capacity determines the amount of contaminants to which the workers are exposed during a particular activity. To estimate the module capacity, a throughput rate must first be determined. The throughput rate is determined by the size of the facility and the amount of time required for waste processing for a particular installation and WM alternative. For the PEIS, ANL has provided these data as input for the worker health risk evaluation.

Preparation

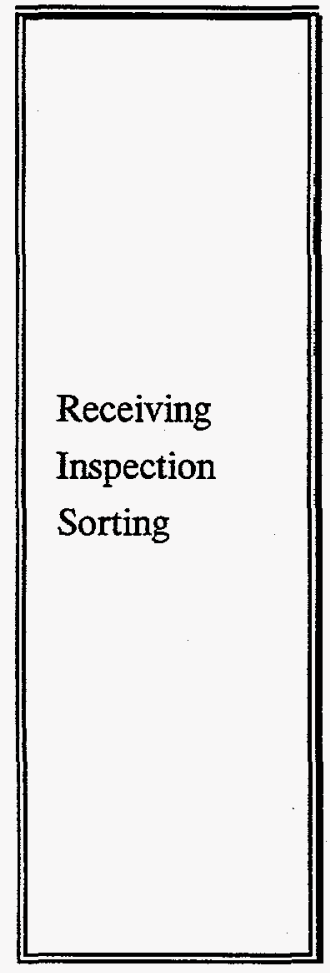

Treatment

\begin{tabular}{|l||}
\hline Incineration \\
Metal melting \\
Sizing/shredding \\
Decontamination \\
General aqueous \\
treatment \\
Solidification \\
Vitrification \\
Evaporation/concentration \\
Wet-air oxidation \\
Mercury separation \\
Lead recovery \\
Thermal desorption \\
Packaging \\
Polymer stabilization \\
Ion exchange \\
\hline
\end{tabular}

Storage

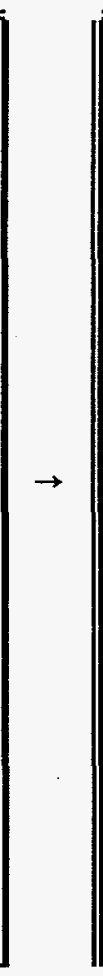

Disposal

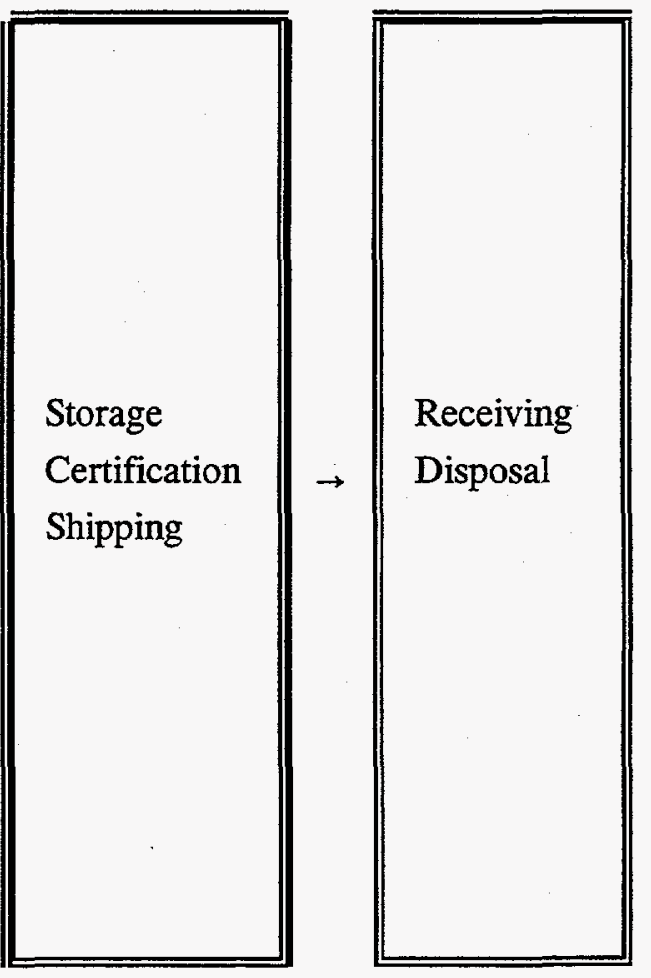

Figure 3.1-1. Example WM Activities. 
If the module does not vary in size, the module capacity is set to a predetermined amount. For example, the inspection activity always involves one drum or waste container which yields a fixed volume of waste. If the module size varies with the throughput rate, the module capacity is estimated using regression equations based on the relationship between the facility throughput rate and treatment vessel size. The throughputs and equipment sizes are provided by EG\&G Idaho, Inc. (EG\&G) in the PEIS WM facility analysis (EG\&G, 1992; Morrison Knudsen, 1993, 1994).

Once the module capacity is determined, it is multiplied by a percentage which yields the actual volume of waste in the module. For example, a shredder may be only $40 \%$ full of waste during the shredding process. Table 3.1-2 shows examples of waste volume percentages for WM modules.

\section{Table 3.1-2. Examples of Waste Volume Percentages for WM Modules}

\begin{tabular}{|lc||}
\hline \multicolumn{1}{|c|}{ Module } & Waste Percentage $^{\mathbf{a}}$ \\
\hline Shredder & $40 \%$ \\
Incinerator & $50 \%$ \\
Solidification & $20 \%$ \\
Metal melting & $80 \%$ \\
Vitrification & $50 \%$ \\
Evaporation & $90 \%$ \\
Mercury separation & $90 \%$ \\
Thermal desorption & $30 \%$ \\
Polymer stabilization & $20 \%$ \\
\hline
\end{tabular}

a Morrison Knudsen, 1993, 1994.

During waste treatment, the total waste volume may change due to different treatment processes. For example, waste processed in a compactor may be reduced to $20 \%$ of its original volume; therefore, the package and shipping waste volume will be $80 \%$ less than the original total volume. Although the volume of the waste can be reduced through treatment processes, the contaminant inventory may remain the same (unless the module is specifically designed to remove contaminants). When waste moves from one module to another module in a treatment train, the new (reduced, increased, or identical) waste volume is used to calculate the module capacity and contaminant concentration in the subsequent module. For the PEIS analysis, waste volumes and contaminant inventories are provided by ANL for the worker risk evaluation for each module in the treatment train.

To calculate the total inventory of contaminants in a module, the inventory of each contaminant in the waste is divided by the total waste volume processed in the module to produce a concentration. The 
contaminant concentration is then multiplied by the computed module capacity to yield the total inventory of the contaminant within the module. Dose rates and/or intakes can be calculated from the contaminant inventories for the module using dose assessment computer codes and models.

\subsection{IDENTIFICATION OF WORKER TYPES AND HOURS}

The types of workers involved in waste management vary depending on the activities necessary to handle, treat, store, and dispose of waste. Worker types and their associated exposure routes and hazards are presented in table 3.2-1. The number of hours spent by a worker in a handling and processing module is required for determining the risk associated with the implementation of a module at a given facility. The number of worker hours spent processing waste through a module depends upon the waste volume and facility throughput.

Table 3.2-1. Worker Types and Exposure Routes

\begin{tabular}{||c|c|c|c|c|c||}
\hline \multirow{2}{*}{$\begin{array}{c}\text { WM Activity } \\
\text { and } \\
\text { Worker Types }\end{array}$} & \multicolumn{5}{|c|}{ Exposure Routes and Hazards } \\
\cline { 2 - 6 } & Direct Radiation & Inhalation & $\begin{array}{c}\text { Operation } \\
\text { Hazards }\end{array}$ & $\begin{array}{c}\text { Construction } \\
\text { Hazards }\end{array}$ & $\begin{array}{c}\text { Nonroutine } \\
\text { Events }\end{array}$ \\
\hline $\begin{array}{c}\text { Treatment: } \\
\text { Facility operators }\end{array}$ & $\bullet$ & $\bullet$ & & - & $\bullet$ \\
\hline $\begin{array}{c}\text { Handling, Storage, Disposal: } \\
\text { Equipment operators } \\
\text { Laborers }\end{array}$ & $\bullet$ & $\bullet$ & $\bullet$ & - & $\bullet$ \\
\hline Construction workers & $\bullet$ & $\bullet$ & $\bullet$ & - & - \\
\hline
\end{tabular}

- = Applicable exposure route

$-=$ Non-applicable exposure route

Generally, larger, more efficient facilities can process more waste with fewer workers per volume processed than smaller facilities. Staffing requirements for various sized facilities are estimated using a linear regression analysis. The resulting equations which predict FTEs based on facility throughput, are based on data points consisting of facility throughputs and the associated number of FTEs required for each module. These data points are provided by EG\&G (Sherick, M., EG\&G, fax of data package to R. Phillipi, ORNL, June, 1994). 
If the estimated throughput for a module falls below the range of throughput values used to develop the regression equations that predict FTEs, the following equation (data package from D. Shropshire, EG\&G, to P. Pehlman, ORNL, April 22, 1994) is used to estimate the number of FTEs:

where

$$
\text { Number of FTEs }=\left(\frac{T P}{T P_{\min }}\right)^{0.7} * F T E_{\min }
$$

TP $\quad=$ estimated module throughput $\left(\mathrm{m}^{3} / \mathrm{hr}\right)$

$\mathrm{Tp}_{\min } \quad=$ minimum module throughput $\left(\mathrm{m}^{3} / \mathrm{hr}\right)$

FTE $_{\min }=$ number of FTEs associated with the minimum module throughput value

If the estimated throughput for a module is larger than the range of throughput values used to develop the regression to predict FTEs, the following equation (data package from D. Shropshire, EG\&G, to P. Pehlman, ORNL, April 22, 1994) is used:

where

$$
\text { Number of FTEs }=\left(\frac{T P}{T P_{\max }}\right)^{0.7} * F T E_{\max }
$$

TP $\quad=$ estimated module throughput $\left(\mathrm{m}^{3} / \mathrm{hr}\right)$

$\mathrm{Tp}_{\max } \quad=$ maximum module throughput $\left(\mathrm{m}^{3} / \mathrm{hr}\right)$

FTE $_{\max }=$ number of FTEs associated with the maximum module throughput value

FTEs required for construction of facilities were also estimated using this approach.

The computed number of FTEs are then multiplied by the duration of the process to yield the number of person-hrs required for each worker type. For the PEIS, it is assumed that the facilities operate at $70 \%$ availability (i.e., $30 \%$ of the time the facilities are not operating or are under maintenance). The worker is assumed to be exposed for $5.6 \mathrm{hr} / \mathrm{d}$ or $1,344 \mathrm{hr} / \mathrm{yr}(240 \mathrm{~d} / \mathrm{yr})$ to the treatment or handling process (EG\&G, 1992).

\subsection{ESTIMATION OF DOSES AND INTAKES: INHALATION}

The inhalation exposure route is evaluated for treatment and storage unless workers are separated from the source by airlocks. Inhalation is not evaluated for post-treatment storage or disposal activities, since waste containers are assumed to be sealed and decontaminated. Doses and intakes of radionuclides and chemicals are calculated by estimating an air concentration for each contaminant using a generalized ventilation room model (Jayjock, 1988). The room model takes into account air exchange rates (ventilation rates), air mixing, and emission rates of contaminants for particular TSD activities. Intake and dose estimation are described in the following sections. 


\subsubsection{Air Concentrations}

Estimation of air concentrations is necessary to obtain risks via inhalation. Air concentrations are estimated for situations involving fugitive emissions and handling activities. For fugitive emission modeling, a ventilation room model is used. For handling activity modeling, air concentrations are estimated by assessing the resuspension of surface contamination from drums or casks. The contaminant air concentrations are compared to regulatory limits, such as the threshold limit values (TLVs) for chemicals and derived air concentrations, (DACs) for radionuclides. The computed air concentrations are compared to $10 \%$ of the DAC value for each radionuclide and to the TLV for each chemical contaminant. If the computed contaminant air concentration is greater than the regulatory limit, then the limit is used to compute doses (DOE, 1992). Estimation of air concentrations from fugitive emissions and waste handling activities is discussed in the following subsections.

\subsubsection{Fugitive Emissions During Treatment}

Fugitive emissions are leaks of gaseous or particulate contaminants from equipment through valves, pipes, or seals. Indoor scenarios are commonly used for WM workers laboring inside WM facilities. For indoor modeling, air concentrations are estimated by the use of a generalized ventilation room model (Jayjock, 1988; Jayjock, 1993; ORNL, 1995b). It is assumed that the contaminant releases are distributed evenly throughout the entire volume of the room or work area. Intakes or doses from inhalation are estimated for each module, each contaminant, and each worker type. Since the exact amount of leakage from equipment is not available without performing a process analysis on each potential module, it is assumed that fugitive emissions are released within the treatment module at a rate equal to $10 \%$ of the stack emission rate (EPA, 1988; EPA, 1989). The unit air concentrations, intakes, and doses are calculated based on the following equation (EPA, 1991):

$$
A C=\left(\frac{E R * 0.1}{Q * P}\right)
$$

where

$$
\begin{array}{ll}
\mathrm{AC} & =\text { air concentration }\left(\mathrm{Ci} / \mathrm{m}^{3} \text { or } \mathrm{g} / \mathrm{m}^{3}\right) \\
\mathrm{ER} & =\text { stack emission rate }(\mathrm{Ci} / \mathrm{s} \text { or } \mathrm{g} / \mathrm{s}) \\
\mathrm{Q} & =\text { ventilation rate }\left(1.42 \mathrm{~m}^{3} / \mathrm{s}\right) \\
\mathrm{P} & =\text { mixing factor }(0.7)
\end{array}
$$




\subsubsection{Handling Activities}

Air concentrations are also calculated for resuspension of radioactive contamination on the surface of drums or casks. Exposure to resuspended surface contamination, for the receiving and inspection module during unloading and storage of the drums and casks, may pose a risk to drum and cask handlers and forklift drivers. The buildup of waste containers in lag storage varies depending on the capacity of the receiving and inspection module. Ten percent of the drums or casks are considered to have surface contamination that is resuspended during receiving activities (DOE, 1990). It is assumed that once the waste is treated and packaged or prepared for offsite shipment, the drums are decontaminated and free of surface contamination.

To compute air concentrations due to resuspension of radionuclide particulates, it is assumed that each radionuclide inside the waste container (drum or cask) is also present on the outside of the container at the limit indicated in table 2-2 of the DOE Radiological Control Manual (DOE, 1992). One exception is tritium, which is assumed to have already evaporated. A resuspension factor of $1 \mathrm{x} 10^{-6} / \mathrm{m}$ $\left(\left[\mathrm{Ci} / \mathrm{m}^{3}\right] /\left[\mathrm{Ci} / \mathrm{m}^{2}\right]\right)$ is used based on experimental data from resuspension of plutonium surface contamination (DOE, 1990).

\subsubsection{Intakes and Doses}

Unit intakes or doses (i.e., EDEs) can be determined from the computed contaminant air concentrations. The equations used to estimate chemical intake via inhalation are presented in ORNL (1995b).

An inhalation rate of $0.8 \mathrm{~m}^{3} / \mathrm{hr}$, corresponding to a light activity level, is chosen for workers because waste processing activities are not generally strenuous and may often be remote operations. The averaging time for carcinogenic chemicals is assumed to be $18,250 \mathrm{~d}$ ( $365 \mathrm{~d} / \mathrm{yr}$ for $50 \mathrm{yr}$ ). For noncarcinogens, the averaging time equals the exposure duration. Body weight is assumed to be that of an average adult male (i.e., $70 \mathrm{~kg}[154 \mathrm{lb}]$ ).

Intakes of radionuclides via inhalation are determined by the equations presented in ORNL (1995b). Intake is estimated for each chemical carcinogen and noncarcinogen, and a dose is estimated for each radionuclide. These intakes and doses are combined with toxicity values to estimate risks, as explained in the following sections and in ORNL (1995b).

\subsection{Estimation of Doses: Direct Radiation}

Doses received from exposure to penetrating external radiation are calculated by taking into account the capacity of each module, worker types, number of FTEs, exposure durations, and available shielding. 
With the aid of the MicroShield computer code (Grove Engineering, 1992), a "unit" EDE rate, based upon a unit inventory $(1 \mathrm{Ci}$ ) of each radionuclide present in the module, is calculated for workers within each module. Source geometries, shielding geometries, and source-to-receptor distances are determined and used as input into MicroShield to estimate the unit EDE rates.

Unit EDE rates are estimated by modeling each module and varying the shielding and waste type in each module. Three shielding configurations are used in the modeling process. For handling activities involving contact-handled waste containers, the worker is assumed to be $1 \mathrm{~m}$ (1.1 yd) away from the source (e.g., drum) with air providing some shielding. For treatment activities, the worker is assumed to be located in an operating gallery behind a 30-cm (12-in) concrete wall (EG\&G, 1992). For remote-handled waste, the worker is assumed to be located within an operating gallery behind a $1-\mathrm{m}$ (1.1 yd) concrete shielding wall (EG\&G, 1993). Various air shields are considered between the worker and process equipment, waste containers, and shielding walls (ORNL, 1995b). More information on shielding assumptions is provided in attachment $\mathrm{A}$.

The contaminant concentrations in a given waste type are multiplied by the module capacity to obtain the radionuclide inventories present in the module. These radionuclide inventories in the module are multiplied by the computed unit EDE rates to yield a dose rate for the module. For those modules (e.g., shredding, evaporation, solidification, vitrification, and incineration) that vary in capacity with facility size and processing rate, each unit EDE rate is calculated based on a $1-\mathrm{m}^{3}\left(1.3-\mathrm{yd}^{3}\right)$ module size. The computed dose rate is adjusted to account for the actual size of the module required to process the waste volume and to reflect the additional "self-shielding" provided by larger waste volumes.

Adjustment factor equations were generated to estimate the change in the EDE rate resulting from increased vessel size while the amount of waste in the vessel remains constant $\left(1 \mathrm{~m}^{3}\left[1.3 \mathrm{yd}^{3}\right]\right)$. Four general types of source geometries were modeled to represent the configuration of all WM modules: (1) steel cylindrical sources (e.g., tanks, vessels), (2) steel cylindrical sources lined with refractory brick (e.g., incinerators), (3) steel rectangular sources (e.g., shredders), and (4) concrete rectangular sources (e.g., decontamination booths). Each geometry has a different adjustment factor equation used in modifying the unit dose rate to reflect the actual module capacity (vessel size).

The adjusted module dose rate is multiplied by the number of FTEs and respective exposure durations to yield the dose (person-mrem) for each worker type for a given module. These doses by worker type are then used to calculate risks for each worker type. Radiation exposure limits outlined in DOE Order 5480.11, DOE Order 6430.1A, $10 \mathrm{CFR} 835$, and the administrative limits outlined in the DOE Radiological Control Manual are assumed to be the upper bounds of allowable worker exposure to radiation. 


\subsection{RisK ESTIMATION}

WM workers are potentially at risk from exposure to contaminants, from physical trauma due to construction and operation hazards, and from external events or waste handling nonroutine events. Estimation of these risks is discussed in the following subsections.

\subsubsection{Risks From Exposure To Contaminants}

Risks for each module and exposure route are estimated using the doses and intakes derived for each worker type. For the inhalation exposure route, carcinogenic chemical intakes are used to calculate risks using the following equation:

$$
R_{c}=I \times C P F
$$

where:

$$
\begin{array}{lll}
\mathrm{R}_{\mathrm{c}} & =\text { risk per carcinogenic chemical } \\
\mathrm{I} & =\text { intake }(\mathrm{mg} / \mathrm{kg} \cdot \mathrm{d}) \\
\mathrm{CPF} & =\text { cancer potency factor }(\mathrm{mg} / \mathrm{kg} \cdot \mathrm{d})^{-1}
\end{array}
$$

The cancer potency factors for workers are obtained from EPA's IRIS or HEAST. For radionuclide inhalation, cancer incidence risks, cancer fatality risks, and adverse genetic effects are calculated using the following equation:

$$
R_{c}=E D E \times R F
$$

where:

$\mathrm{R}_{\mathrm{c}} \quad=\quad$ risk per radionuclide

$\mathrm{EDE}=$ effective dose equivalent or dose (rem)

$\mathrm{RF}=$ risk factor for cancer incidence, fatality, and genetic effects (risk/rem) 
For inhalation of noncarcinogen chemicals, an $\mathrm{ER}_{\mathrm{w}}$ is calculated by comparing the estimated air concentration (see equation 3.3) to occupational limits (e.g., TLVs). The comparison equation for an $\mathrm{Er}_{\mathrm{w}}$ is shown below:

$$
E R_{w}=\frac{A C}{T W A-T L V}
$$

where:

$$
\begin{aligned}
& \mathrm{ER}_{\mathrm{w}}=\text { exposure ratio } \\
& \mathrm{AC}=\text { air concentration }\left(\mathrm{g} / \mathrm{m}^{3}\right) \\
& \text { TWA-TLV }=\text { time-weighted average threshold limit value }\left(\mathrm{mg} / \mathrm{m}^{3}\right)
\end{aligned}
$$

For direct radiation risks resulting from exposure to external radiation, the worker EDEs are multiplied by ICRP 60 risk factors to yield the risks for each module and worker type as explained in more detail in ORNL (1995b).

For inhalation risks resulting from nonroutine event conditions, an immediately dangerous to life and health (IDLH) index is computed using the same method as for that of the exposure index, that is, using the IDLH concentration instead of the TLV (ORNL, 1995b).

For nonroutine event conditions involving radionuclides, exposure may occur by inhalation and external radiation from immersion in a contaminated plume. Air concentrations of radionuclides can be used to calculate external doses due to immersion using EPA dose equivalent coefficients (EPA, 1993a; ORNL, 1995b).

Risks are determined for each contaminant and summed to obtain population risk for each exposure route for a given module. Individual risks can be determined by dividing the total number of person-hrs by the number of workers required for the TSD activity. In general, it is assumed that one FTE is equivalent to one individual. An exposure ratio is determined for each noncarcinogenic chemical. All exposure ratios are summed to yield an exposure index for each module.

Once risks have been determined for each module, the risks for modules that comprise an entire waste treatment process are summed to yield the risks from processing a waste type at a given TSD facility. These risks are summed according to risk type (i.e., cancer incidence, cancer fatality, and genetic effects). The highest exposure index (by module) is chosen to represent the entire treatment process. 


\subsubsection{Risks From Physical Trauma}

In addition to exposure-related risks, workers face safety hazards from construction and routine operations at TSD facilities. The WM worker evaluation includes injuries and fatalities from construction and operational hazards. Operational hazards occur during the operation (not construction) of a facility and do not involve the release of contaminants. For example, operational hazards include being injured by a falling drum or getting a hand caught in a piece of equipment. Construction and operation risk factors are the same for every module since they are based on risk rates from the literature as discussed in ORNL (1995b).

\subsubsection{Installation-wide Risk Estimation}

The installation-wide worker risk can be obtained by summing the risks for each treatment process that occurs at an installation. Complex-wide WM worker risk can be obtained by summing the installation-wide WM worker risks. In the case of noncarcinogenic chemicals, where exposure indices are computed, the highest index value is presented.

\subsection{NONROUTINE EvENT SCENARIOS}

Nonroutine events are usually of short duration and include such incidences as fire, equipment failure, structure collapse, and other nonroutine events. Nonroutine event risks are computed using the same equations as for routine operations. Exposures resulting from these types of occurrences can also be estimated by the steps outlined in this methodology.

The critical parameters for assessing risks attributed to nonroutine events are condition-specific exposure durations, amount of contaminant released during the nonroutine event (e.g., amount estimated to volatilize during a fire or explosion), and distances of workers from the event scene.

The primary types of nonroutine events that are evaluated for WM workers are operational nonroutine events, waste handling nonroutine events, and severe external events. Operational nonroutine events are those that result from processes and activities involved in facility operation and may include a wide range of nonroutine events posing potentially adverse consequences to the workers. In the PEIS, these nonroutine events include fires propagating to the filtration systems of treatment facilities and explosions in treatment facilities. Waste handling nonroutine events may occur when moving containers to and from storage facilities. These waste handling nonroutine events may involve gaseous releases, spills, and events involving solid waste material. External events include aircraft crashes and earthquakes leading to fires in treatment and storage facilities. Source terms and nonroutine event scenarios are provided by ANL for the PEIS analysis. 
The workers evaluated for nonroutine events are those immediately involved (e.g., forklift operator or waste handler who drops a waste container) and those workers within the facility. One shift of workers is assumed to be in the facility when the nonroutine event occurs.

\subsubsection{Operational Nonroutine Events}

The types of operational facility nonroutine events evaluated in the PEIS include fires within the treatment and storage facilities and incinerator explosions. Facility fires and explosions are assumed to result in loss of facility filtration (i.e., a ground-level release) with the exception of incinerator explosions where the HEPA filtration efficiency remains at $99.9 \%$. In the incinerator explosion scenario, workers inside the facility would be exposed to an air concentration 1,000 times higher than that leaving the facility.

Treatment and storage facility nonroutine events involve the following assumptions:

- Workers are assumed not to be blocked or injured by falling or burning debris or to be overcome by heat or smoke to such an extent as to impair their escape from the scene. Risks are based upon exposures only.

- Treatment facility nonroutine events result in releases into the operating gallery where workers are located. An exposure duration of one minute is assumed to allow for the time it takes for the workers to leave the scene and avoid any obstructions. Half of the operating gallery ( $32 \mathrm{~m} \mathrm{[35} \mathrm{yd]} \mathrm{long} \mathrm{x} 6 \mathrm{~m}$ [6.6 yd] wide $\mathrm{x} 6 \mathrm{~m}$ [6.6 yd] high ) is assumed to fill with contaminated air.

- For storage nonroutine events involving external initiators (e.g., fires, explosions), the release is assumed to cause a storage cell or bay (12 $\mathrm{m}$ [13 yd] long $\mathrm{x} 18 \mathrm{~m}$ [20 yd] wide x $6 \mathrm{~m}$ [6.6 yd] high) in the storage facility to fill with contaminated air.

- No ventilation is assumed when assessing impacts to workers from treatment or storage nonroutine events.

\subsubsection{Waste Handling Nonroutine Events}

The waste handling nonroutine event scenarios may consist of dropping containers onto ground surfaces with the contents being released or puncturing containers with a forklift in the storage or staging areas. The amount released and resulting consequences are based on the container contents, operating facility systems, and worker placement relative to the released material. 
Waste handling nonroutine event analyses involve the following assumptions:

\section{Indoor Scenario:}

- It is not credible to assume that the release from a simple (not pressurized or explosive) spill would distribute within the entire volume of a facility; therefore, it is assumed that the material distributes within a hemispherical volume of limited size surrounding the container.

- To estimate the exposure duration, it is assumed that the worker is located $1 \mathrm{~m}$ (1.1 yd) from a spill and immediately leaves the area. This person leaves the area at a rate of $1 \mathrm{~m} / \mathrm{s}$ (MMES, 1992). If the computed duration is less than one minute, then one minute may be used for a more conservative estimate.

\section{Outdoor Scenario:}

- For outdoor waste handling nonroutine events that are visibly detectable, such as spills accompanied by fire or explosion, a five-minute exposure duration is assumed. For spills that would not necessarily be readily detected visibly, a 10 -minute exposure period is assumed.

- Outdoor air concentrations are calculated using the INEXPLC code (a QuickBASIC program) for closein atmospheric dispersion (Bloom, 1993). The following are modeling assumptions for the PEIS: (1) the worker is standing directly downwind of release, (2) the release height is zero or at ground level, (3) the receptor height is $1.5 \mathrm{~m}$ (1.6 yd), and (4) the radius of the source is $1.5 \mathrm{~m}$ (1.6 yd).

- Receptor distances are varied from $1 \mathrm{~m}$ (1.1 yd) to $25 \mathrm{~m}$ (27 yd) in 1-m (1.1-yd) increments. Concentrations are calculated at each distance. An average of these concentrations is used as an estimate of the exposure concentration.

- As with indoor handling nonroutine events, it is assumed that no further exposure occurs after the worker leaves the contaminated volume of air.

\subsubsection{External Events}

Safety Analysis Reports (SARs) prepared for specific facilities take into account consequences that can result from credible natural phenomena and operational nonroutine events. For the PEIS, an earthquake is the natural phenomenon considered as credible. Other external events include an aircraft hitting the storage or treatment facility. 
Natural phenomena may be capable of acting as initiators of major nonroutine events at nuclear facilities (LLNL, 1986). These events should be evaluated for their capability of disrupting the facility confinement system and triggering other failures and for their contribution to contaminant dispersal beyond the facility. Assumptions regarding the amount of material that is released should be consistent with the amount released by other events causing damage to the confinement system during operational events (LLNL, 1986).

The events triggered by an earthquake are assumed to be fires and explosions. The facilities involved in incineration and waste storage are evaluated. It is assumed that the confinement system is breached and the engineered safety features are inoperable. Maximum air concentrations are estimated, since it is assumed that the ventilation system would not function if the resulting fires and explosions were indoors.

The risk of release of radioactive and hazardous materials caused by an aircraft crashing into a facility increases with proximity to an airport (LLNL, 1986). Assumptions regarding the amount of material that is released should be consistent with the amount released by other events causing damage to the confinement system, such as natural phenomena and operational events (LLNL, 1986). In particular, the crash is assumed to result in fire and explosion.

Treatment and storage facility nonroutine events due to external events involve the same assumptions as those listed in section 3.6.1 for operational nonroutine events.

\subsection{ASSUMPTIONS AND UNCERTAINTIES}

The assumptions and uncertainties described in this section for WM workers are divided into three categories: model uncertainties, scenario uncertainties, and parameter uncertainties.

\subsubsection{Model Uncertainties}

Two models are used for the WM worker risk evaluation: MicroShield and a room model (ORNL, 1995b). Models are designed to handle certain scenarios which may or may not accurately represent the circumstances at a WM facility. The use of these models may contribute to the uncertainty of the risk assessment.

MicroShield (Grove Engineering, Inc., 1992) dose rate calculations are based on Gaussian quadrature numerical solutions of the point kernal equation for the exposure scenario entered into the computer code. Although the Gaussian quadrature numerical method of integration provides solutions to the point kernal equation, limitations of the program such as the modeling of buildup, MicroShield's underestimation of dose rate for cases where radiation passes through the shield at a large oblique angle, and the inability of 
the code to model back-scatter from materials beyond the dose point, result in systematic uncertainties in MicroShield dose rate calculation. The authors of the code estimate this uncertainty to be approximately $10 \%$. In this health risk assessment, exposure scenarios have been derived to minimize uncertainties due to the limitations of the program. This was accomplished by selecting the proper shield material to model buildup and by defining geometries that eliminated oblique angles from the path traversed by radiation in passing through shield material. Back-scatter was not thought to contribute significantly to the dose rate unless the worker was enclosed in a contaminated area such as a storage tank or contaminated structure.

The MicroShield model estimates the exposure to WM workers due to gamma radiation. A radioactive decay time of $5 \mathrm{yr}$ is used to incorporate the effects of daughter products into the exposure rate. The density and elemental composition of shielding materials were approximated using MicroShield's default materials. For example, the elemental composition of iron is used to model steel shielding (iron content in steel is approximately $98 \%$ ).

The room model assumes that particulates are not deposited onto structural and equipment surfaces (as they would be in an actual situation). Particulates are assumed to be completely available for inhalation. This assumption results in a conservative risk estimate.

\subsubsection{Scenario Uncertainties}

For WM workers, several scenario uncertainties stem from assumptions or professional judgement. For example, the estimated number of workers or FTEs is based partially on professional judgement. Worker configurations are based on conversations with contacts at sites where particular technologies are performed, conversations with engineers who are familiar with the technologies, EPA guidance, and waste processing manuals. Source-to-receptor distance assumptions are also based on this information. The source-to-receptor distances are typically small. If a WM worker is closer or farther from the source than the assumed distance, an overestimation or underestimation of risk may result.

\subsubsection{Parameter Uncertainties}

For WM workers, parameter uncertainties include errors associated with waste capacity and waste volume percentages for each module, although the volumes and percentages are based upon values in the literature. There is necessarily some uncertainty in the assumptions required to estimate WM worker risks for waste handling at facilities that have not yet been built. However, these assumptions are made systematically (i.e., for all installations in the DOE complex) and should not strongly influence the results of a comparative, relative risk analysis such as the PEIS. 
ATTACHMENT A 


\section{A. WASTE MANAGEMENT WORKER ACTIVITIES AND MODULES}

TSD operations are categorized into specific processes, or WM modules, that can be interchangeably arranged to form a "treatment train." Worker risk can be estimated for any combination of WM modules chosen for the TSD of a given waste type using the WM unit dose approach described in chapter 3 of this document. The WM modules being used to evaluate worker risk for the PEIS are based on generic facility design modules. The purpose of this attachment is: (1) to discuss the modular approach to treatment trains, (2) to discuss the WM worker types and their environments under consideration in the PEIS, and (3) to identify and describe the WM modules under consideration in the PEIS. This attachment presents the major TSD processes considered in the PEIS human health risk evaluation, however, it is not intended to present all possible waste facility configurations, modules, and worker types.

\section{A.1 Treatment Trains: Modular Approach}

WM modules are self-contained waste handling or treatment processes where workers are located to treat or handle waste as it is processed through a facility (e.g. receiving and inspection, incineration, packaging). The module houses the process and serves conceptually as a "box" within which worker exposures may occur. Certain worker types are assumed to be associated with each WM module. A facility can contain only one module or several modules and a single module may contain several subactivities (or submodules). The modules are based on conceptual designs formulated by EG\&G, for the WM facility costing for the PEIS (EG\&G, 1992, 1993, 1994). WM treatment modules can be put together to form a "treatment train," which includes all modules necessary to treat a specific waste stream. Treatments differ among the waste streams; therefore, each waste stream may require a different set of modules. The WM treatment modules are generically designed so that they can be interchanged between treatment trains. Examples of a WM treatment train and a WM facility are shown in figures A.1-1 and A.1-2, respectively. 


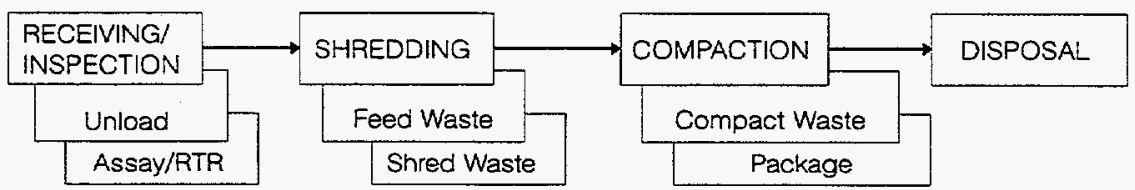

Figure A.1-1. Conceptual Illustration of a Treatment Train.

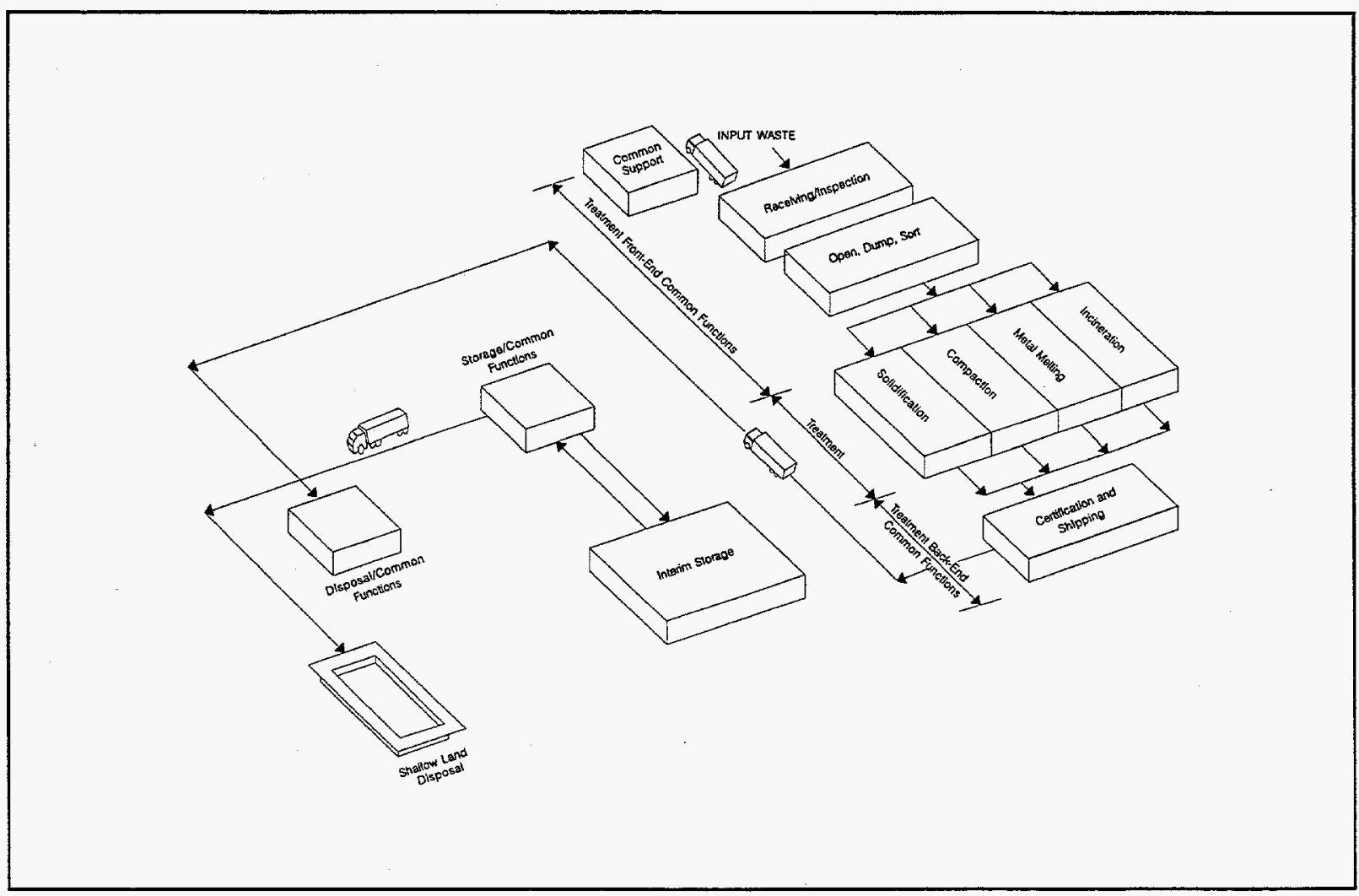

Source: EG\&G, 1992

Figure A.1-2. Illustration of a Waste Management Facility. 


\section{A.2 WM WORKER ENVIRONMENT AND WORKER TYPES}

Worker activities within WM modules can be grouped into two general types of exposure environments: waste handling operations and treatment facility operations. Worker exposure and protection vary according to activity and environment. Worker types and activities for the two types of worker environments are presented in table A.2-1.

Table A.2-1. Waste Management Activity Types and Worker Types

\begin{tabular}{||l|l|l||}
\hline \multicolumn{1}{|c|}{$\begin{array}{c}\text { Worker } \\
\text { Environments }\end{array}$} & \multicolumn{1}{|c|}{ Activity Types } & \multicolumn{1}{c|}{ Worker Types } \\
\hline \multirow{3}{*}{$\begin{array}{l}\text { Waste Handling } \\
\text { Operations }\end{array}$} & $\begin{array}{l}\text { Handling (e.g., receiving/inspection, } \\
\text { shipping/certification) }\end{array}$ & $\begin{array}{l}\text { equipment operators (forklift, } \\
\text { crane) laborers }\end{array}$ \\
\cline { 2 - 3 } & Storage (e.g., interim storage) & $\begin{array}{l}\text { equipment operators (forklift, } \\
\text { crane) laborers }\end{array}$ \\
\cline { 2 - 4 } & $\begin{array}{l}\text { Disposal (e.g., shallow land burial, } \\
\text { tumulus, below-ground vault) }\end{array}$ & $\begin{array}{l}\text { equipment operators (forklift, } \\
\text { crane) laborers }\end{array}$ \\
\hline Facility Operations & $\begin{array}{l}\text { Treatment (e.g., size reduction, } \\
\text { compaction, decontamination, } \\
\text { evaporation, solidification, etc.) }\end{array}$ & facility operators \\
\hline
\end{tabular}

Waste handling can occur indoors or outdoors and involves activities such as retrieving containers from storage, unloading containers from trucks, and placing containers in storage or disposal. During handling activities, workers may be in close proximity to the waste containers, or they may use cranes or remotely operated equipment to handle containers of high activity waste (Wagner et al., 1987). The distance from the source to the workers varies from $1-15 \mathrm{~m}$ (1.1-16 yd) depending on the handling activity.

In the treatment facility environment, worker activities include operation of the various machines and process equipment necessary to treat the waste. In keeping with the conceptual WM facility module designs, it is assumed that workers are located in operating "galleries" (EG\&G, 1992). An operating gallery is a room in the treatment facility, located separately from those rooms in which waste processing takes place. Operating galleries contain the treatment process controls, viewing windows, and/or video screens that allow workers to observe the treatment process. The amount of worker protection, or shielding, provided by the operating gallery varies by facility depending on the type of waste being treated. For example, concrete shielding walls and air locks may be present to minimize external and internal radiation exposure, respectively. 
Depending on the facility type specified for a particular waste stream (e.g. LLW), the appropriate facility shielding configuration is used for each WM treatment module. For a given PEIS alternative, these same assumptions are applied at each site. These shielding criteria were used to maintain consistency and simplicity in the PEIS comparative analyses, but are not meant to represent all possible shielding configurations at DOE facilities. The generic shielding assumptions for the various WM facility types are presented below in table A.2-2.

Table A.2-2. Facility Types and Shielding/Worker Protection Characteristics

\begin{tabular}{||l|l||}
\hline \multicolumn{1}{|c|}{ Facility Type } & \multicolumn{1}{|c|}{ Shielding/Worker Protection Characteristics } \\
\hline non-alpha facility & $\begin{array}{l}2-\mathrm{m}(2.2-\mathrm{yd}) \text { air from source to 30-cm (12-in)-thick concrete } \\
\text { wall; 1-m (1.1-yd) air from wall to receptor; no air locks } \\
\text { present }\end{array}$ \\
\hline alpha facility & $\begin{array}{l}2-\mathrm{m}(2.2-\mathrm{yd}) \text { air from source to 30-cm (12-in)-thick concrete } \\
\text { wall; 1 m (1.1 yd) air from wall to receptor; air locks present }\end{array}$ \\
\hline remote facility & $\begin{array}{l}2-\mathrm{m}(2.2-\mathrm{yd}) \text { air from source to 1-m (1.1-yd)-thick concrete } \\
\text { wall; 1-m (1.1-yd) air from wall to receptor; air locks present }\end{array}$ \\
\hline
\end{tabular}

Source: EG\&G, 1992; 1993; 1994.

\section{A.3 Waste Management Modules}

For the purposes of the PEIS worker risk analysis, WM activities consist of 32 basic modules. To simplify worker exposure modeling, only the main worker tasks or treatment operations are considered to represent each module. These are designated "submodules" and may include the most common worker activities, the predominant treatment operations, and/or the largest sources of exposure. A module may also be a submodule of another. For example, the packaging module can stand alone or may be a submodule of solidification. The purpose of this section is to identify and describe these 32 modules and some of their submodules. The number of workers required to operate each module depends upon facility size and throughput rate, which vary with consolidation alternative.

\section{A.3.1 Receiving/inspection}

- Submodules: assay/real-time radiography (RTR)

unload drum or cask or TRUPACT from vehicle 
The receiving/inspection module usually occurs on the front end of a treatment train. Receiving and inspection is generally performed in a facility equipped to receive waste containers that arrive via a transport vehicle and which has a staging/storing area to permit inspection. Containers are unloaded in an enclosed truck bay and placed in an indoor staging area where they are inspected (EG\&G, 1992).

This module consists of two submodules, or operation units: unload drum, cask, or TRUPACT and assay/RTR. Waste containers usually arrive on flat-bed trailers or van trucks from which the containers may be unloaded with a 20-ton bridge crane and/or a 5-ton forklift truck (EG\&G, 1992). Upon removal from the transport vehicle, the containers are placed in a staging/storage area where they are visually examined, labeled, logged, recorded, and sent to inspection and assay. The purpose of the assay/RTR unit operation is to physically and radiologically characterize the waste to allow segregation of the containers according to their treatment needs (EG\&G, 1992). The containers are weighed and measured to determine density and then undergo a nondestructive inspection, such as RTR, to determine the contents. In the RTR classification technique the waste containers are transported in and out of the enclosure on a cart and turntable assembly and an x-ray source and imaging system housed in a lead-shielded, light-tight enclosure (to keep radiation levels low) is used to display the image of the object(s). After examination is completed, the containers are moved either directly to treatment or to storage, or may be returned to their origin if the facility cannot accommodate the identified waste type.

\section{A.3.2 Sorting}

- Submodule: sort solid waste on conveyor

In the sorting module, waste is grouped according to waste type and treatment requirements. Sorting is typically the initial step in the treatment process. After wastes are characterized and verified, some of the waste is repackaged and shipped to be treated at other facilities. Solid waste containers are opened and their contents are dumped onto conveyors or sorting tables. Solid waste can be sorted manually or mechanically from an operating gallery.

\section{A.3.3 Size Reduction (shredding)}

- Submodules: feed waste bin

shredder operation

Shredding is a size reduction technique commonly used before packaging of waste for disposal or as a precursor to other treatment modules. By changing the shape of waste, such as wood, paper, or some metals, this method reduces the space occupied by wastes, which facilitates feeding wastes into other treatment modules, such as compaction or incineration. Shredding occurs in a facility equipped with a dust 
collection and filtration unit to treat air containing fugitive dust from the shredding operations (EG\&G, 1992).

\section{A.3.4 In-drum Compaction}

- Submodules: compactor operation

packaging/drum handling

In-drum compaction is a method of physically compressing material into a smaller volume. Using this volume reduction method, waste is compacted directly into 55-gal drums. Drum compactors usually consist of a hydraulically operated ram, a support frame, and an air filtration system containing roughing filters and/or HEPA filters (ANL, 1995a). The volume reduction obtained from compacting waste depends on the applied force, the bulk density of the waste material, and the spring-back of the material when pressure is released (Trigilio, 1981).

Loose compactible waste (such as paper, plastic, filters, and glass) is placed into the drum and compacted by a ram. This process is repeated until the drum is approximately one-third full, at which point an antispringback device is secured into the container (LLNL, 1992). Each third of the container is filled in this manner, and after the third anti-springback device is incorporated, the container lid is installed (LLNL, 1992). The drum or box compactor does not generate any liquid residuals because waste with free liquids is excluded from compaction (ANL, 1995a). An illustration of a conceptual compactor system configuration is shown in figure A.3-1. 


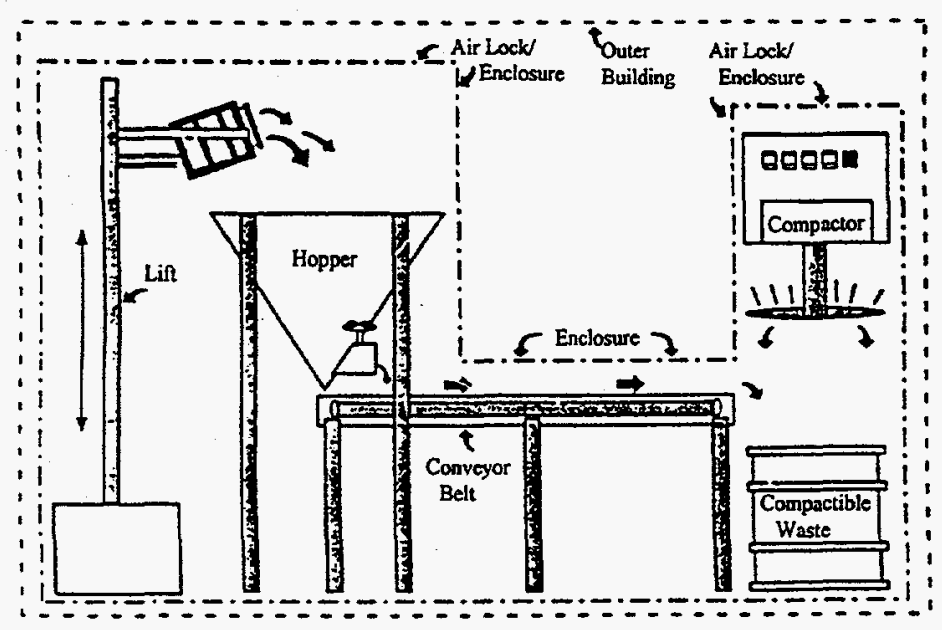

Source: LLNL, 1992.

Figure A.3-1. Conceptual in-drum compactor operation.

\section{A.3.5 Supercompaction}

- Submodules: supercompactor operation packaging/drum handling

Supercompaction is a volume reduction technique by which filled drums (or boxes) are compressed and placed in overpacks for disposal. A drum is moved by conveyor into the press negative pressure environmental chamber where a device pierces the drum to release any trapped gases before a high pressure compactor compresses the drum (EG\&G, 1992). No liquid discharge should occur since only solid materials undergo supercompaction. After compaction, a lift device places the compressed drum into an overpack that is sealed and washed once it is full (EG\&G, 1992). 


\section{A.3.6 Shredding/compaction}

- Submodules: feed waste bin

shredding

compaction

packaging/drum handling

The major submodules used in the shredding/compaction module are shredding and compaction. Size reduction by shredding before compression tends to increase the volume reduction achieved by compaction by about $10 \%$ with some materials (LLNL, 1992). After shredding, an in-drum compaction or the supercompaction process (described above) is used to further reduce waste volume.

\section{A.3.7 Evaporation}

- Submodule: evaporator operation

Evaporation is a technique used to separate water from contaminants and for volume reduction of liquid radioactive wastes. Evaporation is conducted by vaporizing the water to produce a concentrated solution or thick liquor of contaminated material (ANL, 1995a). The vaporized water can be condensed and reused in process applications or can be discharged (Magleby, 1988). This method is most effective on solutions already having relatively high concentrations of impurities (ANL, 1995a).

Most evaporators are heated by low pressure steam (such as from a low pressure boiler) condensing on the outer surface of metal tubes (ANL, 1995a). In most cases, the material to be evaporated flows inside the tubes and a bleed stream is continuously purged to remove the concentrated product from the evaporator (ANL, 1995a). The concentrate remains in a fluid-like form and may require further treatment, such as solidification, before final disposal (ANL, 1995a).

\section{A.3.8 Decontamination}

- Submodules: shredding

decontamination

compaction

packaging/drum handling

Decontamination is the process of cleaning surface-contaminated equipment or objects to reduce or eliminate radiation traces. To facilitate the handling or reuse of these materials, a wide variety of decontaminating agents and procedures is available to remove surface and entrained contamination. The 
kind of decontamination used depends upon the type, size and shape of the material, as well as the nature of the contamination (EG\&G, 1993). The most common decontamination methods include high-pressure water spraying (also called hydrolasing or hydroblasting), liquid abrasive blasting, chemical decontamination, electropolishing, and simple washing. Each of these methods generally works by sloughing off the surface contaminants. The type of decontamination process considered in the PEIS is a blasting booth made of concrete block with jets in the walls. Decontamination generates additional volumes of waste which must be collected and pumped to a liquid waste treatment unit (EG\&G, 1993).

The major steps that may be used in decontamination are shredding, decontamination, compaction, and drum handling. It may be necessary for some wastes to undergo shredding (or size reduction) before decontamination to facilitate handling and/or to expose all surfaces. The residual waste after decontamination may then be collected for further treatment, such as compaction. As each drum-full of waste is accumulated, the drums are maneuvered to the next station or module. This entire process is performed indoors.

\section{A.3.9 Solidification}

- Submodules: solidification

packaging/drum handling

Solidification is the process of converting wastes into a solid mass. Before solidification, the waste can be in a variety of forms, such as liquid, slurry, sludge, or dry solid particles (ANL, 1995a). Solidification is achieved by mixing the waste with a solidification agent, most commonly cement (usually Portland cement), or sometimes bitumen or extruded polymer (ANL, 1995a). A mixture of silicates and cement can stabilize a wide range of materials including metals, oils, and solvents (ANL, 1995a). Wastes selected for solidification should be noncombustible and inorganic.

The major steps that may be used in the solidification module are shredding, solidification, and drum handling. All solid wastes must be shredded before solidification. The wastes and solidification agents are mixed together in a solidification unit and are dispersed into drums that are then capped. The filled drum undergoes a high pressure spray to remove any possible surface contamination. No other solid or liquid residual wastes are generated by this process (ANL, 1995a).

\section{A.3.10 Grouting (in-drum)}

- Submodule: $\quad \operatorname{mix}$ grout and waste in drum 
In-drum grouting is a stabilization/encapsulation process similar to solidification by which a grout binder is added to the waste. Unlike solidification, grouting is done directly in the waste container. A grouttreated drum is ready for disposal.

\section{A.3.11 General Aqueous Treatment}

- Submodule: treat aqueous waste (e.g. neutralization, filtration)

General aqueous treatment refers to a combination of processes that are used to treat relatively dilute aqueous liquid contaminants to produce a releasable treated water and solid waste residuals. These treatment technologies remove small amounts of impurities from large amounts of water and are most effective for solutions having relatively low concentrations of impurities (ANL, 1995a). Major aqueous treatment technologies include neutralization (described below), wet-air oxidation (described below), ion exchange (described below), filtration, precipitation/flocculation, evaporation (described above), and condensation. Most of these technologies are carried out in self-contained tank-like vessels that either generate chemical reactions to separate the contaminants from the water, or separate the contaminants by a physical process (such as filtration). A general aqueous treatment system, which is made up of one or more unit processes in a series, would be designed according to the site-specific feed characteristics of the waste to be treated and the discharge requirements for the site (ANL, 1995a). Illustrations of the general aqueous treatments of neutralization and filtration are shown in figures A.3-2, and an illustration of carbon adsorption is shown in figure A.1-8. 


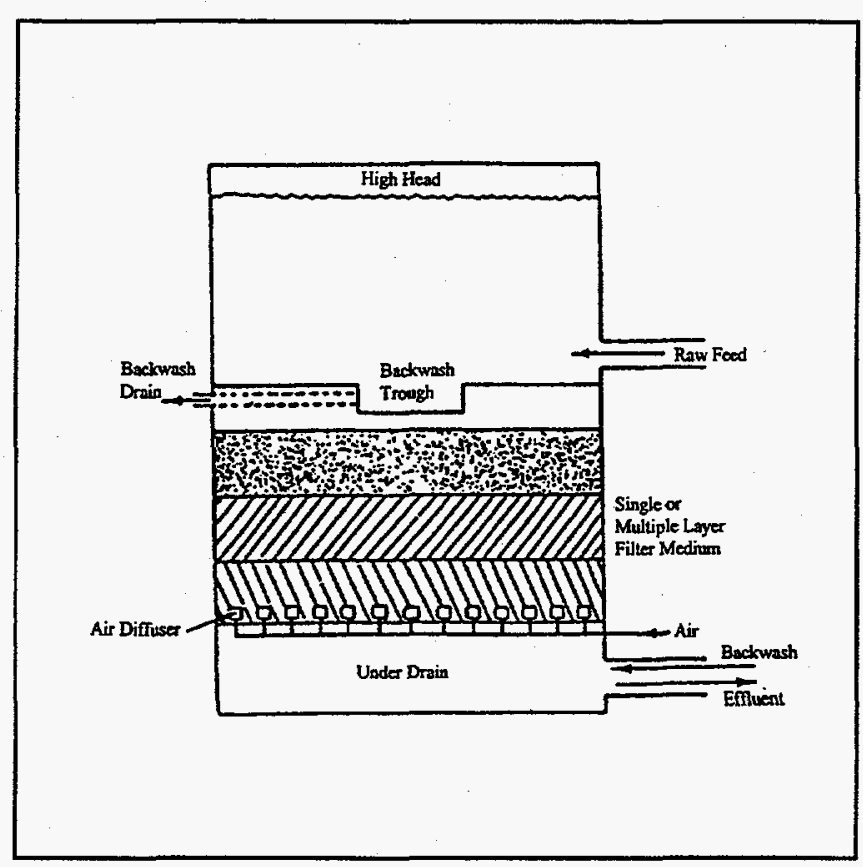

Source: ANL, 1992.

Figure A.3-2. Illustration of a Typical Filtration Tank.

\section{A.3.12 Neutralization}

- Submodule: neutralization

Neutralization is a module used to treat corrosive wastes by the addition of an acid or base to a liquid waste stream. This process alters the waste's $\mathrm{pH}$ level, and therefore, its corrosivity. This module is conducted in a tank-like configuration into which the waste is fed and mixed with an acid or base. Neutralization is usually used in conjunction with or as a submodule to other treatment modules (see A.3.11 General Aqueous Treatment).

\section{A.3.13 Ion Exchange}

- Submodule: ion exchange tank operation

Ion exchange is a process that removes nonorganic pollutants from water. An ion exchange system has a tank configuration that encloses an ion exchange column. The ion exchange column contains a charged resin. Waste solution is fed into the ion exchange column to produce a reaction. The contaminant particles 
become caught in the resin, while the purified water can be drained out of the tank (PNL, 1992). To collect the contaminant particles, an acidic or base solution is passed down through the column that bonds with the contaminants and carries them out of the column (PNL, 1992). The ion exchange column is then ready for reuse, and the contaminant solution is ready for further treatment (PNL, 1992).

\section{A.3.14 Wet-air Oxidation}

- Submodule: oxidation reactor operation

Wet-air oxidation is the destruction of organic matter in aqueous solutions under high temperatures and pressures. The reaction occurs entirely in the liquid phase as it flows through a moderate- to high-pressure vertical reactor vessel. Waste is fed into the tank-like reactor vessel (ANL, 1995b). The process begins by charging the reactor with a known mass of input waste which is then brought to operating temperature and pressure. Oxygen is then introduced to the reactor to start the oxidation reaction. A caustic is added to control the $\mathrm{pH}$ during oxidation and a catalyst is added to complete the destruction of certain organics. The process operates at $280^{\circ} \mathrm{C}$ and at a pressure of up to 1,800 pounds per square inch. The oxidation reactor is heated by a hot oil (or steam) skid. Organics are destroyed to a level such that the stabilized sludge meets land disposal restrictions established by the EPA (EG\&G, 1994).

\section{A.3.15 Vitrification}

- Submodules: vitrification

packaging/drum handling

Vitrification is the process of converting materials into a glass or glassy substance by a heat and fusion process. This process destroys organic contaminants by combustion and immobilizes inorganics by fusing them into the glass structure or by enclosing them in the product glass (ANL, 1995a). Because glass reacts nonstoichiometrically (that is, reactions do not occur in definite proportions), it can combine each atom of radioactive waste (with some exceptions) to become a part of the glass structure, thus making this technology a versatile option for most waste types (ANL, 1995a). Both liquid and solid wastes can be handled by this process. The end product is a thick, hard, and durable glass that can be readily and safely disposed.

The major steps that are considered in the vitrification module are vitrification, and drum handling. The waste is combined with into a pool of molten glass in a refractory-lined electrically heated furnace (ANL, 1995a). Any steam, gases, or entrained particulates emitted from this mixture are routed to an off-gas treatment system where particulates and volatiles are removed (ANL, 1995a). The new glass product is drained into a receiving container, or drum, which must be handled for disposal (ANL, 1995a). 
Vitrification is currently being used as a primary method for disposal of high-level waste. It can process waste forms such as brick, inorganic sludge, ash, soil, rock, concrete, and small pieces of oxidized metal (ANL, 1995a).

\section{A.3.16 Incineration}

- Submodule: incineration

Incineration is a thermal treatment of combustible wastes, using high temperatures to burn and therefore reduce the volume of a number of wastes. Although it is primarily a volume reduction technique, incineration also destroys organic chemicals present in the waste (Magleby, 1988). The end product is ash that is in an inert chemical form. Even though the radionuclide concentration in the end product is greater than the original waste, the reduced volume and inert form render a safer (if preparing for burial), more stable form of waste for disposal (ANL, 1995a). Incineration is used for combustible solid waste, inorganic and organic liquid waste, and organic sludge. This module requires the use of HEPA filters (Magleby, 1988). An off-gas treatment unit removes any radioactive particulates, and secondary liquid waste passes through a treatment system which removes any solid particles for solidification and recycles the treated waste water (ANL, 1995a).

\section{A.3.17 Metal Melting}

- Submodules: feed waste bin shredding metal melting

Metal melting is a process that can be used for the decontamination and stabilization and/or volume reduction of contaminated scrap metals. The waste is fed into an electric furnace where it is melted, and any combustible materials are destroyed. The contaminated slag is separated from the metal at the casting and cooling unit and placed into containers for disposal (EG\&G, 1992). The decontaminated metal is recovered for reuse.

The major steps used in the metal melting module are shredding and metal melting. The metal must be shredded before being fed to the furnace. The metal melting module may also emit off-gas and liquid. A liquid waste treatment unit removes dissolved and suspended solids for solidification and recycles the treated waste water for reuse (EG\&G, 1992). The off-gas system removes volatile gases and particulates (EG\&G, 1992). 
Various forms of metal, such as waste containers, failed equipment, and contaminated scrap metals can be accommodated by the metal melting module; however, the metals are assumed to be presorted before arrival at such a facility (EG\&G, 1992).

\section{A.3.18 Thermal Desorption}

- Submodules: feed waste bin

thermal desorption

Thermal desorption is the process of using ambient air, heat and/or mechanical agitation to volatilize contaminants into a gas stream for further treatment (EPA, 1993b). Wastes are fed into an oven, or kiln, that is heated to temperatures of $200-1,000^{\circ} \mathrm{F}$ to promote physical separation of the components rather than combustion (EPA, 1993b). Direct or indirect heat exchange vaporizes the volatile compounds producing an off-gas that is treated before being vented to the atmosphere (EPA, 1993b). Because thermal desorbers may operate near or above $1,000^{\circ} \mathrm{F}$, some pyrolysis and oxidation may occur in addition to the vaporization of water and organic compounds (EPA, 1993b). Collection and control equipment such as afterburners, fabric filters, activated carbon, or condensers prevent the release of the contaminants to the atmosphere (EPA, 1993b). Thermal desorption effectively treats soils, sludges and filter cakes, and removes volatile and semi-volatile organic compounds (EPA, 1993b).

\section{A.3.19 Mercury Separation}

- Submodules: mercury roasting/retorting

Mercury separation is a roasting and recovery technique (similar to thermal desorption) used to treat mercury-contaminated sludges and solids. Mercury-contaminated waste is fed into an electrically heated vacuum retort. The high oven temperatures (approximately $1000^{\circ} \mathrm{C}$ ) volatilize the moisture and mercury, breaking the physical bonds between mercury and the substance (usually soil) to which it is attached. The mercury-free items are then transferred to the solid waste treatment facility (either thermal treatment or a stabilization module) (EG\&G, 1994).

Vapors from the retort pass through a heat exchanger, which will condense the mercury while allowing the other low boiling point constituents to remain volatilized. These remaining volatilized vapors are burned in a secondary combustion chamber and the gas is sent to offgas treatment that cools and treats the gas (with various methods) to remove regulated elements and compounds before releasing the gas to the atmosphere. The discharged offgas meets given emission standards (EG\&G, 1994). 
The condensed mercury is separated from the uncondensed offgas and sent to the elemental storage bottle. The liquid mercury is then combined with copper (or zinc) powder, steel shot, and nitric acid and mixed to form a copper-mercury amalgam which is packaged for assay and inspection (EG\&G, 1994).

\section{A.3.20 Lead Recovery}

- Submodules: decontamination neutralization solidification metal melting

Lead recovery is a treatment module for solid lead waste (such as lead bricks and shielding materials or lead blankets and gloves) and lead acid batteries. Lead acid batteries are treated by neutralization and solidification (EG\&G, 1994). Lead bricks and shielding are treated by decontamination. The material arrives to the lead recovery unit by conveyor in 55-gal drums that are emptied by a hydraulic drum dumper. The waste materials are placed onto a cleaning table by means of a glove box and moved into a decontamination booth for cleaning using a liquid abrasive solution. The decontaminated materials are placed in a clean drum and taken by crane to a drum washer before exiting the building through an airlock. Contaminated secondary liquid from abrasive blasting (and battery acids) are treated in an aqueous waste treatment unit, and filters used in the blasting operation are changed monthly and placed in drums for disposal. Material such as lead blankets, lead shot and leaded gloves are treated in a lead melter. These materials are dumped into a shredder and combined with sodium carbonate to form a lead paste that is collected under the shredder and dumped into a stirrer and then a melter. The lead is melted in an induction melting furnace that separates the radioactive slag from the lead, and any emissions are collected and treated in an offgas treatment facility (EG\&G, 1994).

\section{A.3.21 Packaging}

- Submodule: place waste in drum or cask

Packaging, the process by which waste is contained, is the module that usually occurs after waste has been treated or before offsite shipment. Wastes can be packaged in a variety of containers, and package designs are selected on the basis of the form and type of waste produced (ANL, 1995a). Some common container types include 55-gal drums and concrete casks (ANL, 1995a). Packaging occurs indoors and with varying levels of shielding, depending on the form and level of waste being handled. A small amount of dust emissions may occur. 


\section{A.3.22 Reactive Metals Recovery}

\section{- Submodule: deactivation}

Deactivation is a method of stabilizing reactive contaminants prior to disposal. Reactives, such as sodium, uranium metal, or cyanides, are materials that are extremely volatile. Through the application of different chemicals, reactives can be transformed by chemical reaction to a more stable form. Metallic sodium waste is sent to the sodium destruction area and placed in the sodium reactor, where it reacts with water and is neutralized by adding acid, and sent to the aqueous waste module (EG\&G, 1994). Metallic uranium waste is sent to the uranium removal area and placed in a reactor where it is dissolved with nitric acid. Resultant uranium liquids can be reacted with a lime solution that precipitates most of the metal as a hydroxide sludge that can either pass through a pressure filter or be chemically treated for additional processing in the precipitation unit. Any additional liquid uranium waste may undergo further treatment through a general aqueous module and ion exchange. Likewise, liquid toxic metal waste is chemically treated with hydrogen peroxide and sodium hypochlorite to oxidize the metal, and treated with ferric sulfate lime and a polymer to coprecipitate metal in a hydroxide floc, or sludge. The floc settles in a clarifier which is part of the same unit and is processed by a filter press in a solids removal area, and clarifier liquid is filtered in a pressure filter to remove fine particles before proceeding to the ion-exchange system to remove traces of dissolved metal. Treated water can often be either recycled for reuse or discharged (EG\&G, 1994).

\section{A.3.23 Soil Washing}

- Submodule: separate, scrub, and wash soil

The soils washing module is a flameless organic removal unit that collects and treats soils contaminated with organic residues (EG\&G, 1994). The process consists of a material size separation and washing system, an oil/water/solids separator, a soils washing system, and ancillary support systems. Standard sized material is introduced into a primary washing trommel, which is a tank-like configuration. Oversized material is washed in a secondary washing trommel, while undersized material is pumped to an oil/water/solids separator. The oil/water/solids separator collects surface oil from the waste water, and then pumps the remaining waste water through bag filters and ion exchange units to collect any remaining oils, which are collectively sent to the organic destruction portion of the aqueous waste treatment module. Finally, the solids are allowed to settle and are pumped into the soils washing system that scrubs, rinses, dilutes with clean water, and filters the soils that are then sent to the stabilization module (EG\&G, 1994). 


\section{A.3.24 Debris Washing}

- Submodule: spray, wash, and rinse debris

Debris washing is a flameless unit that collects and treats oversized material contaminated with organic residues utilizing a feed preparation unit (shredder), a surfactant spray and washing system, an oil/water/solids separator, and ancillary support systems (EG\&G, 1994). The debris, which is usually cemented solids, is reduced in size in the feed preparation unit and is transported by conveyor to the surfactant spray and washing system. In the wash system, the waste passes through two tank-like configurations containing high pressure water/surfactant sprays where the debris is "washed," and then it passes to a third tank where it is rinsed with clean water. Oil collected from the surface of the waste water is drawn off and pumped through bag filters and ion exchange units, and is then sent to the organics destruction portion of the aqueous treatment module. Inclined plates in the retention tank allow the solids to settle to the bottom where a low-velocity drag conveyor removes the material. The solids are then pumped into the secondary high-pressure spray tank for surfactant washing and are subsequently sent to stabilization (EG\&G, 1994).

\section{A.3.25 Sludge Washing}

- Submodule: collect and treat sludge

The sludge washing module collects and treats sludges contaminated with organic residues through the use of liquid carbon dioxide as a solvent. Contaminated sludge is temporarily stored in tanks from which the sludge is screened, released into a feed hopper, and pumped into a solvent extraction system (EG\&G, 1994). The extraction/gravity settling system consists of one or more agitation extraction vessels where contaminated sludge is mixed with the liquid carbon dioxide. The mixture is agitated and gravity separation of the waste material and carbon dioxide is allowed to occur at intervals. The solvent/organic phase is drained to a solvent recovery system, where the carbon dioxide is recovered in a vapor recompression cycle for reuse in the solvent extraction system, and recovered oil is sent to organics storage for further treatment. Once the extraction is complete, water is injected into the extraction vessel to displace and remove any residual carbon dioxide, and the remaining sludge is fed to a filtration system from which it is eventually suitable for land disposal (EG\&G, 1994).

\section{A.3.26 Polymer Stabilization}

- Submodule: polymer stabilization 
Polymer stabilization is a treatment module in which solids and slurries discharged from other treatment modules in a facility are encapsulated. Input waste to this module includes inorganic debris, spent filters, spent carbon, spent resins, incinerator ash, sludges, and concentrator bottoms (EG\&G, 1994). The input is sent to a preparation and feed unit operation, after which it goes to a dryer. The dried waste and polymer agent are dispensed into drums, mixed in a blender operation and transferred to the encapsulation unit operation. The encapsulation unit operation consists of an extruder that melts and pushes the waste and polymer matrix into 55-gallon drums that, once filled, are transferred to an enclosure where cooling is achieved by forced air ventilation (EG\&G, 1994). After cooling, the drum is capped and washed, ready for final disposal.

\section{A.3.27 Interim Storage}

- Submodules: drum/cask placement drum/cask retrieval

Interim storage is a module that can be found at each WM facility and may be used at several points within a treatment train (front-end operations, between modules, before shipping). Wastes arriving from assay/inspection are stored at a specific location or storage cell.

Some features common to storage areas include spill collection, a combination of sloping floors and sumps, concrete floor dividers, and gamma and alpha radiation control monitors (EG\&G, 1992). All storage facilities are located indoors to control any potential emissions or spills. Submodules associated with interim storage are drum/cask placement and drum/cask retrieval. These activities require the use of a forklift or crane.

\section{A.3.28 Certification/shipping}

- Submodules: assay/RTR

load drum/cask

The certification/shipping module receives containers, usually of treated wastes, and prepares them for shipment. The certification/shipping facility occurs on the back end of a treatment train. It is during this module that all outgoing waste is inspected to insure compliance with transportation, storage, and disposal regulations and requirements (EG\&G, 1992).

Packaged waste containers arrive from treatment facilities via conveyors, carts, or other transport devices. Containers are removed from the transport devices and placed in a staging area. The containers are then visually examined, tagged, logged, recorded, and sent to an assay/certification unit operation. In this unit 
operation, the containers are examined by radioassay devices to allow both alpha and gamma radioactivity classification in accordance with the appropriate transportation, storage, and disposal criteria (EG\&G, 1992).

The containers are then weighed and measured to determine waste density (EG\&G, 1992). Ultrasonic instruments or an RTR device determines the existence of materials restricted from transportation, storage, and disposal. Following examination, each container is labeled and its properties are logged and recorded into a computerized database. The containers are then moved to a temporary storage area until they are ready for shipment to an interim storage or disposal facility. Shield overpacks are used for those containers that do not meet the transportation dose criteria. Containers may be loaded on a flat-bed trailer or van trucks (EG\&G, 1992). It is assumed that all of these operations occur indoors.

\section{A.3.29 Front End Disposal}

- Submodules: inspection and assay

Front end disposal is a conjunction module used between the back-end treatment or storage modules and a disposal module. Upon arrival via a transport vehicle, waste containers are unloaded by forklift or overhead bridge crane, and are placed in a staging area where the containers are visually examined, labeled, logged, and sent to inspection and assay (EG\&G, 1994). At the inspection and assay unit, the category of the received waste is verified against the results obtained from the back-end treatment or storage modules, and the containers are afterwards sent to the disposal module (EG\&G, 1994).

\section{A.3.30 Shallow Land Burial}

- Submodules: drum handling

drum disposal

Shallow land burial is a disposal module that consists of placing waste containers in an excavated trench, backfilling voids between containers with sand or other earthen material, compacting the backfill material, and covering the waste with a cap of earthen material or cover system (ANL, 1995a). The cap is multilayered and serves as a low permeability barrier to restrict the infiltration of water into the disposal trenches. The cap also restricts human, plant, and animal intrusion into the waste, while reducing gamma exposure rates at the surface to an acceptable level (EG\&G, 1987a).

The disposal components of a shallow land burial facility consist of the waste trench, trench drainage system, monitoring system, backfill, cover, and any other engineered features required for successful operation (Cannon et al., 1986). Forklifts and/or cranes are used to unload and place waste containers in 
the trench, the size of which is site-specific. The backfill used, such as chemical or suspension grouts, quickly encapsulates the waste, and the multi-layered trench cover designs are site-specific.

\section{A.3.31 Tumulus Disposal}

- Submodules: tumulus vault loading tumulus vault emplacement

Tumulus disposal is a disposal module that involves above-grade disposal of waste in concrete vaults. Once a vault is filled with waste containers, it is backfilled and sealed with concrete. A vault is then placed on a concrete pad; more than one vault can occupy a pad, and vaults can be stacked. Cranes are used to load the tumulus vault and then to place the vault on the concrete pad (Styers, 1989). After final placement, the vaults are covered with a multi-layered earthen mound. The above grade construction with concrete pad and earthen mound help prevent erosion and leaching.

\section{A.3.32 Belowground Vault Disposal}

- Submodules: drum handling

vault closure

Belowground vault disposal is a disposal module that consists of placing waste in engineered concrete structures located below natural grade (EG\&G, 1987a). The structure is divided into several sections and cells and is constructed of reinforced concrete floors and walls. Cranes are used to unload trucks and place waste containers in the vault. Liquid waste can be combined with dry solids to form a cementitious slurry or grout. The grout may then be pumped into a belowground vault, and it is assumed that no discharges would occur during grout transfer under normal operating conditions. The vault is backfilled with sand (or sometimes a sandy gravel), which serves as a base for the construction of a concrete roof to seal the vault. The sealed vault is then covered by a multi-layer earthen mound to restrict water infiltration and any other possible intrusion.

\section{A.4 Modeling Parameters ANd Assumptions}

For the WM PEIS comparative analyses of waste consolidation alternatives, comparable exposure data were needed for each relevant DOE installation, each type of facility and worker activity, and for installation- or site-specific contaminant inventories and concentrations. To meet this requirement, it was necessary to use dose assessment models to estimate worker exposure data of consistent quality that would allow meaningful comparison of WM alternatives. These exposure estimates were based on generic WM 
facility modules and on simplified but consistent assumptions about worker activities, worker protection, and exposure scenarios throughout the analyses. Table A.4-1 presents modeling parameters for the WM modules.

As stated previously, for worker radiation exposure modeling, only the main worker activities or treatment operations were considered to represent each module. In order to estimate external radiation exposure rates to workers involved in various processes, information regarding source geometries, dimensions, and characteristics was necessary. In table A.4-1, geometry refers to the shape of the source to which the worker is exposed (e.g., cylindrical tank, rectangular shredder, etc.); general dimensions and characteristics of the source are also presented. These variables are required along with shielding information and source-to-receptor distances discussed in section A.2 as input to dose assessment models. 
Waste Management PEIS Methodology for Estimating Human Health Risks

Table A.4-1. WM Module Modeling Parameters

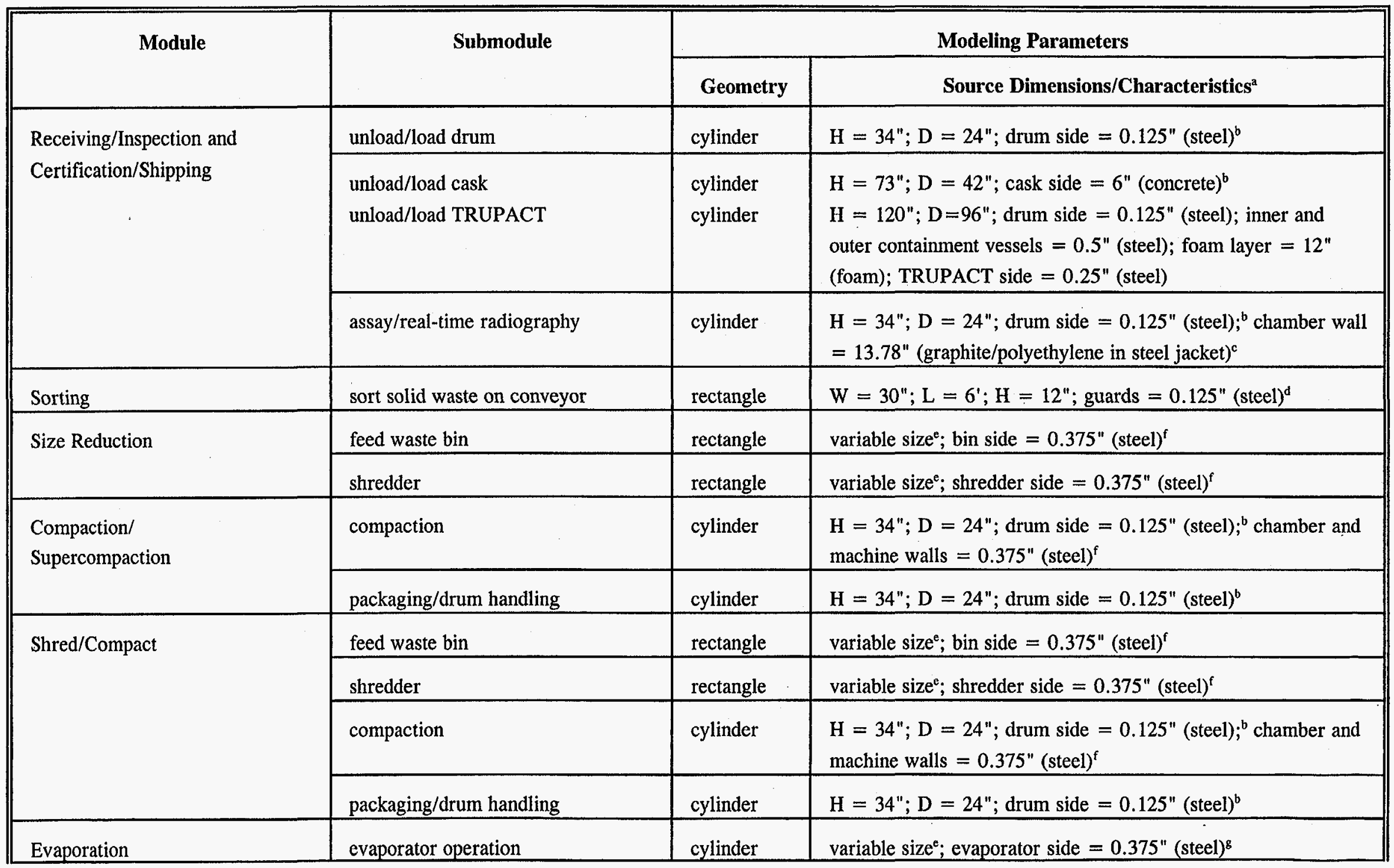


Waste Management PEIS Methodology for Estimating Human Health Risks

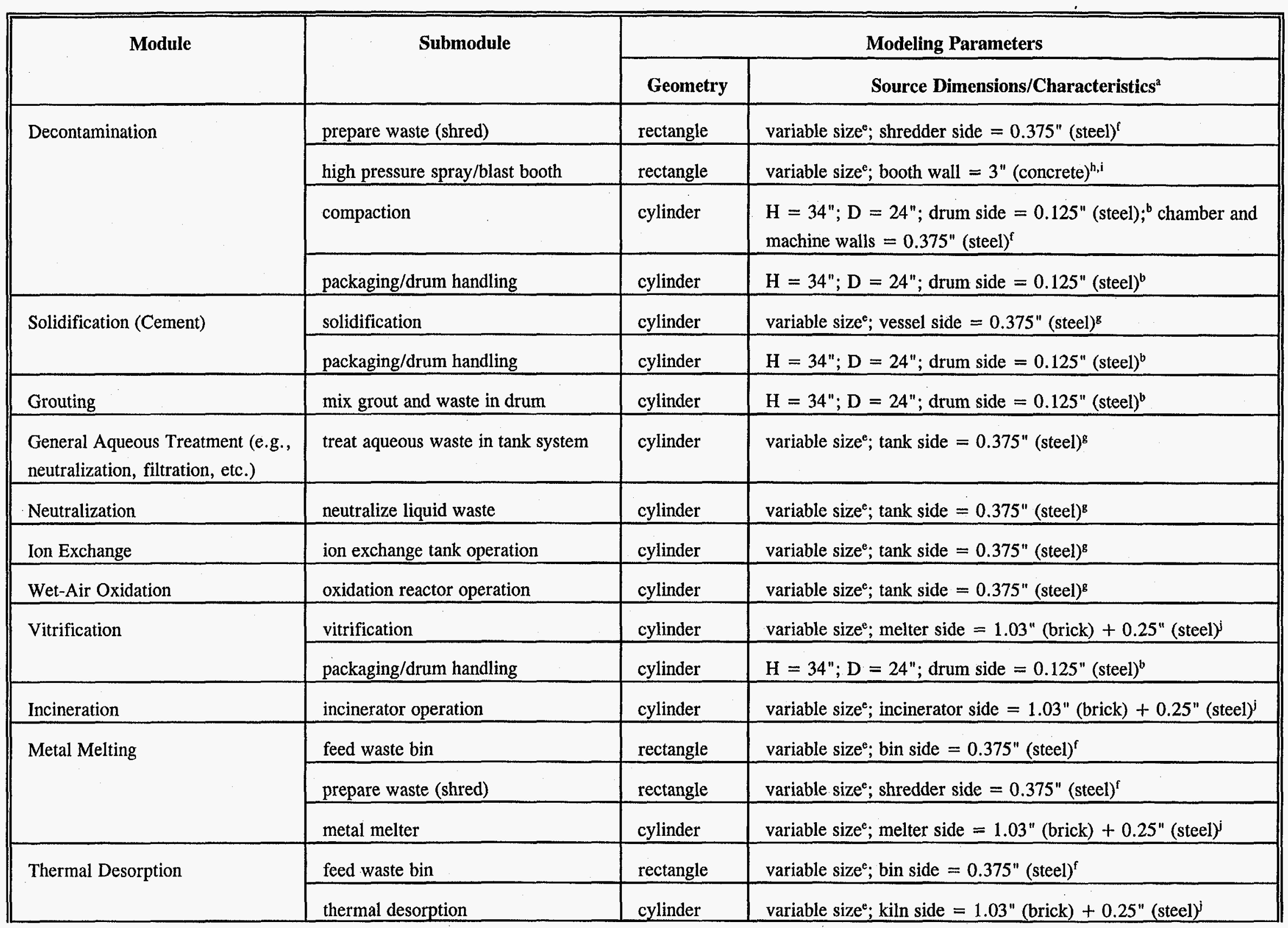


Waste Management PEIS Methodology for Estimating Human Health Risks

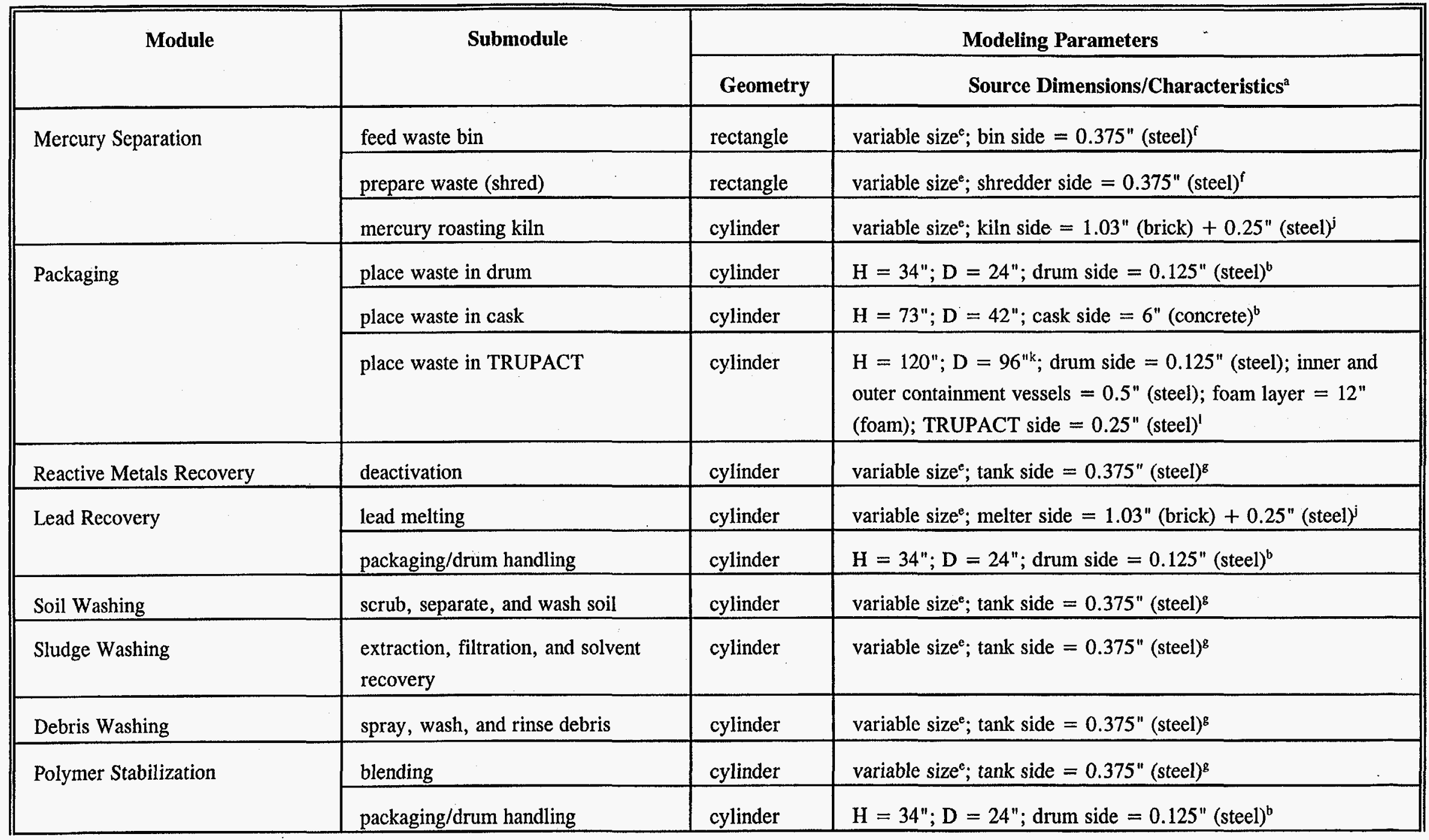


Waste Management PEIS Methodology for Estimating Human Health Risks

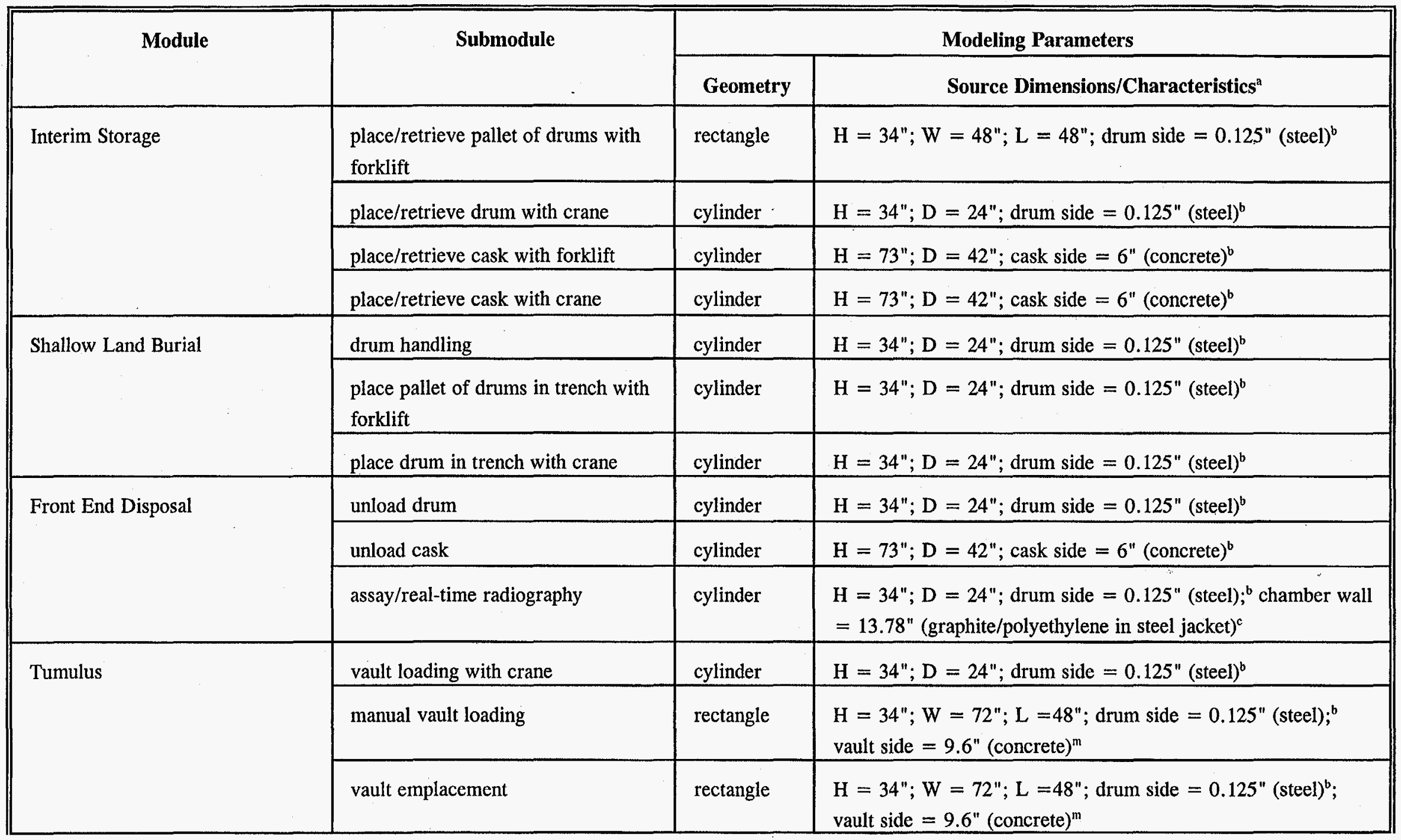


Waste Management PEIS Methodology for Estimating Human Health Risks

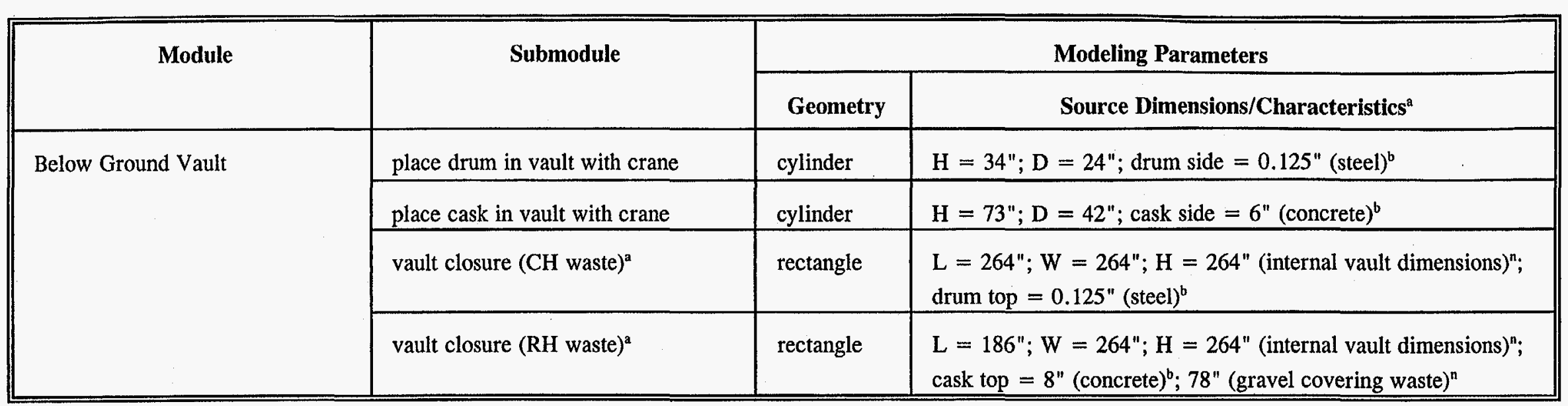

${ }^{2} \mathrm{H}=$ height; $\mathrm{D}=$ diameter; $\mathrm{L}=$ length; $\mathrm{W}=$ width. Measurements given for vessel sides and walls are thicknesses. $\mathrm{CH}=$ contact-handled; $\mathrm{RH}=$ remote- handled.

b Stewart et al., 1989.

c Pound, 1991.

d EG\&G, 1987b (shredder compactor).

e Treatment vessels that vary in size with throughput rates are assumed to have a one cubic meter capacity for dose rate modeling; dose rates are then adjusted to reflect estimated vessel sizes. Vessel sides are assumed to be equal in length (rectangle $\mathrm{H}=\mathrm{W}=\mathrm{L}$; cylinder $\mathrm{H}=\mathrm{D}$ ).

f LLNL, 1992.

g Neilsen, 1992.

h EG\&G, 1987b (decontamination).

I Walker, C., Ready Mix Concrete Co., personal communication with Jim Hutchison, ORNL Center for Risk Management, 1993.

i Nail, T., Southdown Environment Co., personal communication with Jim Hutchison, ORNL Center for Risk Management, 1993.

k Wu et al., 1993.

1 DOE, 1990.

m Styers, 1989.

n EG\&G, 1987a. 


\section{REFERENCES}

ANL. See Argonne National Laboratory.

Argonne National Laboratory. 1992. Generic Environmental Impacts of Environmental Technologies

(Draft). December 1992. Argonne, Ill.: Argonne National Laboratory.

Argonne National Laboratory. 1993. PEIS Technology Catalog. Argonne, Ill.: Argonne National Laboratory.

Argonne National Laboratory (ANL). 1995a. Low-Level Waste Inventory, Characteristics, Generation, and Facility Assessment for Treatment, Storage, and Disposal Alternatives Considered in the U.S. Department of Energy Waste Management Programmatic Environmental Impact Statement, ANL/EAD/TM-20 (Draft). M.L. Goyette. Argonne, Ill.: Argonne National Laboratory.

Argonne National Laboratory. 1995b. Low-level Mixed Waste Inventory, Characteristics, Generation, and Facility Assessment for Treatment, Storage, and Disposal Alternatives Considered in the U.S. Department of Energy Waste Management Programmatic Environmental Impact Statement. ANL/EAD/TM-32 (Draft). B.D. Wilkins, Y.Y. Wang, D.A. Dolak, and N.K. Meshkov. Argonne, Ill.: Argonne National Laboratory.

Battelle Pacific Northwest Laboratory (PNL). 1992. ER Treatment and Technology Catalog and Database. DE-AC06-76RLO 1830. Hanford, Wash.: Battelle Pacific Northwest Laboratory.

Bloom, S. 1993. Models for Close-in Atmospheric Dispersion, Explosive Releases, and Particle Deposition. ORNL/TM-12452. Oak Ridge, Tenn.: Oak Ridge National Laboratory. October 1993.

Cannon, J.B., et al. 1986. Shallow Land Burial of Low-Level Radioactive Waste. ORNL/TM-9496. Oak Ridge, Tenn.: Oak Ridge National Laboratory. 1986.

DOE. See U.S. Department of Energy.

EG\&G. See EG\&G Idaho, Inc.

EPA. See U.S. Environmental Protection Agency.

EG\&G Idaho, Inc. 1987a. Conceptual Design Report Alternative Concepts for Low-Level Radioactive Waste Disposal. DOE/LLW-60T. Idaho Falls, Id.: EG\&G Idaho, Inc. June 1987. 
EG\&G Idaho, Inc. 1987b. "Documentation of Currently Operating Low-Level Radioactive Waste Treatment Systems," in Shredder/Compactor Report and the Component Decontamination Shop at the Oskarshamn Nuclear Power Plant. DOE/ID-12568. Idaho Falls, Id.: EG\&G Idaho, Inc.

EG\&G Idaho, Inc. 1992. Waste Management Facilities Cost Information Report. EGG-WTD-10443. Idaho Falls, Id.: EG\&G Idaho, Inc. October 1992.

EG\&G Idaho, Inc. (EG\&G). 1993. Waste Management Facilities Cost Information Report for Greater-Than-Class C and DOE Equivalent Special Case Waste. EGG-WM-10701. Idaho Falls, Id.: EG\&G Idaho, Inc. July 1993.

EG\&G Idaho, Inc. 1994. Interim Report: Waste Management Facilities Cost Information for Mixed LowLevel Waste. EGG-WM-10962. Idaho Falls, Id.: EG\&G Idaho, Inc. March 1994.

Grove Engineering, Inc. 1992. MicroShield Version 4 User's Manual. Rockville, Md.: Grove Engineering, Inc.

Hartmann, H.M., A.J. Policastro, and M.A. Lazaro. 1994. "Hazardous Waste Transportation Risk Assessment for the U.S. Department of Energy Environmental Restoration Risk Assessment for the U.S. Department of Energy Environmental Restoration and Waste Management Programmatic Environmental Impact Statement." Paper presented at Waste Management '94 Conference, February 27-March 3, at Tucson, AZ.

ICRP. See International Commission on Radiological Protection.

International Commission on Radiological Protection (ICRP). 1990. Recommendations of the International Commission on Radiological Protection. ICRP Pub. 60. New York: Pergammon Press.

Jayjock, M.A. 1988. "Assessment of Inhalation Exposure Potential from Vapors in the Workplace." $A m$. Ind. Hyg. Assoc. J. 49(8): 380-385.

Jayjock, M.A. 1993. "Back Pressure Modeling of Indoor Air Concentrations from Volatilizing Sources." Am. Ind. Hyg. Assoc. J., accepted for publication.

LLNL. See Lawrence Livermore National Laboratory.

Lawrence Livermore National Laboratory (LLNL). 1986. A Guide to Radiological Accident Considerations for Siting and Design of DOE Nonreactor Nuclear Facilities. LA-10294-MS. Livermore, Cal.: Lawrence Livermore National Laboratory. 
Lawrence Livermore National Laboratory. 1992. Cost-Benefit Analysis for Waste Compaction Alternatives at Lawrence Livermore National Laboratory, Addendum $A$ to the Waste Minimization and Pollution Prevention Awareness Plan of May 31, 1991. UCRL-21215-91-Add A. Livermore, Cal.: Lawrence Livermore National Laboratory. January 1992.

MMES. See Martin Marietta Energy Systems.

Magleby, M. 1988. Low Level Radioactive Waste Volume Reduction and Stabilization Technologies Resource Manual. DOE/LLW-76T. Prepared by Ebasco Services, Inc. for EG\&G Idaho, Inc. December 1988.

Martin Marietta Energy System (MMES). 1992. Hazard Screening Application Guide, Safety Analysis Report Update Program. ES/CSET-2/R1. Oak Ridge, Tenn.: Martin Marietta Energy Systems. June 1992.

Morrison-Knudsen Corporation. 1993. Fax from Morrison-Knudsen to J. Legg, ORNL. MKES Doc. No. WMF6-L-S-07-152.

Neilsen, E. 1992. Miscellaneous Underground Radioactive Waste Tanks. WHC-EP-0560. Richland, Wash.: Westinghouse Hanford Co.

ORNL. See Oak Ridge National Laboratory.

Oak Ridge National Laboratory (ORNL). 1995a. DOE Public and Onsite Population Health Risk Evaluation Methodology for Assessing Risks Associated with Environmental Restoration and Waste Management. ORNL-6832. Oak Ridge, Tenn.: ORNL Center for Risk Management. April 1995.

Oak Ridge National Laboratory. 1995b. DOE Worker Health Risk Evaluation Methodology for Assessing Risks Associated with Environmental Restoration and Waste Management. ORNL-6833. Oak Ridge, Tenn.: ORNL Center for Risk Management. June 1995.

PNL. See Battelle Pacific Northwest Laboratory.

Pound, D. 1991. Technologies for Sorting, Assaying, Classifying and Certifying TRUW within the U.S. EGG-M-90207. Idaho Falls, Id.: EG\&G Idaho, Inc.

Shropshire, D. 1993. Process Functional Diagrams and Mass Balance Calculations for the Integrated MLLW Treatment Facility. DES-56-93. Data Package. December 1993. 
Stewart, R.C., et al. 1989. Remote-Handled TRUW Solid Waste Characterization Study. ORNL/TM11050. Oak Ridge, Tenn.: Oak Ridge National Laboratory.

Styers, D.R. 1989. Tumulus Disposal Demonstration Project Assessment Plan for Potential Worker Exposure. ORNL/Sub/89-21242/1. Rev. 1. Oak Ridge, Tenn.: Oak Ridge National Laboratory. March 1989.

Trigilio, G. 1981. Volume Reduction Techniques in Low-Level Radioactive Waste Management. DOE/ET0028 . May 1981.

U. S. Environmental Protection Agency. 1988. Protocols for Generating Unit-Specific Emission Estimates of Equipment Leaks of VOC and VHAP. OAQPS. EPA-450/3-88-010. October 1988.

U. S. Environmental Protection Agency. 1989. Estimation of Air Emissions from Cleanup Activities at Superfund Sites. Vol.3, Air/Superfund National Technical Guidance Study Series, PB89-180061.

U. S. Environmental Protection Agency. 1991. Chemical Engineering Branch Manual for the Preparation of Engineering Assessments. Washington, D.C.: Office of Toxic Substances.

U. S. Environmental Protection Agency (EPA). Office of Air Quality. 1993b. Air/Superfund National Technical Guidance Study Series: Models for Estimating Air Emission Rates from Superfund Remedial Actions. EPA-451/R-93-001. March 1993.

U. S. Environmental Protection Agency. 1993a. External Exposure to Radionuclides in Air, Water, and Soil. Federal Guidance Report Number 12. EPA 402-R-93-081. Washington, D.C. : Office of Radiation and Indoor Air.

U.S. Department of Energy (DOE). 1990. Final Safety Analysis Report for the Waste Isolation Pilot Plant. WP 02-9. Carlsbad, N.M. May 1990.

U.S. Department of Energy. 1991. Integrated Data Base for 1991: US Spent Fuel and Radioactive Waste Inventories, Projections, and Characteristics. DOE/RW-0006. Rev. 7. October 1991.

U.S. Department of Energy. 1992. US DOE Radiological Control Manual. DOE/EH-0256T. June 1992.

U.S. Department of Energy. 1993. US DOE Interim Mixed Waste Inventory Report: Waste Streams, Treatment Capacities, and Technologies, Vol. 1. DOE/NBM-1100. April 1993. 
Wagner, K., et al. 1987. Drum Handling Manual for Hazardous Waste Sites. Pollution Technology Review No. 143. Park Ridge, N.J.: Noyes Data Corp.

Wu C.F., et al. 1993. WIPP Waste Acceptance Criteria and Transportation System. Conf-911268-3. July 1993. 
Distribution:

DOE Reading Room

1301 Clay Street

Oakland, CA 94612

The State (DTSC) Library

Lincoln Plaza Building

4th and $P$ Street

Sacramento, CA 92410

Lawrence Livermore Eastgate Visitor

Center

Greenville Road

Livermore, CA 94550

Simi Valley Public Library

Tapo Canyon Road

Ventura, CA 93001

The State (DTSC) Library

State of California

P.O. Box 806

Sacramento, CA 95812-0806

Davis Public Library

14th Street

Davis, CA 95617

Berkley Public Library

Kittredge and Shattuck

Berkley, CA 94794

MINSY Public Affairs Office Code

1160-Building 47

Vallejo, CA 94592-5100

SNL/CA Public Reading Room

7011 East Avenue

Building 901

Livermore, CA

Government Reference Center

Mesa County Public Library

530 Grand Avenue

Grand Junction, CO 81501
Technical Resource Center

Grand Junction Project Office

2597 B 3/4 Road

Grand Junction, CO 81503

Rocky Flats Environmental Technology Site

Reading Room

Front Range Community College Library

3645 West 112th Avenue

Westminster, CO 80030

U.S. EPA Region VIII

Attn: Michelle Bontrager

999 18th Street, Suite 500

Denver, CO 80202-2405

Colorado Department of Health

Attn: Dan Scheppers

4300 Cherry Creek Drive South

Denver, CO 80222-2405

Rocky Flats Citizens Advisory Board

Attn: Ken Korkia

9035 Wadsworth Parkway, Suite 2250

Westminster, CO 80021

Standley Lake Library

Attn: Kathy Hollaran

8485 Kipling Street

Arvada, CO 80005

Windsor Public Library

Attn: Mary Ellen Johnson

323 Broad Street

Windsor, CT 06095

Jacksonville Public Library

Documents Department

122 North Ocean Street

Jacksonville, FL 32202

Information Repository Center

Largo Public Library

351 East Bay Drive

Largo, FL 34640 
Martin Marietta Specialty Components Community Relations Center 7381 114th Avenue, North, Suite 403A Largo, FL 34643

Pinellas Park Public Library

7770 52nd Street, North

Pinellas, FL 34665

Atlanta Public Library

Government Documents Section

Attn: Gene Hughs

1 Margaret Mitchell Square

Atlanta, GA 30303

Chatham County Public Library

2002 Bull Street

Savannah, GA 31401

Reese Library

Attn: Elfriede McLean-Document Center

Augusta College

2500 Walton Way

Augusta, GA 30904-2200

Pearl Harbor Naval Base Library

Code 90L

1614 Makalapa Drive

Pearl Harbor, HI 96860-5350

Aiea Public Library

99-143 Monanalua Road

Aiea, HI 96701

Hawaii State Library

478 South King Street

Honolulu, HI 96813

Pearl City Public Library

1138 Waimano Home Road

Pearl City, HI 96782
Boise Public Library

Attn: Julie Davis

Government Documents Section

715 S. Capitol Boulevard

Boise, ID 83702

City of Burley Public Library

Attn: Mona Kenner

1300 Miller Avenue

Burley, ID 83702

Clearwater Memorial Library

Attn: Jill Lynch

402 Michigan Avenue

P.O. Box 471

Orofina, ID 83544

INEL Oversight Program Library Department of Health \& Welfare Attn: Nancy Quirk 1410 North Hilton, 3rd Floor

Boise, ID 83706

INEL Technical Library

1776 Science Center Drive

P.O. Box 1625

Idaho, ID 83415-2300

Idaho Falls Public Library

Attn: Ginny Atwood

457 Broadway

Idaho Falls, ID 83402

State Library

Attn: Stephanie Kirkay

325 West State Street

Boise, ID 83702

Library \& Archives State Historical Society Attn: William E. Tydeman, Archivist 450 North Fourth Street Boise, ID 83209 
State University Library

Documents Department

Attn: Larry Murdock

P.O. Box 8089

Pocatello, ID 83209

Pocatello Public Library

Attn: Gaila Clough

113 S. Garfield

Pocatello, ID 83204

Shoshone-Bannock Library

Attn: Ardith Peyope

Bannock \& Pima Streets

HRDC Building

Fort Hall, ID 83203

Twin Falls Public Library

Attn: Linda Parkinson

434 Second Street, East

Twin Falls, ID 83301

Consolidated Free Library

Attn: Lee Starr

Hayden Branch

8385 North Government Way

Hayden Lake, ID 83835

City of Emmett Public Library

Attn: Marsha Werle

275 South Hayes

Emmett, ID 83617

Lemont Public Library

Attn: Jackie

810 Porter Street

Lemont, IL 60439

U.S. DOE Public Document Room

Document Dept., University Library

3rd Floor Center

University of Illinois at Chicago

801 S. Morgan Street

Chicago, IL 60607
Bedford Park Public Library

Attn: Head Librarian

7816 West 65th Place

Bedford Park, IL 60510

Bridgeview Public Library

Attn: Head Librarian

7840 West 79th Street

Bridgeview, IL 60455

Ames Lab

111 T.A.S.F.

Attn: Steve Karsjen

Ames, IA 50011

Ames Public Library

515 Douglas Avenue

Ames, IA 55001

Environmental Information Center

175 Freedom Boulevard

Kevil, KY 40253

Rice Public Library

8 Wentworth Avenue

Kittery, ME 03904

Red Bridge Branch

Mid-Continent Library

11140 Locust Street

Kansas City, MO 64108

Columbia Public Library

Attn: Marilyn McCleod

100 West Broadway

Columbia, MO 65203

Carson City Public Library

Attn: Wendell Huffman

900 North Roop Street

Carson City, NV 89701 
Nevada Test Site Reading Room Coordination \& Information Center Attn: Cinde Ashley 3084 South Highland Drive Las Vegas, NV 89109

Nevada State Library Attn: Patricia Deadder Capitol Complex

Carson City, NV 89710

Portsmouth Public Library

8 Islington Street

Portsmouth, NH 03601

Maywood DOE Public Info Center

43 West Pleasant Avenue

Maywood, NJ 07607

Middlesex County Library

Plainsboro Branch

P.O. Box 278

Plainsboro, NJ 08536

National Atomic Museum

Kirkland Air Force Base

20358 Wyoming Boulevard, South

Albuquerque, NM 87116

Albuquerque Technical Vocational Institute

Main Campus Library

525 Buena Vista Drive, SE

Albuquerque, NM 87116

Museum Park Complex

15 th \& Central

Suite 101

Los Alamos, NM

Longwood Public Library

800 Niddle County Road

Middle Island, NY 11953

EPA Records Center

290 Broadway

New York, NY 10007-1866
Records Center

26 Federal Plaza

29th Floor, Room 2900

New York, NY 10278

Mastics-Moriches-Shirley

Community Library

425 William Floyd Parkway

Shirley, NY 11967

Brookhaven National Laboratory

Research Library Building 477A

Upton, NY 11973

Colonie Library

629 Albany-Shaker Road

Loudenville, NY 12211

Saratoga Springs Library

Attn: Claudia Hayes

320 Broadway

Saratoga Spring, NY 12866

Schenectady Public Library

Attn: Tim McGowan

Main Branch

99 Clinton Street

Schenectady, NY 12305-2083

Jennifer Nelson, Public Affairs

MS-Trailer A

10282 Rock Springs Road

West Valley, NY 14171

Town of Concord Library

23 North Buffalo Street

Springville, NY 14141

Buffalo \& Erie Bounty Public Library

Science \& Technology Department

Lafayette Square

Buffalo, NY 14203 
Olean Public Library

Attn: Lance Chaffee

134 N. 2nd Street

Olean, NY 14760

Brunswick County Government Center Attn: Andrea Merklinger 45 Court House Drive, N.E.

Bolivia, NC 28422

New Hanover County Public Library

Attn: Daniel Horn

201 Chestnut Street

Wilmington, NC 28401

Columbus Metropolitan Library

Main Branch

96 S. Grant Avenue

Columbus, $\mathrm{OH} 43215$

Northside Branch Library

1423 N. High Street

Columbus, $\mathrm{OH} 43215$

State Library of Ohio

Attn: Clyde Hordusky

$65 \mathrm{~S}$. Front Street

Columbus, $\mathrm{OH} 43215$

West Jefferson Public Library

Attn: Sharon Shrum

270 Lilly Chapel Road

West Jefferson, OH 43162

Kent State University

Ashtabula Campus Library

3431 W. 13th Street

Ashtabula, $\mathrm{OH} 44004$

Public Environmental Information Center

10845 Hamilton Cleves Highway

Harrison, $\mathrm{OH} 45030$
Miamisburg Senior Adult Center

Public Reading Room

305 Central Avenue

Miamisburg, $\mathrm{OH} 45343$

DOE Environmental Information Center

505 West Emmitt Avenue

Suite 3

Waverly, $\mathrm{OH} 45690$

Portland State University

Branford Price Millar Library

Attn: Michael Bowman

SW Harrison and Park

Portland, OR 97202

Carnegie Library

Attn: James Bobick

Science and Technology Department

4400 Forbes Avenue

Pittsburgh, PA 15213

Charleston County Library

Attn: Nancy Woodward

404 King Street

Charleston, SC 29403

DOE/SRS Public Reading Room

Savannah River Operations Office

Attn: Becky Craft

P.O. Box A

Aiken, SC 29802

South Carolina State Library

Attn: Mary Bostick

1500 Senate Street

Columbia, SC 29201

Gregg-Graniteville Library

University of South Carolina-Aiken

Attn: Allison Johnson

171 University Parkway

Aiken, SC 29801 
DOE Environmental Information Resource Center (IRC)

105 Broadway

Oak Ridge, TN 37830

Clinton Public Library

Attn: Jane Giles

118 South Hicks Street

Clinton, TN 37716

DOE Public Reading Room

Oak Ridge Operations Office

Attn: Amy Rothrock, Room 112B

55 Jefferson Circle

Oak Ridge, TN 37831

Lawson McGhee Public Library

Attn: Nelda Hill

500 West Church Avenue

Knoxville, TN 37902

Oak Ridge Public Library

Civic Center

1401 Oak Ridge Turnpike

Oak Ridge, TN 37830

Memphis/Shelby County Public Library and Information Center

Attn: Government Publications Dept.

1850 Peabody Avenue

Memphis, TN 38104

Oliver Springs Public Library

Attn: Jennifer Newcome

607 Easterbrook Avenue

Oliver Springs, TN 37840

Rockwood Public Library

Attn: Margaret Marrs

117 North Front Avenue

Rockwood, TN 37854
Amarillo College Library

Attn: Karen McIntosh

Lynn Library, DOE Reading Room

2201 S. Washington

Amarillo, TX

Carson County Library

Public Reading Room

Attn: Teri Keotting

P.O. Box 339

401 Main Street

Panhandle, TX 79060

Mae S. Bruce Public Library

Attn: Rose Holloway

P.O. Box 950

13302 6th Street

Santa Fe, TX 77510

Friendswood Public Library

Attn: Mary Perroni

$416 \mathrm{~S}$. Friendswood

Friendswood, TX 77546

Helen Hall Public Library

Attn: Shelly Leader

400 West Walker

League City, TX 88537

Houston Public Library

Attn: Carol Johnson

500 McKinney

Houston, TX 77002

La Marque Public Library

Attn: Greg Burns

1011 Bayou Road

La Marque, TX 77568

Genevieve Miller Public Library

Ms. Kathleen Brooks

8005 Barry Street

Hitchcock, TX 77563 
Moore Memorial Public Library

Attn: Joanne Turner

17019 th Avenue North

Texas City, TX 77590

Rosenberg Library

Attn: Jackie Kinsey

2310 Sealley Avenue

Galveston, TX 77550-2296

Portsmouth Public Library

601 Court Street

Portsmouth, Va 23704

Gonzaga University, Foley Center

Attn: Joyce Cox

East 502 Boone

Spokane, WA 99258

U.S. Department of Energy Reading Room Washington State University, Tri-Cities

Attn: Terri Traub

100 Sprout Road, Room 130

Richland, WA 99352

Department of Ecology

Washington State Nuclear \& Mixed Waste Library

Attn: Marilyn Smith

300 Desmond Drive

Lacey, WA 98503

U.S. Environmental Protection Agency

Attn: Karen Prater

1200 6th Avenue, HW-070

Seattle, WA 98101

Kitsap Regional Library

Attn: Tobey Gustafson

1301 Sylvan Way

Bremerton, WA 98310

Tacoma Public Library

Attn: Larry Mischo

1102 Tacoma Avenue South

Tacoma, WA 98402
University of Washington

Suzzallo Library

Attn: Hillary Reinert

Box 352900

Seattle, WA 98195

Westinghouse Hanford Company

Environmental Data Management Ctr

Attn: Debbie Isom

2440 Stevens Center Place, Room 1101

Richland, WA 99352

U.S. Department of Energy

Room 1E-190

Attn: Carolyn Lawson

1000 Independence Avenue, SW

Washington, DC 20585

Center for EM Information

470 L'Enfant Plaza East SW

Suite 7112

Attn: Kim Tulley

Washington, DC 20024

Wyoming State University

Supreme Court Building

Government Publication

Attn: Venice Beske

Cheyenne, WY 82002 